\title{
Konsument w działalności innowacyjnej przedsiębiorstw
}





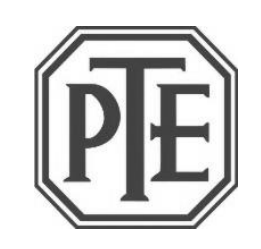

POLSKIE TOWARZYSTWO EKONOMICZNE

Kinga Karpińska, Anna Matel, Anna Protasiewicz

\section{Konsument w działalności innowacyjnej przedsiębiorstw}


Recenzent:

dr hab. Anna Gardocka-Jałowiec

Komitet Wydawniczy:

Adam Sadowski (przewodniczący)

Anna Dyhdalewicz

Luiza Kostecka-Tomaszewska

Mirosława Kozłowska-Burdziak

Adam Edward Szczepanowski

DOI 10.24136/eep.mon.2017.1

ISBN 978-83-917772-6-8

(C) Copyright by Polskie Towarzystwo Ekonomiczne

Białystok 2017

Polskie Towarzystwo Ekonomiczne Oddział w Białymstoku

15-062 Białystok, ul. Warszawska 63

http://pte.uwb.edu.pl, e-mail: pte@uwb.edu.pl

Korekta językowa:

Halina Lisicka

Opracowanie DTP:

Agencja EkoPress 


\section{Spis treści}

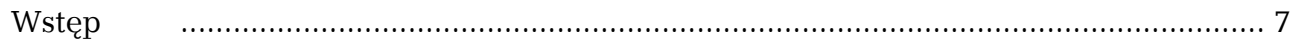

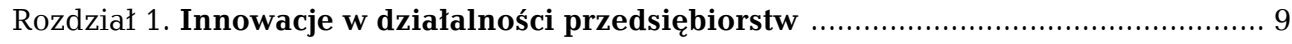

1.1. Definicja, źródła i rodzaje innowacji .................................................................. 9

1.2. Determinanty działalności innowacyjnej przedsiębiorstw.................................... 26

1.3. Bariery działalności innowacyjnej przedsiębiorstw ......................................... 32

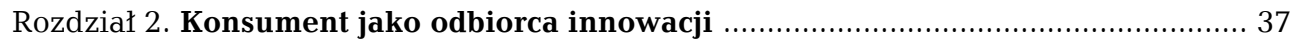

2 1. Konsumpcja i zachowania konsumentów jako kategorie ekonomiczne ................... 37

2.2. Proces akceptacji innowacji przez konsumentów ............................................. 49

2.3. Akceptacja innowacji w aspekcie determinant zachowań konsumentów................. 58

Rozdział 3. Zachowania konsumentów w procesie kreowania innowacji .................... 74

3.1. Miejsce konsumenta w procesie kreowania innowacji przez przedsiębiorstwa ....... 74

3.2. Trendy zachowań konsumentów w kreowaniu innowacji ................................... 86

3.3. Innowacje w kształtowaniu zachowań konsumentów ......................................... 99

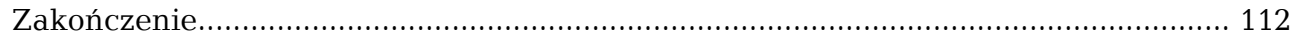

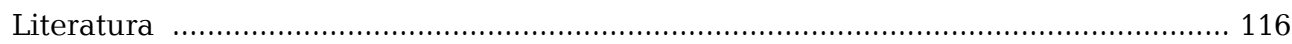

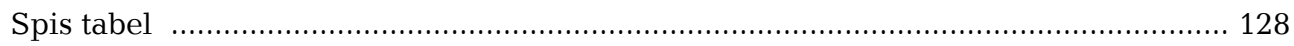

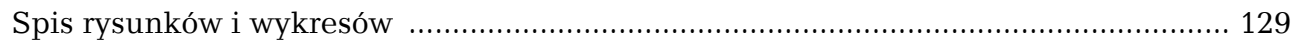





\section{Wstęp}

Współcześnie konsumpcja przestaje być jedynie środkiem do zaspokojenia potrzeb fizjologicznych. Staje się ona elementem ogólnie rozumianej kultury, a potrzeby, jakie zaspokaja, można zaliczyć do wszystkich poziomów potrzeb zgodnie z klasyfikacją przyjętą przez A. Maslowa. Jak zauważył M. Kempny: "obecnie nie tyle po prostu żyjemy w społeczeństwie konsumpcyjnym, ile stanowimy część cywilizacji konsumpcyjnej ze swoistą dla niej epistemologią" (Kempny 2005, s. 9). Procesy globalizacji i wirtualizacji powodują zmiany w zachowaniach konsumentów. Z drugiej strony ich potrzeby ewoluują, co wymusza zmiany w działalności innowacyjnej przedsiębiorstw.

Celem opracowania jest zatem próba analizy zależności między zachowaniami konsumentów a działalnością innowacyjną przedsiębiorstw. Zależności te są postrzegane jako interdyscyplinarny przedmiot badań podejmowanych przez specjalistów z różnych dziedzin, w tym: ekonomii, psychologii, socjologii, a także nauk o zarządzaniu. Niewątpliwie, jest to problematyka rozległa i wielowątkowa.

Zależności między konsumpcją a innowacją w literaturze najczęściej są analizowane przez pryzmat innowacyjności konsumpcji lub innowacji konsumenckich. W niniejszym opracowaniu podkreśla się, że zależność między zachowaniami konsumentów a działalnością innowacyjną przedsiębiorstw jest obustronna. Pojawienie się innowacji - zwłaszcza o charakterze pionierskim - wyznacza nowe kierunki zachowań konsumentów. Ze względu na charakter prowadzonych rozważań w prezentowanym opracowaniu przyjmuje się wąskie rozumienie pojęcia konsument, a mianowicie jako osoby biorącej udział w procesie decyzyjnym (nabywającej dobra i/lub usługi w celu zaspokojenia potrzeb oraz je użytkującej).

Dla współczesnego kształtu konsumpcji kluczową innowacją jest sieć internetowa. Następnie, kolejne innowacje pojawiają się w odpowiedzi na trendy zachowań konsumentów. Określają one kierunki rozwoju działalności innowacyjnej przedsiębiorstw. Zależności między zachowaniami konsumentów a działalnością innowacyjną nadal nie są do końca rozpoznane. Jak wskazała A. Gardocka-Jałowiec: „Wagę problemu podkreśla fakt, że podstawowy cel działalności innowacyjnej jest związany z głównym celem działal- 
ności gospodarczej - zaspokajaniem potrzeb ludzkich, mających służyć poprawie jakości życia. Zatem konsumpcja i działalność innowacyjna są aktywnościami ściśle ze sobą związanymi i nie są to zależności proste" (Gardocka-Jałowiec 2015a, s. 38).

Zależności między innowacjami a konsumpcją prowadzą więc do sformułowania szeregu pytań, w tym:

1) w jaki sposób przebiega proces akceptacji innowacji przez konsumentów?

2) jaką rolę w weryfikacji rynkowej innowacji odgrywają konsumenci-innowatorzy?

3) jakie funkcje gospodarcze pełni innowacyjność konsumentów?

4) od jakich czynników jest uzależniony stopień akceptacji innowacji przez konsumentów?

5) jaką rolę w działalności innowacyjnej przedsiębiorstw odgrywają konsumenci?

6) w jaki sposób przedsiębiorstwa mogą wykorzystać wiedzę o konsumentach w działalności innowacyjnej?

7) w jaki sposób innowacje wpływają na zachowania konsumentów?

Monografia składa się z trzech rozdziałów, które dotyczą z jednej strony innowacji i innowacyjności w działalności przedsiębiorstw (rozdział 1.), z drugiej konsumentów jako ich odbiorców, a więc ich decyzji konsumenckiej czy uwarunkowań jej podejmowania (rozdział 2.). Rozdział 3. jest z kolei próbą odpowiedzi na pytanie, w jaki sposób zachowania konsumentów oddziałują na innowacyjność przedsiębiorstw oraz jakie są tego przyczyny. W rozdziale tym podjęto próbę zobrazowania zwrotnej zależności między zachowaniami konsumentów a innowacjami. Wskazano, w jaki sposób innowacje wpływają na zachowania konsumentów, a także jak konsumenci weryfikują ofertę rynkową oraz w jaki sposób oddziałują na proces kreowania skutecznych innowacji. 


\section{Innowacje w działalności przedsiębiorstw}

\subsection{Definicja, źródła i rodzaje innowacji}

Problematyka innowacji wciąż jest przedmiotem licznych dyskusji. Wpływa na to fakt, że pojęcie innowacji jest bardzo obszerne i ujmuje zdarzenia o charakterze technicznym, organizacyjnym i finansowo-ekonomicznym. Za pioniera teorii innowacji uważa się J.A. Schumpetera, który przez innowację rozumiał wprowadzenie do produkcji wyrobów nowych lub też udoskonalenie produktów już istniejących, wdrożenie nowego czy udoskonalenie istniejącego procesu produkcyjnego, zastosowanie nowego sposobu sprzedaży bądź zakupów, otwarcie nowego rynku, wykorzystanie nowych surowców albo półfabrykatów oraz wprowadzenie nowej organizacji produkcji. W takim ujęciu innowacje są interpretowane jako nieciągłe przedsięwzięcia nowych kombinacji czynników wytwórczych (Schumpeter 1960, s. 104).

Pojęcie innowacji wywodzi się od łacińskiego słowa innovatio lub innovare, oznaczającego odnowienie, nowość, reformę. Innowacją można nazwać wszelkie zmiany (jakościowe, imitacyjne czy też kreatywne), które powstają w sferze materialnej i niematerialnej działalności przedsiębiorstw, a także cechują się oryginalnością lub nowością, zarówno dla przedsiębiorstw, jak i rynków lokalnych oraz zagranicznych, w których funkcjonują. Innowacja jest związana z każdą sferą życia społeczno-gospodarczego i można ją odnaleźć w nowych nurtach kulturalnych i myślowych.

W literaturze nie ma sformułowanej jednolitej definicji pojęcia innowacji, gdyż jest ona określana bardzo wąsko lub bardzo szeroko i wieloaspektowo, nie tylko na poziomie przedsiębiorstwa, ale również w skali gospodarki światowej. J.A. Schumpeter zwracił uwagę na to, że innowacja jest interpretowana bardzo szeroko i obejmuje nie tylko technikę produkcji, lecz także jej organizację i zbyt. Według autora, to właśnie dzięki innowacjom wprowadzanym przez przedsiębiorstwa, gospodarka nabiera dynamizmu, a one same generują wysokie zyski (Schumpeter 1960, s. 65).

W interpretacji pojęcia innowacji dominują dwa podejścia. W ujęciu pierwszym, innowacje to zmiany w sferze produkcji prowadzące do wytwo- 
rzenia nowych produktów. W drugim - innowacje to wszystkie procesy twórczego myślenia dążące do wykorzystania ulepszonych rozwiązań w: technice, technologii, organizacji, życiu społecznym (Pomykalski 2001, s. 17).

Problematyka innowacyjna dotyczy głównie pojęć i procesów innowacyjnych. W wąskim ujęciu, innowacja jest traktowana jako wynalazek, który ma określone wykorzystanie, natomiast w szerokim ujęciu jest to proces zarządzania, obejmujący różne czynności prowadzące do: tworzenia, rozwijania i wprowadzania nowych wartości w produktach lub nowych połączeń środków i zasobów, które są nowością dla tworzącej bądź wprowadzającej je jednostki (Niedzielski, Rychlik 2006, s. 21). Oprócz J.A. Schumpetera, innowacje szeroko także rozumieli: A.J. Herman, E. Hagen, J. Parker i P.R. Whitfield. Wąskie podejście do innowacji prezentowali: S. Kuznets, E. Mansfield oraz Ch. Freeman, którzy traktowali je jako pierwsze handlowe wprowadzenie nowego: produktu, procesu, systemu lub urządzenia (Janasz, Kozioł 2007, s. 14). Innowacyjność w niniejszej monografii jest rozpatrywana szeroko, tj. jako proces o dużym stopniu niepewności i złożoności, mało uporządkowany i podlagający zmianom, a przez swoją zmienność trudno mierzalny (Kline, Rosenberg 1986, s. 277).

Do polskich badaczy, zajmujących się problematyką innowacyjności jeszcze przed transformacją ustrojową, można zaliczyć: K. Wandelta, J. Czupiała, L. Piasecznego, J. Więckowskiego, B. Fiedora, S. Kasprzyka, L. Białonia, Z. Pietrusińskiego, W. Sprucha i Z. Madeja. Z kolei, w nowym systemie ekonomicznym (gospodarce rynkowej) autorami badań na temat innowacji byli: S. Marciniak, I.K. Hejduk, W.M. Grudzewski, A. Pomykalski, S. Gomułka, A.H. Jasiński, R.W. Ciborowski.

Na skutek zmiany systemu techniczno-ekonomicznego całej gospodarki, pod koniec XX wieku wzrosło zainteresowanie problematyką innowacyjności i klasyczne ujęcie schumpeterowskie zostało zastąpione nowszymi koncepcjami. Wraz ze zmniejszeniem się znaczenia przemysłu na rzecz usług, zakres przedmiotowy innowacji znacznie rozszerzył się i znalazł daleko poza sferą techniki (Janasz, Kozioł 2007, s. 13).

Współcześnie definiowanie innowacji wykracza poza innowacje technologiczne i uwzględnia również innowacje organizacyjne, np. wprowadzenie nowej techniki wytwarzania, która całkowicie zmienia organizację działu produkcyjnego. Podręcznik Oslo Manual wyróżnia zarazem innowacje marketingowe, które dotyczą: wdrażania nowych działań marketingowych, zmian w konstrukcji produktu, opakowania, promocji i dystrybucji, a także metod kształtowania cen oferowanych produktów i usług (Oslo Manual 2005a, s. 19). Wśród wyżej wymienionych rodzajów innowacji coraz częściej wyodrębnia się innowacje systemowe, określające zastosowanie nowego systemu, 
np. informatycznego. Niejednokrotnie innowacje te łączą się $\mathrm{z}$ organizacyjnymi i technicznymi, dlatego też mają charakter innowacji organizacyjno-technicznych.

Innowacja jest różnie postrzegana przez wielu autorów, a porównanie kilku definicji jednoznacznie wskazuje, że innowacje to wynik czegoś nowego, co powinno prowadzić do uzyskania korzyści zarówno przez przedsiębiorstwa, jak i całą gospodarkę (Białoń 2010, s. 14).

Tradycyjne podejście do innowacji wymaga od przedsiębiorstw wielu precyzyjnych i długotrwałych badań, w których każdy członek, znajdujący się w zespole badawczym, ma ściśle określony zakres zadań i odpowiedzialności. Ponadto, dynamiczne otoczenie, w którym funkcjonują przedsiębiorstwa, nasilająca się konkurencja i konwergencja branż, systematyczny i dynamiczny rozwój technologii (komunikacja i informatyzacja) umożliwiają budowanie coraz bardziej interaktywnych relacji między uczestnikami rynku, co powoduje konieczność angażowania coraz większej liczby uczestników w proces tworzenia innowacji. Zatem efekty tradycyjnego podejścia przestają odpowiadać potrzebom i oczekiwaniom odbiorców, przy tym nieefektywnie angażując coraz większe środki. Stąd obserwuje się narastające zainteresowanie przedsiębiorstw nowym podejściem do procesów innowacyjnych, tzw. innowacjami otwartymi (Mierzejewska 2008, s. 4).

Podejście otwarte intensywnie zaczęło rozwijać się w XXI wieku. Granicę wyznaczającą zmianę podejścia do procesów innowacyjnych opisał H.W. Chesbrough. W innowacjach otwartych najważniejszym elementem jest to, że przedsiębiorstwa nie mogą bazować tylko na własnych badaniach, ale powinny dzielić się zdobytą wiedzą i nabywać rozwiązania od innych organizacji. Ponadto, ważnym aspektem jest udostępnianie własnych, niewykorzystanych rozwiązań innym podmiotom na zasadzie sprzedaży licencji czy tworzenia podmiotów typu spin-off. Co więcej, istotnymi elementami tej koncepcji są: dialog, dostęp, ocena ryzyka i transparentność (Chesbrough 2002, s. 18).

W polskiej nauce koncepcję innowacji otwartych szczególnie akcentuje i bada A.H. Jasiński. Potraktował on scenę innowacji jako scenę teatralną, z aktorami pierwszoplanowymi i drugoplanowymi. Do pierwszoplanowych zaliczył naukę, przemysł i państwo, zaś do drugoplanowych - jednostki infrastruktury i transferu techniki. Kluczowy jest jednocześnie widz, czyli użytkownik innowacji w postaci konsumenta (Jasiński 2006, s. 29-33).

Innowacje są następstwem postępu naukowo-technicznego, także są ściśle związane z przedsiębiorczością, a ich wdrażanie jest obarczone wysokim stopniem ryzyka. Postęp techniczny jest determinowany przez kapitał ludzki i powstaje w wyniku działania jednostek w procesie gospodarowania (Tomczyk 2014a, s. 191). Przedsiębiorstwa, które chcą być innowacyjne, mu- 
szą tworzyć środowisko zdolne do komercjalizacji nowości, a więc do ich szybkiego wdrażania. Przedsiębiorstwo, generujące innowacje, zdobywające je i absorbujące, jak również docierające do informacji o rozwiązaniach innowacyjnych, nosi miano przedsiębiorstwa innowacyjnego (Bogdanienko 2004b, s. 59). Z kolei, metodologia OECD za przedsiębiorstwo innowacyjne uznaje taki podmiot gospodarczy, który wdrożył przynajmniej jedną innowację (produktową lub procesową) w określonym (najczęściej trzyletnim) okresie, równocześnie pod warunkiem że jest to dla niego nowość (Oslo Manual 2005b, s. 61).

Sukcesy przedsiębiorstw w coraz większym stopniu zależą dzisiaj od ich podatności na zmiany innowacyjne, ponieważ innowacje stają się wyznacznikiem rozwoju i pozycji rynkowej. Innowacje to zmiany przeprowadzane celowo, polegające na zmianie dotychczasowej pozycji na inną - ocenianą pozytywnie według przedsiębiorstwa, w efekcie końcowym składające się na jego rozwój i postęp w gospodarowaniu. Tworzenie innowacji odbywa się w ramach działalności innowacyjnej, zaś innowacja jest rezultatem procesu innowacyjnego. Jak napisał A.H. Jasiński: "firma jest kluczowym uczestnikiem procesu innowacyjnego, bowiem z jednej strony - zgłasza popyt na nowe rozwiązania naukowo-techniczne, a z drugiej - oferuje podaż innowacji technicznych. Współcześnie motorem postępu technicznego nie jest wbrew pozorom naukowiec, lecz innowacyjnie nastawiony przedsiębiorca" (Jasiński 2000, s. 15).

Reasumując, uporządkowanie definicji pojęcia innowacji w następstwie przysparza wielu problemów, z powodu wieloznaczności oraz trudności z określeniem obszaru porównań różnych ujęć. Z analizy literatury dotyczącej tego zagadnienia wynika, iż można wykazać cztery podstawowe sposoby tworzenia pojęcia innowacji, a mianowicie:

1) rzeczowy, traktujący innowację jako efekt końcowy lub wynik procesu;

2) wąski rzeczowy, odwołujący się do zastosowania określonej idei lub pomysłu w działalności innowacyjnej przedsiębiorstw;

3) wąski procesowy, obejmujący tylko fazę wprowadzania pomysłu innowacyjnego do praktyki;

4) szeroki procesowy, zawierający w sobie, oprócz wdrażania innowacji, również fazę powstawania i generowania pomysłu.

Analizując pojęcie innowacji, można dojść do wniosku, że odnosi się ono do wszystkich dziedzin życia człowieka, począwszy od gospodarki, a na społeczeństwie skończywszy. Dlatego też bywa ono odmiennie interpretowane przez poszczególnych autorów i badaczy, na co może wpływać długa tradycja badań nad innowacyjnością oraz odmienne ujęcia teoretyczne. Jak pisał P.F. Drucker: „nie ma możliwości przedstawienia jednej dokładnej 
i spójnej definicji innowacji. Można jedynie ustalać, kiedy, gdzie i jak szuka się w systematyczny sposób okazji do innowacji oraz w jaki sposób ocenia się szanse ich powodzenia oraz ryzyko, w przypadku niepowodzenia" (Drucker 1992, s. 43).

W literaturze wyodrębnia się wiele podziałów innowacji, wyróżniających je pod względem rozmaitych kryteriów, np. zakresu powodowanych zmian. W niniejszej monografii, celem zobrazowania różnorodności klasyfikacji innowacji, zostało przywołanych kilka z nich.

Klasyczny podział innowacji, opierający się na kryterium przedmiotowym, rozróżnia się:

1) produktowe, które mają miejsce, gdy na rynek wprowadza się nowy produkt lub produkt ulepszony;

2) procesowe, kiedy mamy do czynienia z zastosowaniem zmian w metodach wytwórczych;

3) organizacyjne, zmieniające sposób zarządzanie przedsiębiorstwem (Janasz, Kozioł 2007, s. 19-20).

Jak zauważył A.H. Jasiński (Jasiński 2012, s. 10), warto tutaj również uwzględnić innowacje usługowe. Usługi odgrywają coraz większą rolę w rozwoju gospodarczym. Innowacje usługowe charakteryzują się: niematerialnością, dużym udziałem czynnika ludzkiego oraz bezpośrednim kontaktem świadczącego usługę z klientem. Podział innowacji, zbliżony do przedstawionego powyżej, przyjęto w podręczniku Oslo (Oslo Manual 2008, s. 19, 49 i nast.). Wyróżnia się:

1) innowacje produktu;

2) innowacje procesu;

3) innowacje organizacyjne;

4) innowacje marketingowe.

Innowacja produktowa to wprowadzenie nowego produktu/usługi na rynek lub znaczne ulepszenie istniejących wyrobów (ujmuje się tu głównie zmiany cech funkcjonalnych). Innowacja procesowa to udoskonalenie albo wdrożenie nowej metody produkcji czy dostawy. Zalicza się do nich zmiany technologii, oprogramowania lub/i urządzeń. Innowacja organizacyjna z kolei to wdrożenie nowej metody organizacyjnej przez przedsiębiorstwo. Jej podstawowym celem jest redukcja kosztów bądź podwyższenie wydajności pracy. Natomiast innowacja marketingowa to wprowadzenie nowej metody marketingowej, niestosowanej dotychczas przez przedsiębiorstwo, w celu: poprawy efektywności zaspokojenia potrzeb klientów, otwarcia nowych rynków zbytu czy też zwiększenia sprzedaży.

Biorąc pod uwagę zakres zmian, wyodrębnia się innowacje: 
1) transformacyjne (przełomowe) - mają charakter strategiczny, są efektem prac badawczo-rozwojowych i mogą spowodować radykalną zmianę charakteru całych gałęzi gospodarki, np. telefon;

2) radykalne (wyróżniające się) - są związane z poprawą jakości i funkcjonowania określonych produktów, procesów technologicznych i mają istotne znaczenie $\mathrm{w}$ działalności bieżącej przedsiębiorstw, np. telefon komórkowy;

3) przyrostowe (narastające) - zmodernizowane produkty i technologie, które prowadzą do zmian charakteru przedsiębiorstw, np. telefon komórkowy z obiektywem fotograficznym (Kraśnicka, Ingram 2014, s. 20).

Ze względu na stopień oryginalności zmian można wyróżnić innowacje:

1) kreatywne - nowe produkty/procesy, które są wynikiem prac badawczorozwojowych i mają podstawowe znaczenie dla rozwoju przedsiębiorstw i gospodarki;

2) imitujące - powielanie lub odtwarzanie istniejących już wcześniej rozwiązań innowacyjnych w organizacjach;

3) pozorne - drobne zmiany wprowadzające w błąd użytkowników, którym sugeruje się pozornie nową ofertę; w rzeczywistości nie są to innowacje (Griffin 1996, s. 650).

Inne kryterium pozwala wyodrębnić innowacje twarde (technologiczne, związane z procesem wytwórczym i produktem) oraz miękkie (w obszarze organizacji, zarządzania i marketingu) (Markiewicz 2007, s. 11).

$\mathrm{Z}$ punktu widzenia przedsiębiorstwa przyjmuje się z kolei podział innowacji ze względu na:

1) zakres zmian w przedsiębiorstwie:

- $\quad$ innowacje jednostkowe - wywołują zmiany tylko w jednej dziedzinie przedsiębiorstwa;

- innowacje synergiczne - dotyczą zmian w wielu dziedzinach przedsiębiorstwa;

2) zakres zmian $w$ relacjach przedsiębiorstwo-otoczenie:

- $\quad$ innowacje autonomiczne - realizowane wyłącznie w ramach przedsiębiorstwa;

- innowacje systemowe - ich realizacja wymaga zmian w otoczeniu organizacji (Griffin 1996, s. 652).

Każda innowacja jest zmianą, natomiast nie każda zmiana jest innowacją. Rozpatrując rodzaje innowacji ze względu na ten atrybut wyróżnia się: zastosowanie w praktyce nowego produktu lub nowej metody produkcji, zdobycie i opanowanie nowego rynku zbytu albo nowych zasobów czy też powołanie do życia nowego przedsiębiorstwa bądź udoskonalenie struktur organizacyjnych (Schumpeter 1960, s. 104 i nast.). 
Natomiast Ch. Freeman wyróżnił:

- innowacje radykalne (ryzykowne), występujące bardzo rzadko, ale rewolucjonizujące sposób produkcji;

- $\quad$ innowacje usprawniające produkcję, mające charakter modernizacyjny (Freeman 1986, s. 103 i nast.).

Podobny podział innowacji przedstawił W. Bierfelder, rozróżniając innowacje podstawowe (będące odpowiednikiem innowacji radykalnych) oraz innowacje usprawniające (Bierfeleder 1981, s. 35, 36). Innowacje radykalne w swoich badaniach również uwzględnili J. Dąbrowski i I. Koładkiewicz, wyróżniając je pod względem charakteru zmian, jakie wywołują. Ponadto wyodrębnili oni:

- $\quad$ innowacje rekombinacyjne (usprawniające), polegające na wykorzystywaniu istniejących już w przedsiębiorstwie rozwiązań (np.: technicznych, organizacyjnych) do tworzenia nowych: produktów, systemów zarządzania czy technologii;

- $\quad$ innowacje modyfikacyjne, nieznacznie zmieniające: produkt, sposoby zarządzania i technologię, będące odpowiedzią na zaspokojenie potrzeb klientów przedsiębiorstwa (Dąbrowski, Koładkiewicz 1998, s. 140 i nast.).

S. Kline i N. Rosenberg odnieśli podział innowacji do procesu innowacyjnego i rozróżnili: innowacje radykalne oraz innowacje ewolucyjne (rekombinacyjne, usprawniające, udoskonalające), które mają zazwyczaj postać wzrostu wiedzy lub rozwoju technologii (Kline, Rosenberg 1986, s. 295 i nast.). Innowacje radykalne - stopniowe oraz techniczne i kierownicze - także wymienił w swojej książce R.W. Griffin. Radykalne w pełni zastępują dotychczasowe produkty, usługi bądź technologie, podczas gdy innowacje stopniowe tylko je udoskonalają i modyfikują. Innowacje techniczne to zmiany wyglądu produktu czy zmiana parametrów procesu, a innowacje kierownicze są to zmiany w procesie kierowania przedsiębiorstwem (Griffin 2001, s. 661 i nast.).

W. Janasz i K. Kozioł dokonali podziału innowacji ze względu na ich nowość w zakresie: światowym, kraju lub działu przemysłu oraz w skali przedsiębiorstwa (Janasz, Kozioł 2007, s. 20). Według kryterium zasięgu oddziaływania wyodrębnili oni innowacje wewnątrz przedsiębiorstwa i poza przedsiębiorstwem. Natomiast, według intensywności technologicznej i kapitałowej, wymienili innowacje „lekkie i ciężkie" o zaawansowanej technologii oraz „lekkie i ciężkie" o prostej technologii. Kolejnym kryterium podziału innowacji jest ich oryginalność - wyróżnia się tu kreatywne i imitujące. Kreatywne, zwane również pionierskimi, mają swoje odzwierciedlenie w odkryciach i wynalazkach, co powoduje, że nabierają istotnego znaczenia. Natomiast imitacyjne (adaptowane) to naśladownictwo i rozpowszechnianie ist- 
niejących już odkryć (Spruch 1976, s. 37). Biorąc pod uwagę horyzont czasowy, wyróżnia się innowacje strategiczne, o charakterze długoterminowym $\mathrm{i}$ istotnym znaczeniu dla przedsiębiorstw, a także innowacje taktyczne, dotyczące średniego, krótkiego lub bieżącego zasięgu czasu, ale mające wpływ na efektywność działań organizacji (Kalisiak 1975, s. 113).

W procesie tworzenia innowacji bardzo ważną rolę odgrywają: pracownicy, ich umiejętności, wiedza, osobowość, kwalifikacje. Uwzględniając te cechy, wskazuje się na innowacje:

1) technologiczne i techniczne, kiedy to technika i technologia wpływają na powstawanie innowacji;

2) ekonomiczno-organizacyjne, innowacje są tworzone przez przedsiębiorstwa;

3) społeczne i socjalno-bytowe, które są realizowane poza działalnością produkcyjną przedsiębiorstwa (Kotarba 1987, s. 7).

Pracowników, jako bardzo ważne ogniwo w powstawaniu innowacji, również uwzględnił F. Krzykała, który wymienił:

1) innowacje refleksyjne, świadomie realizowane przez pracowników w społecznym i technologicznym procesie produkcji;

2) innowacje bezrefleksyjne, wynikające ze społecznego i zawodowego doświadczenia pracowników; są realizowane, gdy wprowadzenie innowacji wydaję się oczywiste;

3) innowacje zamierzone (zaplanowane);

4) innowacje niezamierzone (spontaniczne), wprowadzane np. pod wpływem zasłyszanych opinii (Krzykała 1975, s. 27).

Miejscem, w którym najczęściej są tworzone innowacje, jest przedsiębiorstwo $^{1}$. Prowadzona przez nie działalność innowacyjna ma (przede wszystkim) prowadzić do rozwoju potencjału innowacyjnego, umożliwiającego: gromadzenie, wdrażanie i komercjalizację podjętych procesów innowacyjnych (Białoń 2010, s. 178). Współcześnie najważniejszym czynnikiem stymulującym innowacyjność podmiotów ekonomicznych jest kapitał intelektualny, czyli wiedza i ludzie, którzy ją posiadają. Innowacje wywołują wzrost sprawności procesu gospodarczego w wyniku obniżenia kosztów i pomnożenia efektów (Kozłowska 2016, s. 171).

Jednym z czynników wpływających na rodzaj wprowadzanych innowacji jest sektor, w którym działa przedsiębiorstwo. Niektóre z nich cechują się radykalnymi i gwałtownymi zmianami innowacyjnymi, inne zaś mniejszymi,

\footnotetext{
${ }^{1}$ Rozumie się przez nie zarobkową działalność: wytwórczą, budowlaną, handlową, usługową oraz poszukiwanie, rozpoznawanie i wydobywanie kopalin ze złóż, a także działalność zawodową wykonywaną w sposób zorganizowany i ciągły (art. 2 Ustawy z dnia 2 lipca 2004 r. o swobodzie działalności gospodarczej).
} 
przyrostowymi. Przedsiębiorstwa z sektorów charakteryzujących się wysokim i szybkim postępem technicznym są nastawione na: dynamiczne opracowywanie nowej idei i koncepcji produktu, wprowadzanie go na rynek oraz komercjalizację. Natomiast przedsiębiorstwa z innych sektorów mogą być nastawione głównie na innowacje organizacyjne po to, aby zaproponować konsumentowi produkt po cenie niższej niż konkurencja (Kalinowski 2010, s. 45).

Analizując rodzaje innowacji, nie sposób pominąć podział ze względu na korzyści, jakie przynoszą. Są to innowacje przynoszące: obniżkę kosztów, poprawę jakości wytwarzanych produktów, wzrost asortymentu lub ilości produktów, poprawę bezpieczeństwa i warunków pracy pracowników oraz chroniące środowisko (Baruk 2005, s. 32 i nast.).

Według innej koncepcji, innowacje dzieli się na: gospodarcze, społeczne, społeczno-gospodarcze, potencjalne i rzeczywiste (Kotarba 1987, s. 7).

Podsumowując zagadnienie rodzajów innowacji, trzeba wspomnieć, iż przedsiębiorstwa, które obecnie funkcjonują w konkurencyjnym środowisku, powinny stale inicjować i wdrażać różnego rodzaju innowacje, te z kolei mogą zabezpieczyć efektywność ich działań i ciągłego rozwoju. Innowacyjność powinna być atrybutem każdej organizacji, która chce rozwijać się, doskonalić i przetrwać. Oczywiście, największe znaczenie wśród wymienionych rodzajów innowacji mają te o charakterze radykalnym i przełomowym, jednak należy podkreślić, że każda (nawet najmniejsza) zmiana prowadząca do wzrostu efektywności jest korzystna.

Każda innowacja ma swoje źródło, czyli miejsce, w którym rodzi się nowy pomysł lub idea bądź pewne zjawisko przyczyniające się do powstania innowacji. Źródłem innowacji jest zarówno środowisko zewnętrzne, którego ciągła analiza pozwala na wprowadzanie zmian dostosowywanie ich do potrzeb otoczenia, jak i samo przedsiębiorstwo analizujące własne zasoby i potrzeby działań w obecnie bardzo burzliwym i zmieniającym się otoczeniu. Zatem źródłem innowacji jest wszystko to, co inspiruje człowieka do procesu zmian.

Nie istnieje jedno źródło innowacji, lecz jest wiele alternatyw korzystania z różnych zalążków urzeczywistniania zmian innowacyjnych. Bardzo rzadko można spotkać się z sytuacją, kiedy nowatorski pomysł jest dziełem przypadku - innowacje rzadko bywają dziełem samotnych geniuszy. Najlepsi nowatorzy to ludzie, którzy potrafią wykorzystać pomysł stosowany w jednym kontekście i zastosować go w nowatorski sposób w innym kontekście. Najlepsze przedsiębiorstwa na świecie nauczyły się stosować tę zasadę nie przypadkiem, ale w drodze systematycznego procesu (Janasz, Kozioł 2007, s. 27).

W literaturze przedmiotu wyróżnia się wiele różnorodnych podziałów źródeł innowacji. Najczęściej jest spotykany podział na źródła wewnętrzne 
i zewnętrzne. Źródła wewnętrzne (endogeniczne) można zlokalizować wewnątrz samego przedsiębiorstwa i są one związane z materialnymi i niematerialnymi zasobami, jakie ono posiada. Można tu przede wszystkim wyszczególnić własne zaplecze badawczo-rozwojowe przedsiębiorstwa, prawidłowe rozporządzanie zasobami i infrastrukturą, wiedzę i kreatywność pracowników, jak również umiejętności kadry kierowniczej do motywowania pracowników, spożytkowania ich zdolności twórczych czy też tworzenia atmosfery sprzyjającej powstawaniu innowacji. Korzystanie z wewnętrznych źródeł innowacji jest bardzo intratne dla organizacji, ponieważ pozwala zaangażować pracowników w funkcjonowanie przedsiębiorstwa, lecz także jest zdecydowanie tańsze od wykorzystywania źródeł zewnętrznych (Osęka, Wypijewski 1985, s. 53; Janasz, Kozioł 2007, s. 28; Zastempowski 2010, s. 73-74).

Bardzo popularną praktyką (ze względu na mniejsze ryzyko) jest stosowanie przez przedsiębiorstwa źródeł zewnętrznych (egzogenicznych). Częstotliwość korzystania z tych czynników najczęściej jest uzależniona od: rodzaju prowadzonej działalności gospodarczej, sytuacji finansowej, wielkości przedsiębiorstwa, charakteru otoczenia, w którym przedsiębiorstwo funkcjonuje, czy też od pozycji przedsiębiorstwa na rynku. Źródła zewnętrzne dzielą się na krajowe i zagraniczne (zob. rysunek 1.).

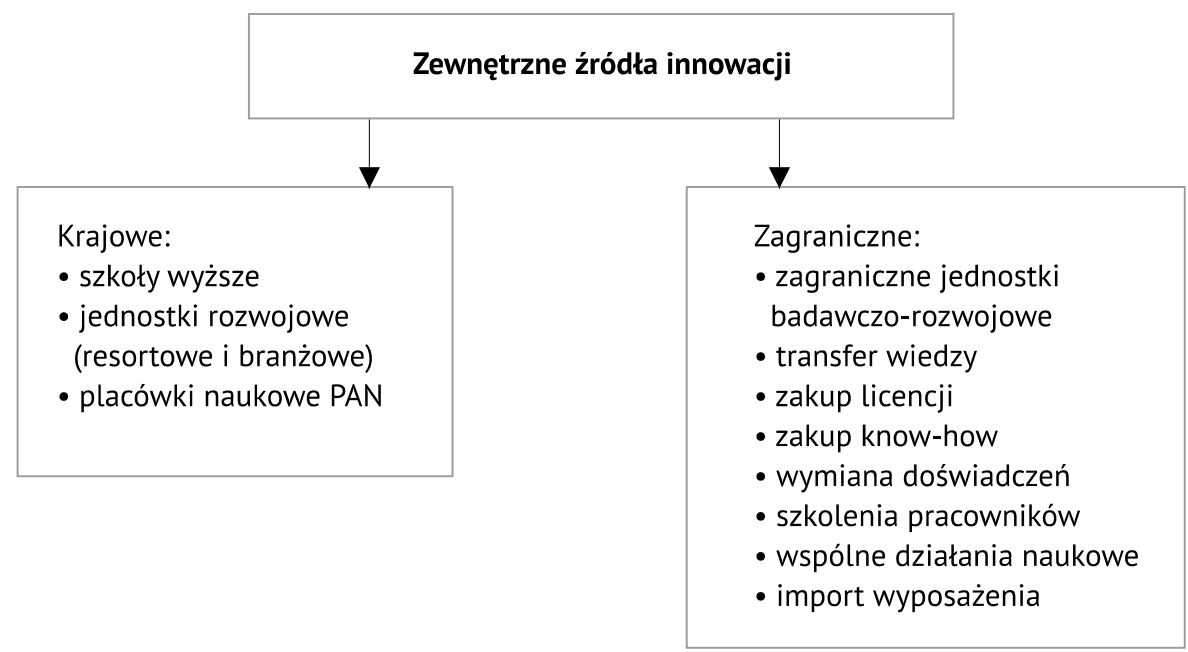

Rysunek 1. Podział zewnętrznych źródeł innowacji

Źródło: opracowanie własne na podstawie: Jasiński 2006, s. 18; Janasz 2003, s. 62 i nast.; Szatkowski 2001, s. 53 i nast.

Źródła innowacji można również podzielić na popytowe i podażowe, wskazane przez P.F. Druckera. Do źródeł popytowych zalicza się: 
1) niespodziewane zdarzenie - sukcesy i porażki innych podmiotów gospodarczych, nieprzydatne z punktu widzenia innych firm, które mogą okazać się impulsem do wdrożenia rozwiązań;

2) sprzeczność i rozdźwięk - wykorzystanie starych technologii w inny sposób lub nowe pomysły, których wdrożenie przynosi ład organizacyjny i obniżkę kosztów;

3) wymogi procesu - wynalazki zastosowane w jednej dziedzinie wymuszają ich wprowadzenie w innych;

4) zmiany rynku lub branży - okazja do długotrwałego i niezagrożonego działania;

5) zmiany demograficzne - zmiany potrzeb społecznych i indywidualnych;

6) zmiany w sposobie myślenia - wynikają z luki między stanem faktycznym a wyobrażeniem o nim (Drucker 2004, s. 58).

Z kolei, do źródeł podażowych Drucker zaliczył nową wiedzę, czyli innowacje oparte na nowej wiedzy, tzw. innowacje przełomowe (Drucker 1992, s. 43).

W literaturze przedmiotu są analizowane dwa podejścia do pojęcia samej innowacyjności. Rozważane jest ono jako jednowymiarowe zjawisko oznaczające zdolność osoby/grupy do wytworzenia i skutecznego zastosowania nowych pomysłów bądź też jako zdolność przedsiębiorstwa do ciągłego poszukiwania, zastosowania $\mathrm{w}$ praktyce $\mathrm{i}$ rozpowszechniania innowacji, która prowadzi do wzrostu jego nowoczesności oraz umocnienia pozycji konkurencyjnej na rynku, a także jako pomyślne wprowadzenie nowej rzeczy albo metody do praktyki. Na tym tle definicję innowacyjności bardzo często odnosi się do:

1. zmian technologicznych, gdzie innowacyjność jest definiowana jako predyspozycje do ich przyswajania (Kitchell 1995, s. 195 i nast.), możliwości rozwijania nowych technologii (Gopalakrishnan 2000, s. 137-153) czy też zdolność do podejmowania działań wykraczających poza obecny stan wiedzy (Kimberly, Evanisko 1981, s. 589 i nast.);

2. zmian behawioralnych, gdzie innowacyjność jest utożsamiana z szybkością adaptacji do zmian oraz z możliwością tworzenia nowych pomysłów i otwartości na zmiany (Stalk, Evans, Shulamnan 1992, s. 59 i nast.; Hurley, Hult 1998, s. 42 i nast.);

3. skłonności do zmian w obszarze produkcji i tworzenia wyrobów lub świadczenia usług (Foxall 1984, s. 35).

Innowacyjność jest również definiowana jako zjawisko wielowymiarowe. Oznacza predyspozycje i pozytywne nastawienie do kreowania i zastosowania w praktyce zmian w każdej dziedzinie życia społeczno-gospodarczego (Baruk 2006, s. 9) oraz zdolności przedsiębiorstwa do zajmowania się no- 
wymi pomysłami i wchodzenia w nowe projekty - idee czy wynalazki - których wynikiem są nowe produkty i usługi. Innowacyjność przedsiębiorstwa to także wdrożenie przez nie nowego rozwiązania w dziedzinie organizacji i zarządzania, technologii lub marketingu (Rogoda 2005, s. 17). Dotyczy ona wszystkich podmiotów gospodarczych, które mają możliwość prowadzenia badań rozwojowych, skutecznie opracowują nowe idee wytwarzania/ udoskonalania procesów, produktów bądź usług, a zarazem są zdolne zastosować je w praktyce (Lumpkin, Dess 1996, s. 135 i nast.). Można tutaj równocześnie określić innowacyjność przedsiębiorstwa jako udoskonalanie i rozwijanie technologii eksploatacyjnych i produkcyjnych, dotyczących: usług, sfery organizacji i zarządzania, oraz zbieranie, przetwarzanie i udostępnianie informacji (Założenia polityki innowacyjnej 1994, s. 15).

Aby przedsiębiorstwa mogły efektywnie wprowadzać i komercjalizować innowacje na rynkach krajowych i zagranicznych, muszą w swojej działalności stosować zasadę celowej innowacji oraz zarządzanie i strategie przedsiębiorcze, bowiem innowacja jest narzędziem przedsiębiorczości (Kwieciński, Moszkowicz, Sroka 2007, s. 11). Innowacyjność powinna być cechą każdego przedsiębiorstwa, gdyż na rynku konkurencyjne są te podmioty gospodarcze, które mają znaczny udział w działalności innowacyjnej i wykorzystują wszystkie mechanizmy rynkowe. Współczesne przedsiębiorstwo powinno być: innowacyjne, otwarte na nowości, zdolne do wyszukiwania sygnałów z rynku i gotowe do wprowadzania zmian innowacyjnych. Nierozerwalnie wiąże się to z rozwijaniem swojej innowacyjności poprzez profesjonalne i kompetentne zarządzanie oraz tworzenie takich warunków pracy, które będą dla ludzi interesujące i atrakcyjne (Barczak, Walas-Trębacz 2007, s. 14). Innowacyjność jest jedną z jego cech konkurencyjności, charakteryzującą się: poszukiwaniem, kreowaniem i wdrażaniem różnego rodzaju innowacji; umiejętnością podejmowania decyzji w sytuacji ryzyka czy niepewności; zdolnością ciągłej obserwacji rynku, wychwytywania z niego sygnałów i szybkiej reakcji na pojawiające się na rynku potrzeby; umiejętnością obserwowania i przewidywania działań konkurencji czy też przełamywaniem inercji innowacyjnej. Wraz z pojawieniem się innowacyjności rośnie zatem konkurencyjność przedsiębiorstwa.

Współcześnie innowacyjność jest dla przedsiębiorstwa jednym z kluczowych czynników wpływających na jego konkurencyjność, stąd można skonstatować, że jest jednym z warunków decydujących o przetrwaniu i rozwoju. Wymaga ona nie tylko tzw. instrumentalnej racjonalności (Penc 1999, s. 13), a więc oceny i analizy zmian wdrażanych w przedsiębiorstwie, ale również tzw. przezorności strategicznej (Bratnicki 1998, s. 88), czyli rozwijania działań przedsiębiorczych, zwiększenia zdolności podejmowania wyzwań czy 
rozwiązywania problemów oraz podejmowania nowych wyzwań rynkowych dających pozytywne efekty w przyszłości. Przedsiębiorstwa mogą stać się innowacyjne zarówno wskutek dokonywania przełomowych odkryć i wynalazków, jak i dzięki drobnym ulepszeniom, modyfikacjom bądź poprawkom. O ile pierwsza droga jest trudna, skomplikowana i zdarza się rzadko, o tyle druga bardzo często znajduje się "w zasięgu ręki" przedsiębiorstw, jedynie muszą one umieć z niej skorzystać. Zatem innowacyjność powinna stać się podstawowym sposobem istnienia i funkcjonowania przedsiębiorstwa. Wszyscy pracownicy powinni zaś znać jej wartość i rozpoznawać tkwiące w niej możliwości. Jednocześnie innowacyjność ma być dla przedsiębiorstwa podstawową siłą oryginalności, pomysłowości i twórczości, na stałe wpisaną w zarządzanie i kulturę organizacyjną.

Zmierzając do innowacji, wiele przedsiębiorstw na całym świecie współpracuje ze szkołami wyższymi albo rozwija własne działy badawcze. Niekiedy w rolę przedsiębiorców wchodzą także sami naukowcy. Choć tzw. modele systemów innowacyjnych z biegiem czasu ewoluują, to kluczowa pozycja biznesu w działalności innowacyjnej wydaje się pozostawać uniwersalnie stała.

W literaturze przedmiotu wyróżnia się wiele modeli procesów innowacyjnych. Przez mechanizm innowacji rozumie się ciągłe zmiany ilościowe i jakościowe czynników produkcji. Najstarszym i najprostszym mechanizmem, pochodzącym z połowy lat trzydziestych XX wieku, jest model liniowy, który bazuje na założeniu, że wszystkie idee innowacyjne mają swoje źródło $\mathrm{w}$ sferze $\mathrm{B}+\mathrm{R}$. Model ten występuje $\mathrm{w}$ dwóch odmianach, $\mathrm{tj} .:$ popytowej i podażowej. Pierwsza, podażowa, oparta na neoklasycznej teorii wzrostu (technology-push), wywodzi się z koncepcji innowacji J. Schumpetera (rysunek 2.).

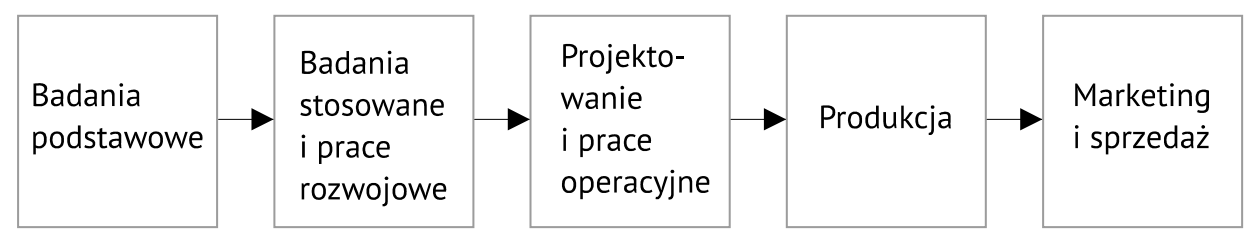

Rysunek 2. Podażowy model liniowy innowacji („pchany przez naukę”)

Źródło: Weresa 2014, s. 32.

Badania podstawowe to oryginalne prace badawcze, eksperymentalne lub teoretyczne, podejmowane przede wszystkim w celu zdobywania nowej 
wiedzy o podstawach zjawisk i obserwowalnych faktów, bez nastawienia na bezpośrednie zastosowanie komercyjne. Z kolei, badania stosowane to prace badawcze podejmowane w celu zdobycia nowej wiedzy, zorientowane przede wszystkim na praktykę.

Prace rozwojowe to: nabywanie, łączenie, kształtowanie i wykorzystywanie dostępnej aktualnie wiedzy i umiejętności z dziedziny nauki, technologii i działalności gospodarczej, a także innej wiedzy i umiejętności do planowania produkcji oraz tworzenia i projektowania nowych, zmienionych bądź ulepszonych produktów, procesów i usług. Wyłącza się z tego katalogu prace obejmujące rutynowe i okresowe zmiany wprowadzane do: produktów, linii produkcyjnych, procesów wytwórczych, istniejących usług oraz innych operacji w toku, nawet jeżeli takie zmiany mają charakter ulepszeń (art. 1, ust. 3 Ustawy z dnia 15 stycznia 2015 roku o zmianie ustawy o zasadach finansowania nauki oraz niektórych innych ustaw).

Źródłem innowacji w zaprezentowanym modelu są wyniki prac naukowo-badawczych, prowadzonych na uczelniach wyższych i w instytutach badawczych. Cały proces innowacyjny zaczyna się od wyników badań podstawowych, które są przedmiotem dalszych badań stosowanych i prac rozwojowych. Następnie przedsiębiorstwo podejmuje prace projektowe i operacyjne w celu uruchomienia produkcji. Ostatnim etapem są działania marketingowe i sprzedaż produktu.

Koncepcja podażowa pozwala na ocenę zmian innowacyjnych za pomocą produktywności czynności produkcji, których wzrost jest konsekwencją wykorzystania innowacji albo zmian technologicznych. Innowacje są wynikiem możliwości technicznych, zaś zmiany produktywności czynników są związane ze wzrostem lub spadkiem innowacyjności. W skali mikroekonomicznej podejście to oznacza, że inicjatorem działalności innowacyjnej jest kadra B+R. Przedsiębiorstwa z większym zapleczem badawczo-rozwojowym mają większą szansę na wykorzystanie efektów swoich prac do celów gospodarczych, zyskując tym samym przewagę nad konkurencją. Z kolei, zakładając podobny potencjał badawczy, aktywność innowacyjna będzie zawsze wydatniejsza w tych dziedzinach, które charakteryzują się szybszym rozwojem bazy naukowej (badania podstawowe) (Ciborowski 2012, s. 49-50).

Model podażowy intensywnie rozwijał się w latach 1950-1965, kiedy następował szybki rozwój przemysłu i technologii, co miało swoje odzwierciedlenie w polityce publicznej skoncentrowanej na podaży. Nacisk położono na stymulowanie badań i rozwoju oraz zapewnienie określonego poziomu wykwalifikowanej siły roboczej (Weresa 2014, s. 34). 
Inną wersją modelu liniowego jest model popytowy, wynikający z założeń ekonomii keynesowskiej (demand-pull). Graficzną prezentację tego modelu przedstawia rysunek 3.

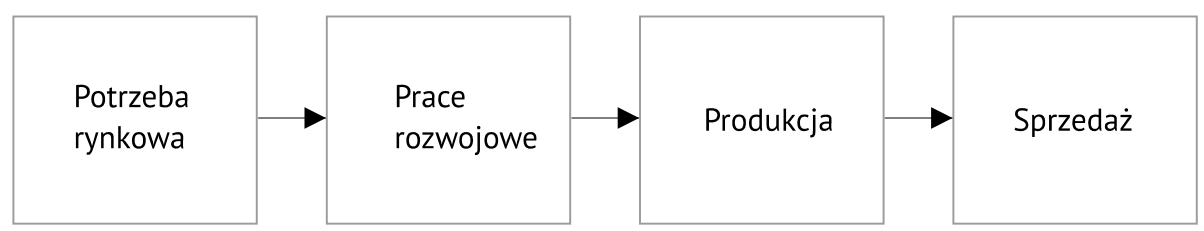

Rysunek 3. Popytowy model liniowy innowacji („ciągnięty przez rynek”)

Źródło: Weresa 2014, s. 34.

Model popytowy wykształcił się w latach sześćdziesiątych i siedemdziesiątych XX wieku. W tym okresie przedsiębiorstwa koncentrowały się na wprowadzaniu nowych produktów, głównie na bazie istniejących technologii. Rosnąca konkurencja na rynku zwiększyła rolę marketingu w polityce każdego przedsiębiorstwa. W tym modelu istotne znaczenie miała zatem kadra zajmująca się marketingiem, której zadaniem było rozpoznawanie potrzeb rynkowych. Realizacja tych potrzeb często wiązała się z wprowadzaniem innowacji, które pozwalały osiągnąć przewagę rynkową wdrażającym je podmiotom.

Tabela 1. Popytowa i podażowa koncepcja innowacji

\begin{tabular}{l|l|l}
\hline \multicolumn{1}{c|}{ Kryterium } & \multicolumn{1}{c}{ Popytowa } & \multicolumn{1}{c}{ Podażowa } \\
\hline $\begin{array}{l}\text { nowe rozwiązania } \\
\text { techniczne }\end{array}$ & $\begin{array}{l}\text { gtównie tworzone na wyraźne } \\
\text { zapotrzebowanie rynkowe }\end{array}$ & $\begin{array}{l}\text { przede wszystkim generowane } \\
\text { do opatentowania }\end{array}$ \\
\hline $\begin{array}{l}\text { czas wdrożenia nowego } \\
\text { rozwiązania }\end{array}$ & szybki & powolny \\
\hline $\begin{array}{l}\text { znaczenie efektów } \\
\text { ekonomicznych }\end{array}$ & podstawowe, rozstrzygające & $\begin{array}{l}\text { dla celów ewidencyjnych } \\
\text { i opatentowania }\end{array}$ \\
\hline $\begin{array}{l}\text { stosowanie rachunku } \\
\text { ekonomicznego }\end{array}$ & pełne & marginalne \\
\hline $\begin{array}{l}\text { postęp techniczny } \\
\text { bodźce do twórczości } \\
\text { technicznej }\end{array}$ & wynika z potrzeb rynkowych & zrealizowany przypadkowo \\
\hline $\begin{array}{l}\text { ukierunkowanie działalności } \\
\text { twórczej }\end{array}$ & silne i materialne & spełnienie aspiracji twórczych \\
\hline $\begin{array}{l}\text { udział twórców } \\
\text { we wdrożeniu }\end{array}$ & aktywny & oderwanie od popytu \\
\hline \begin{tabular}{l} 
reprezentanci koncepcji \\
\hline
\end{tabular} & Schmookler & brak \\
\hline
\end{tabular}

Źródło: Białoń 2010, s. 29. 
Istnieje wiele przykładów innowacji technicznych związanych z podejściem popytowym (wzrost zapotrzebowania na samochody spowodował wzrost wykorzystania napędu mechanicznego) oraz podażowym (energia atomowa) (Ciborowski 2012, s. 52). Jednak oba modele mają charakter liniowy, zatem we współczesnej gospodarce, zwłaszcza w krajach wysoko rozwiniętych, są już nieaktualne. Różnice między popytową a podażową koncepcją procesu innowacyjnego zaprezentowano w tabeli 1.

$\mathrm{Na}$ początku lat osiemdziesiątych ubiegłego wieku wykształcił się kolejny model innowacji, zwany interaktywnym (sprzężeniowym). Złożoność powiązań między uczestnikami procesu innowacyjnego $\mathrm{w}$ tym modelu zaprezentowano na rysunku 4.

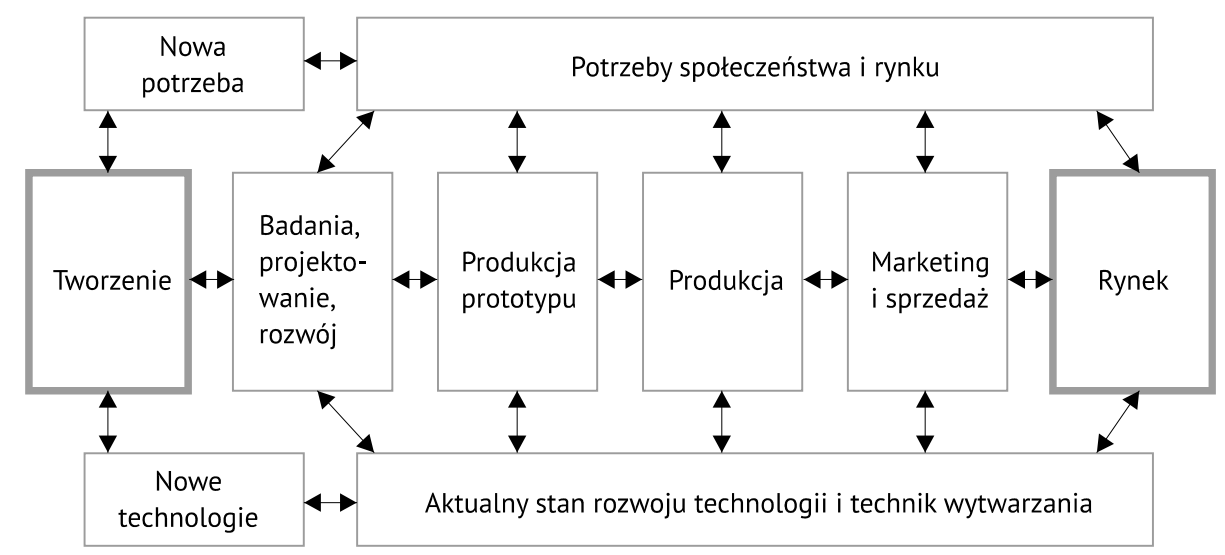

Rysunek 4. Model interaktywny procesów innowacyjnych

Źródło: Rothwell 1994, s. 10.

W zaprezentowanym modelu innowacja jest traktowana jako proces, który dzieli się na ciąg faz odrębnych funkcjonalnie, ale sprzężonych i współzależnych. Istotą tego procesu jest umiejętne połączenie możliwości technicznych przedsiębiorstwa i aktualnych potrzeb rynkowych.

W latach osiemdziesiątych i dziewięćdziesiątych XX wieku pojawił się kolejny model innowacji, tzw. zintegrowany. Bazuje on na interakcjach zachodzących między rynkiem a nauką. Kluczowe znaczenie w tym modelu ma współpraca inżynierów i menedżerów, której efektem są innowacje wypracowane $\mathrm{w}$ zespole. Ważnym aspektem jest zaprojektowanie z nastawieniem na realne możliwości produkcyjne.

Na przełomie XX i XXI wieku ukształtował się model sieciowy procesów innowacyjnych, który charakteryzuje się rosnącą rolą współpracy między 
różnymi podmiotami a organizacjami. Wysokie znaczenie ma dostęp do sieci zasobów, a nie samo ich posiadanie (Weresa 2014, s. 42).

Na początku XXI wieku wzrosło znaczenie pozyskiwania i wykorzystania wiedzy zewnętrznej, co wpłynęło na ukształtowanie się kolejnego modelu - innowacji otwartych. Stanowił on połączenie wiedzy wewnętrznej (własnej) przedsiębiorstwa i wiedzy zewnętrznej. Tego typu sprzężenia wiązały się ze zwiększoną rolą kooperacji między różnymi organizacjami (Ciborowski 2012, S. 58).

Niezależnie od wykorzystywanego modelu procesu innowacyjnego, zawsze muszą zaistnieć następujące fazy:

1) sprecyzowanie idei innowacyjnej i jej ocena z ekonomicznego, technicznego i marketingowego punktu widzenia;

2) przygotowanie najlepszej idei innowacyjnej do wdrożenia;

3) wdrożenie (Weresa 2014, s. 48).

Poszczególne podejścia do procesów innowacyjnych ewoluowały, co przede wszystkim wynikało ze zróżnicowania czynników i działań tworzących innowacje. Można wyodrębnić elementy odzwierciedlające zróżnicowanie mechanizmów innowacji:

- wpływ zmian technologicznych, które przebiegały w różnych kierunkach i na rozmaitych poziomach;

- $\quad$ istota zmian jest różna na każdym poziomie w miarę upływu czasu;

- $\quad$ zmianie mogą również ulegać podmioty, które korzystają z innowacji (Białoń 2010, s. 35).

Jednak celem każdego z tych modeli niezmiennie pozostaje opracowanie i wdrożenie nowych lub istotnie ulepszonych produktów i procesów. $Z$ racji na podejmowane zagadnienie najistotniejsze jest uchwycenie zmian technologicznych zawartych w produktach i procesach.

Modele procesów innowacyjnych można także podzielić na zamknięte i otwarte. Do drugiej połowy XX wieku dominowały te pierwsze (tradycyjny model). Według modelu tradycyjnego, proces innowacyjny jest oparty na własnych zasobach, które są ściśle chronione przed konkurencją, co z kolei wymaga dużych nakładów na działalność badawczo-rozwojową. Zatem działalność innowacyjna była głównie dostępna dla dużych i stabilnych finansowo organizacji. H.W. Chesbrough zdefiniował kilka najważniejszych zasad, które odnoszą się do innowacji zamkniętych:

- $\quad$ przedsiębiorstwo zatrudnia najlepszych specjalistów, pracowników z danego sektora;

- $\quad$ pracownicy kreują i rozwijają nowe pomysły;

- przedsiębiorstwo, które samo generuje i wprowadza innowacje, może osiągnąć pierwszeństwo na rynku; 
- $\quad$ podmiot, który pierwszy wprowadza innowację na rynku, zwykle wygrywa;

- $\quad$ przedsiębiorstwo może przeznaczać więcej środków inwestycyjnych na działalność B+R, co spowodowuje największą kumulację najlepszych pomysłów, a w konsekwencji może to doprowadzić do osiągnięcia pozycji lidera na rynku;

- $\quad$ podmiot powinien mieć kontrolę nad własnością intelektualną, aby konkurencja nie czerpała zysków z jego pomysłów (Chesbrough 2003, s. 15).

Modele procesów innowacyjnych w przedsiębiorstwie mogą opierać się na różnych koncepcjach, jednak wszystkie łączą wspólne cechy, takie jak: otwartość i współpraca. natomiast cechy te wywołują ryzyko, niepewność i kosztowność innowacji.

\subsection{Determinanty działalności innowacyjnej przedsiębiorstw}

Działalność innowacyjna podmiotów gospodarczych jest uwarunkowana wieloma czynnikami i determinantami. Można je rozpatrywać w skali makro, mezo i mikro, co zaprezentowano w tabeli 2.

Tabela 2. Podział czynników wpływających na aktywność innowacyjną przedsiębiorstw

\begin{tabular}{|c|c|c|}
\hline $\begin{array}{c}\text { Czynniki } \\
\text { makroekonomiczne }\end{array}$ & $\begin{array}{c}\text { Czynniki } \\
\text { mezoekonomiczne }\end{array}$ & $\begin{array}{c}\text { Czynniki } \\
\text { mikroekonomiczne }\end{array}$ \\
\hline $\begin{array}{l}\text { - system podatkowy } \\
\text { - polityka kredytowa } \\
\text { - prawo o ochronie środo- } \\
\text { wiska } \\
\text { - wsparcie rządu } \\
\text { - infrastruktura wspierająca } \\
\text { biznes }\end{array}$ & $\begin{array}{l}\text { - konkurencja firm zagra- } \\
\text { nicznych } \\
\text { - koszty wdrożeń } \\
\text { - ryzyko wdrożeń } \\
\text { - cechy rynku }\end{array}$ & $\begin{array}{l}\text { - rodzaj strategii firmy } \\
\text { - siły i słabości firmy } \\
\text { - kwalifikacje pracowników } \\
\text { i właściciela } \\
\text { - bodźce ekonomiczne dla pracowników } \\
\text { - park maszynowy } \\
\text { - środki finansowe } \\
\text { - wyniki ekonomiczno-finansowe firmy } \\
\text { - badanie rynku } \\
\text { - informacje o nowościach } \\
\text { - wielkość firmy } \\
\text { - wzrost firmy } \\
\text { - kierunek działalności firmy } \\
\text { - długość funkcjonowania firmy na } \\
\text { rynku }\end{array}$ \\
\hline
\end{tabular}

Źródło: Mizgajska 2002, s. 49. 
Podstawowym powodem podejmowania działalności innowacyjnej jest potrzeba wdrożenia innowacji. Potrzeba ta może wynikać z wielu przyczyn, najczęstsze z nich zostały zaprezentowane na rysunku 5.

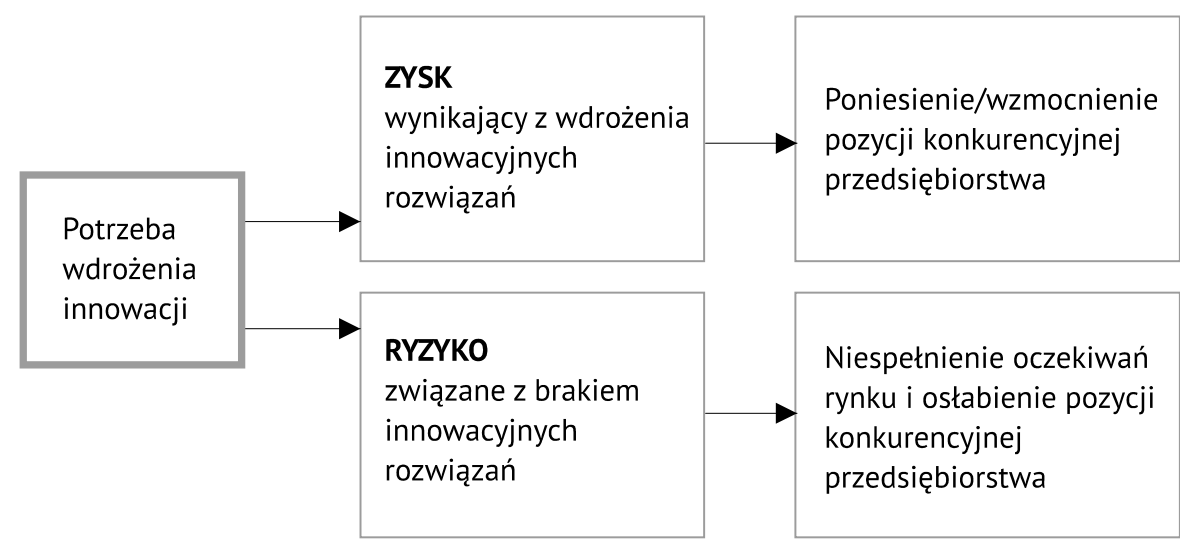

Rysunek 5. Potrzeby wprowadzenia innowacji

Źródło: Rychlik 2007, s. 33.

Determinanty działalności innowacyjnej przedsiębiorstw można również podzielić na zewnętrzne (niezależne od podmiotu) i wewnętrzne (związane z podmiotem gospodarczym i tkwiące w nim). Źródła wewnętrzne (endogeniczne) można zlokalizować wewnątrz samego przedsiębiorstwa i są one związane z materialnymi i niematerialnymi zasobami, jakie ono posiada. Można tu przede wszystkim wyszczególnić: siłę finansową, wyczucie rynku, wielkość przedsiębiorstwa, ciągłość kierownictwa, gotowość i motywację kadry kierowniczej do podejmowania ryzyka, wysokość progu wejścia na rynek. Do czynników zewnętrznych (egzogenicznych) zalicza się: konkurencję na rynku, tendencję wzrostową rynku, tempo postępu technicznego, koniunkturę, wpływ państwa na gospodarkę, synergię branżową związaną z wyborem wprowadzania innowacji (Francik, Pocztowski 1991, s. 27).

Z kolei, determinanty wewnętrzne procesów innowacyjnych w przedsiębiorstwie przedstawiono na rysunku 6.

Przez potencjał finansowy przedsiębiorstwa rozumie się jako środki własne oraz środki oferowane przez instytucje finansowe i pozafinansowe. natomiast potencjał ludzki odnosi się do: liczby zatrudnionych, ich struktury, wykształcenia, kwalifikacji i doświadczenia. Potencjał rzeczowy oznacza: strukturę aparatu produkcyjnego, jego elastyczność, długość użytkowania oraz poziom mechanizacji. Ostatnia determinanta - wiedza i informacje techniczne - odnoszą się głównie głównie wiąże się z umiejętnością pozyskiwania informacji rynkowych i korzystania z nadarzających się szans. 


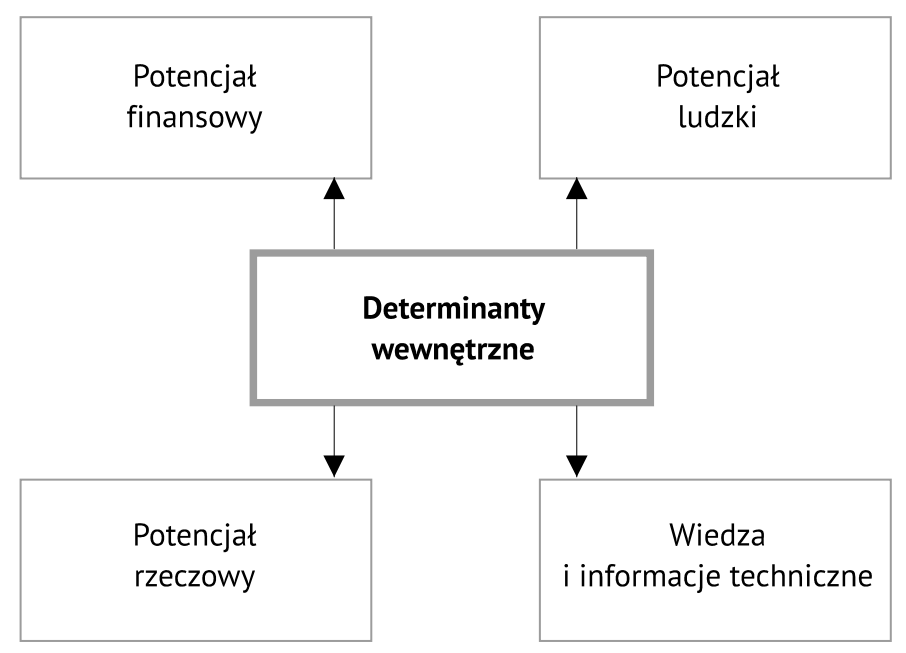

Rysunek 6. Determinanty wewnętrzne procesów innowacyjnych w przedsiębiorstwie Źródło: Poznańska 1998, s. 40-41.

Innowacje często są kojarzone z postępem i nowoczesnością, a ich dyfuzja do sfery realnej w dużej mierze przyczynia się do rozwoju podmiotów gospodarczych. Stanowią one najważniejszą siłę napędową rozwoju przedsiębiorstw, są bowiem specyficznymi narzędziami przedsiębiorczości, wyrażającej się w ciągłym poszukiwaniu nowych koncepcji czynników wytwórCzych, a zatem będącej motorem postępu technicznego (Penc 1995, s. 63).

Szczegółowa analiza determinant potencjału innowacyjnego przedsiębiorstwa jest przedmiotem licznych badań. Kompleksową koncepcję czynników potencjału innowacyjnego zaproponował Danny Samson, wyróżniając: strategię, przywództwo, zmiany, orientację na klienta, proinnowacyjną kulturę organizacyjną, alianse wiedzy, jakość procesów, uczenie się, innowacyjną orientację HR (Gloet, Samson 2013, s. 2). Natomiast Joe Tidd, John Bessant i Keith Pavitt skoncentrowali się na wewnątrzorganizacyjnych stymulatorach procesów innowacyjnych, zaliczając do najważniejszych: wizyjne przywództwo, odpowiednią strukturę organizacyjną, rekrutację, chęć zaangażowania w proces innowacyjny, umiejętność prowadzenia pracy grupowej oraz gotowość do uczenia się i adaptowania nowych rozwiązań (Tidd, Bessant, Pavit 2002, s. 33).

Potencjał innowacyjny jest determinowany przez wewnętrzny potencjał innowacyjny i dostęp do zewnętrznych źródeł innowacji. Na wewnętrzny potencjał innowacyjny składa się: kadra (jej wiedza i doświadczenie, umiejętności i kwalifikacje oraz sposób zarządzania dostępnymi zasobami, zarządzanie informacją), badania i rozwój (wyodrębnione komórki $\mathrm{B}+\mathrm{R}$, prowa- 
dzone prace $B+R$, prace zlecone itp.), jak również technologia (komputery i technologia ICT, maszyny i urządzenia oraz stopień nowoczesności maszyn i urządzeń). Zewnętrzne źródła innowacji to przede wszystkim wyższe uczelnie i jednostki badawczo-rozwojowe, a także firmy konkurencyjne czy odbiorcy/ dostawcy (Żołnierski 2005, s. 15).

W zakończeniu krótkiej prezentacji kwestii zdolności innowacyjnej warto podkreślić główne znaczenie wiedzy w jej tworzeniu. Zdolność innowacyjną przedsiębiorstwa przede wszystkim stanowi: wiedza zgromadzona przez firmę w trakcie organizacyjnego uczenia się; wiedza z zakresu rozmyślnego tworzenia pozwalająca na skuteczne wykorzystanie potencjału innowacyjnego (zasobów) w jego działalności innowacyjnej; wiedza ujęta we wzorce i pragmatykę gospodarczą, będąca zasadniczym czynnikiem sprawczym postępu i korzystnych zmian. W świetle powyższych uwag można sformułować zasadę logicznego następstwa procesów organizacyjnego uczenia się w aspekcie osiągania stanu wysokiej zdolności innowacyjnej, na co za tym idzie, innowacyjności. Organizacyjne uczenie się jest procesem z udziałem informacji i wiedzy, które prowadzi do zmiany zasobów wiedzy i może służyć zmianie zachowań ludzi oraz generować zdolności innowacyjne organizacji, tym samym osiągając stan wysokiej innowacyjności.

We współczesnej gospodarce, która cechuje się zmiennością i nieprzewidywalnością, czynnikiem przyczyniającym się do rozwoju przedsiębiorstw, poza zasobami kapitału i pracy, staje się umiejętność pozyskiwania oraz przetwarzania wiedzy i informacji. Na znaczeniu szczególnie zyskuje innowacyjność. Innowacje zwiększają konkurencyjność danego podmiotu zwłaszcza względem krajowych przedsiębiorstw. Dzięki temu, pozostałe przedsiębiorstwa są skłonne do podejmowania działań innowacyjnych, wzmacniając jednocześnie pozycję konkurencyjną kraju na arenie międzynarodowej (Osęka, Wypijewski 1985, s. 49).

Innowacje umożliwiają:

1) lepsze przystosowanie przedsiębiorstwa do otoczenia;

2) podniesienie jakości wyrobów i konkurencyjności ich sprzedaży;

3) zlikwidowanie barier i aktywizację zasobów przez zwiększenie ogólnej sprawności i efektywności działania;

4) usprawnienie organizacji i metod pracy;

5) poprawę warunków bezpieczeństwa pracy;

6) substytucję pracy żywej w następstwie lepszej organizacji i wyższej wydajności, opartej na bogatszym i bardziej nowoczesnym wyposażeniu technicznym;

7) zwiększenie zdolności eksportowych (Grudzewski, Hejduk 2001, s. 48). 
Innowacje, które dostarczają nowych wartości klientom, zazwyczaj przejawiają się w postaci nowych: produktów, technologii, idei, podejść, a także systemów. Klienci przywiązują się do przedsiębiorstwa i na podstawie pozytywnych doświadczeń gwarantują stały popyt, a tym samym wysoką rentowność przedsiębiorstwa (Kotler 1994, s. 20).

Przedsiębiorstwa, aby uzyskać skuteczną przewagę konkurencyjną, powinny starać się wyprzedzać innych w szukaniu wszystkiego, co nowatorskie oraz trudne do skopiowania. Wyłącznie podmioty, które systematycznie wzmacniają swoją pozycję konkurencyjną, będą w stanie utrzymać się na rynku. Przewagę konkurencyjną głównie osiągnąć można w wyniku ciągłego podnoszenia poziomu innowacyjności i uzyskiwania dzięki temu odpowiedniej efektywności (Knap-Stefaniuk 2007, s. 14-16).

W. Grodzieński i I. Hejduk podkreślili w swoich pracach, że za sprawą innowacji (zwłaszcza technicznych) następuje: poprawa i unowocześnienie procesów wytwórczych, podniesienie efektywności, wydajności i jakości pracy, wzrost jakości wyrobów i ich konkurencyjności na rynku, zwiększenie ogólnej sprawności i efektywności działania. Zmiany w produktach i procesach wytwarzania produktów przyczyniają się do wzrostu jakości lub obniżenia kosztów. Stąd pozycja konkurencyjna przedsiębiorstwa, które wprowadza zmiany, jest wyższa (Grudzewski, Hejduk 2001, s. 451-452).

Innowacje powodujące obniżenie jednostkowych kosztów bezpośrednich wytwarzania produktów lub kosztów stałych przedsiębiorstwa, również mogą przynieść wzrost bieżącej lub przyszłej konkurencyjności. Bieżąca konkurencyjność wzrośnie, ponieważ przedsiębiorstwo, antycypując wzrost sprzedaży, może obniżyć cenę w ten sposób, aby zachować wartości uzyskiwanych dotychczas wskaźników rentowności sprzedaży, majątku i kapitałów własnych. Obniżona cena skutkuje wzrostem atrakcyjności oferty przedsiębiorstwa (przy zachowaniu jakości dotychczas oferowanych produktów) i powoduje wzrost udziału w rynku, a także wzrost wielkości nadwyżki finansowej.

Innowacje odgrywają istotną rolę w kształtowaniu przewagi konkurencyjnej przedsiębiorstwa. Trwałą przewagę konkurencyjną może ono uzyskać, gdy w dziedzinie, w której działa, zdobędzie kluczowe kompetencje, czyli umiejętności w zakresie techniki i technologii wyróżniające je na tle innych przedsiębiorstw oraz umożliwiające wdrażanie nowych technologii i wytwarzanie konkurencyjnych wyrobów.

Aktywność przedsiębiorstw w zakresie podejmowania przedsięwzięć innowacyjnych jest zdeterminowana wewnętrznymi i zewnętrznymi czynnikami ich innowacyjności. Według I. Bielskiego, decyzje dotyczące aktywności innowacyjnej są kształtowane przez: czynniki zewnętrzne pozostające 
poza wpływem przedsiębiorstwa, czynniki zewnętrzne w ograniczonym stopniu przez nie kształtowane oraz czynniki wewnętrzne (Bielski 2005, s. 10).

Wielu autorów wyodrębniło szereg klasyfikacji zewnętrznych determinant innowacyjności przedsiębiorstw. Na przykład M. Kolarz wyróżnił następujące zewnętrzne czynniki innowacyjności:

- $\quad$ prowadzenie prac $B+R$ poza samym przedsiębiorstwem;

- $\quad$ wspólne prace $B+R$ z podmiotami zewnętrznymi;

- $\quad$ zlecanie prac $B+R$ podmiotom zewnętrznym, staże i praktyki zawodowe poza firmą, zatrudnienie obcych pracowników;

- $\quad$ wymiana wiedzy technicznej;

- zlecanie produkcji, koprodukcja;

- budowa kompletnych obiektów poza przedsiębiorstwem;

- $\quad$ świadczenie usług na rzecz podmiotu obcego lub przez podmiot obcy (kontrakty menedżerskie, umowy franchisingowe);

- handel zagraniczny;

- $\quad$ eksport i import licencji;

- $\quad$ tworzenie wspólnych przedsiębiorstw oraz podejmowanie zagranicznych inwestycji bezpośrednich (Kolarz 2006, s. 57).

Z kolei, S. Rychtowski do zewnętrznych uwarunkowań innowacyjności przedsiębiorstw zaliczył:

- $\quad$ procesy usługowe obejmujące system badań naukowych oraz system informacji naukowo-technicznej, ekonomicznej i organizacyjnej;

- $\quad$ klimat społeczno-polityczny;

- $\quad$ normy prawne i nakazy administracyjne (polityka innowacyjna państwa);

- warunki ogólnorynkowe - mechanizm rynkowy, rachunek ekonomiczny, ceny;

- $\quad$ system edukacji i szkoleń,

- $\quad$ powiązania rynkowe i pozarynkowe z partnerami będącymi źródłem informacji i technologii;

- $\quad$ infrastrukturę techniczną (Rychtowski 2004, s. 589).

Do grupy czynników wewnętrznych (endogenicznych) należą:

- $\quad$ siła finansową przedsiębiorstwa;

- wyczucie rynku;

- nakłady własne przedsiębiorstwa na prace $B+R$;

- $\quad$ nakłady własne przedsiębiorstwa na innowacje;

- liczba i kwalifikacje kadr, umiejętności i doświadczenia badawcze, produkcyjne i marketingowe oraz skuteczność systemów informacji, komunikacji i motywacji w przedsiębiorstwie;

- $\quad$ wielkość przedsiębiorstwa;

- $\quad$ ciągłość kierownictwa przedsiębiorstwa; 
- gotowość i motywację kadry kierowniczej do podejmowania ryzyka;

- $\quad$ wysokość progu wejścia na rynek (Francik, Pocztowski 1991, s. 27).

Zaprezentowana w paragrafie lista uwarunkowań działalności innowacyjnej przedsiębiorstw nie wyczerpuje tematu. Wyraźnie jest zarysowany podział na czynniki zewnętrzne wobec przedsiębiorstwa i zależące od jego potencjału wewnętrznego. O ile przedsiębiorstwo może mieć (i często ma) wpływ na kształtowanie wewnętrznego potencjału innowacyjnego przedsiębiorstwa, o tyle ten wpływ w odniesieniu do zewnętrznych uwarunkowań jest znikomy lub wręcz żaden. Przedstawione wyrywkowo czynniki pokazują ich intensywność i wielokierunkowość oddziaływania. Mają one szerszy charakter, dlatego ich wpływ na innowacyjność przedsiębiorstw jest zagadnieniem niezwykle trudnym i złożonym.

\subsection{Bariery działalności innowacyjnej przedsiębiorstw}

Pozyskiwanie, zastosowanie oraz wdrażanie innowacji jest związane z pojawianiem się barier, które mogą zostać zdefiniowane jako okoliczności opóźniające, hamujące lub modyfikujące proces generowania i implementacji innowacji (Mirow, Hoelzle, Gemuenden 2008, s. 9). Każdy innowator spotyka się z dwoma podstawowymi barierami działania. Pierwszą z nich jest bariera myśli, która zamyka się w pytaniu: „co zrobić, aby w efekcie doprowadzić do powstania nowatorskiego rozwiązania?" - oczywiście z wymiernymi wynikami ekonomicznymi. Drugą barierą jest wdrożenie już opracowanej innowacji, a w następnej kolejności rozpowszechnienie jej oraz uzyskanie korzyści (Jodłowska 2010, s. 565). Bariery te powodują utrudnienia w działalności innowacyjnej, gdyż opóźniają projekty innowacyjne, zmuszają przedsiębiorstwa do przerwania bądź zaprzestania przedsięwzięć innowacyjnych. Bariery wpływające na działalność innowacyjną przedsiębiorstw, które oddziałują przedstawia tabela 3. 
Tabela 3. Bariery wpływające na działalność innowacyjną przedsiębiorstw

\begin{tabular}{|c|c|}
\hline Bariery & Składniki \\
\hline $\begin{array}{l}\text { Bariery ekonomiczne, } \\
\text { finansowe, kosztowe }\end{array}$ & $\begin{array}{l}\text { wysokie koszty innowacji, wysokie oprocentowanie kredytów, brak własnych } \\
\text { środków finansowych przedsiębiorstw, brak instrumentów finansowo-zabez- } \\
\text { pieczających ułatwiających pozyskanie tych zasobów, polityka fiskalna rządu, } \\
\text { wysokie składki na ubezpieczenie społeczne, wysokie podatki }\end{array}$ \\
\hline Bariery rynkowe & $\begin{array}{l}\text { regionalne zróżnicowanie popytu, wrażliwość przedsiębiorstw na spadek popytu } \\
\text { lokalnego, wysoka konkurencja na rynku, niepewność popytu na innowacje }\end{array}$ \\
\hline Bariery informacyjne & $\begin{array}{l}\text { ograniczony dostęp do danych i informacji oraz skomplikowana ich wymiana, } \\
\text { niski stopień dostępu do informacji o przedsiębiorstwach na danym terenie, } \\
\text { brak informacji o możliwościach innowacyjnych przedsiębiorstwa, zły prze- } \\
\text { pływ informacji przez kanały komunikacyjne w przedsiębiorstwie }\end{array}$ \\
\hline Bariery społeczne & $\begin{array}{l}\text { inercja innowacyjna, pesymistyczne nastawienie do powodzenia innowacji, } \\
\text { bezrobocie, kojarzenie innowacyjności z nieuczciwymi praktykami przedsię- } \\
\text { biorczymi, niekorzystna demografia, niska kultura przedsiębiorczości }\end{array}$ \\
\hline Bariery naukowe & $\begin{array}{l}\text { niski poziom współpracy z uczelniami wyższymi, jednostkami badawczo-roz- } \\
\text { wojowymi w kraju i za granicą, słabe tempo wdrażania wyników prac B+R, } \\
\text { inercyjne podejście do wyników prac badawczych i rozwojowych }\end{array}$ \\
\hline $\begin{array}{l}\text { Bariery związane } \\
\text { z produkcją }\end{array}$ & $\begin{array}{l}\text { przestarzałe wyposażenie, niskie moce produkcyjne, brak wykwalifikowanej } \\
\text { kadry }\end{array}$ \\
\hline Bariery techniczne & $\begin{array}{l}\text { przestarzała aparatura i wyposażenie techniczne, niski popyt na rynku na inno- } \\
\text { wacje technologiczne, duże koszty zlecania wykonania opracowań technicz- } \\
\text { nych }\end{array}$ \\
\hline $\begin{array}{l}\text { Bariery związane } \\
\text { z polityką rządu, } \\
\text { bariery prawne }\end{array}$ & $\begin{array}{l}\text { zmienność przepisów prawa, niejednoznaczne regulacje prawa gospodar- } \\
\text { czego, nieprecyzyjne zasady polityki regionalnej i lokalnej, ograniczenia } \\
\text { samorządów lokalnych, nieznajomość przepisów unijnych, skomplikowane } \\
\text { procedury zakładania i prowadzenia działalności gospodarczej }\end{array}$ \\
\hline $\begin{array}{l}\text { Bariery } \\
\text { czasoprzestrzenne }\end{array}$ & $\begin{array}{l}\text { długotrwałe utrzymywanie się gospodarki centralnie planowanej, niski lub } \\
\text { niewykorzystany potencjał geograficzny }\end{array}$ \\
\hline Bariery naturalne & $\begin{array}{l}\text { zanieczyszczenie środowiska, brak naturalnych zasobów (ropa naftowa, gaz } \\
\text { ziemny) }\end{array}$ \\
\hline Bariery instytucjonalne & $\begin{array}{l}\text { niski poziom wykorzystywania unijnych funduszy pomocowych, niska wiedza } \\
\text { o patentach, niekonsekwentna realizacja długoterminowej strategii innowa- } \\
\text { cyjności }\end{array}$ \\
\hline Bariery zarządzania & $\begin{array}{l}\text { brak skłonności do uczenia się, nieznajomość technik zarządzania, małe umie- } \\
\text { jętności w wykorzystywaniu informacji z otoczenia }\end{array}$ \\
\hline Bariery edukacyjne & $\begin{array}{l}\text { słaby dostęp do informacji gospodarczej, niski stopień wykorzystania Inter- } \\
\text { netu }\end{array}$ \\
\hline $\begin{array}{l}\text { Bariery kadrowe / } \\
\text { dotyczące wiedzy }\end{array}$ & $\begin{array}{l}\text { brak wykwalifikowanej kadry, niskie kwalifikacje pracowników, wysoka fluk- } \\
\text { tuacja pracowników }\end{array}$ \\
\hline
\end{tabular}

Źródło: Włodarczyk 2007, s. 110-111; Strużycki, Bojewska 2011, s. 22 i nast.; Oslo Manual

2005b, s. 118; Poznańska 1998, s. 57; Dzierżanowski, Sztetyło 2000, s. 36. 
Mimo powstawania całej sieci instytucji wspierania rozwoju innowacyjności w polskich przedsiębiorstwach, nadal istnieje wiele barier utrudniających jej rozwój. Największe znaczenie ma ogólny stan gospodarki, który nie generuje mechanizmów wpierających wchłanianie innowacji przez przedsiębiorstwa. Ograniczający jest także popyt rynkowy, niewyzwalający zapotrzebowania na produkty zaawansowane technologicznie. Zasadniczo, przeszkody ograniczające prowadzenie działalności innowacyjnej można podzielić na:

1) zewnętrzne: podażowe (problemy z uzyskaniem informacji, zasobów lub nakładów finansowych), popytowe (ryzyko innowacji, ograniczenia rynkowe, utrudnienia związane z identyfikacją potrzeb nabywców) oraz środowiskowe (powiązane z otoczeniem, np. ograniczenia rządowe);

2) wewnętrzne: dotyczące zasobów przedsiębiorstwa, np.: brak środków finansowych, kultury organizacji, wykwalifikowanej kadry oraz dotyczące człowieka i jego osobowości, czyli obawa przed ryzykiem, inercja innowacyjna (Baruk 2002, s. 54 i nast.).

K. Janasz wymienił następujące przeszkody w rozwoju innowacyjności:

1) niski poziom zatrudnienia w sektorze gospodarki, będący "nośnikiem gospodarki opartej na wiedzy" (przemysł lotniczy, kosmiczny, komputerowy itd.);

2) niedobór środków finansowych na innowacje;

3) słaba współpraca naukowo-techniczna środowisk gospodarczych i naukowych;

4) niski poziom wdrożeń nowych technologii;

5) mała liczba specjalistów przygotowanych do wdrażania strategii innowacyjnych;

6) niedostateczna współpraca z: sektorem badawczo-rozwojowym, otoczeniem biznesowym, podmiotami o zbliżonym profilu produkcji w kraju i za granicą oraz jednostkami samorządowymi i lokalnymi organizacjami;

7) skomplikowane procedury patentowe (Janasz 2009, s. 36).

Według badań Głównego Urzędu Statystycznego, w roku 2015 wciąż głównym źródłem finansowania nakładów na działalność innowacyjną były środki własne przedsiębiorstw (62\% wszystkich poniesionych na ten cel nakładów przedsiębiorstw przemysłowych i 73\% usługowych). W latach 20132015 publiczne wsparcie finansowe działalności innowacyjnej otrzymało 27,9\% aktywnych innowacyjnie przedsiębiorstw przemysłowych $(29,4 \%$ w latach 2011-2013) oraz 19,8\% - usługowych (wcześniej 21,2\%). Wsparcie ze źródeł publicznych stymuluje wydatkowanie środków ze źródeł własnych podmiotów w kolejnych okresach. Co piąte aktywne innowacyjnie przedsiębiorstwo przemysłowe oraz co siódme usługowe w latach 2013-2015 otrzymało pub- 
liczne wsparcie finansowe z Unii Europejskiej. Przedsiębiorstwa przemysłowe, które uzyskały wsparcie finansowe od instytucji krajowych, w większym stopniu korzystały ze środków z jednostek szczebla centralnego niż lokalnego, natomiast w przedsiębiorstwach usługowych odnotowano taki sam udział środków z zarówno jednostek szczebla centralnego, jak i lokalnego (GUS 2016, s. 94-97).

W zakresie współpracy także wyniki polskich przedsiębiorstw nie są satysfakcjonujące. W latach 2013-2015 w ramach działalności innowacyjnej współpracowało jedynie 29,1\% aktywnych innowacyjnie przedsiębiorstw przemysłowych (30,1\% w latach 2012-2014) oraz 24,4\% przedsiębiorstw usługowych (wcześniej 24,6\%). Współpracę w obszarze działalności innowacyjnej głównie podejmowały przedsiębiorstwa przemysłowe należące do działu "Produkcja wyrobów farmaceutycznych" (51,5\%), a w usługach - podmioty z działu "Badania naukowe i prace rozwojowe" (64,8\%). W zakresie współpracy w działalności innowacyjnej największa $(21,2 \%)$ część przedsiębiorstw przemysłowych najwyżej oceniała współpracę ze szkołami wyższym. Podobny odsetek przedsiębiorstw współpracował z różnego rodzaju dostawcami $(20,7 \%)$ i przedsiębiorstwami z tej samej grupy przedsiębiorstw $(19,8 \%)$. Inaczej współpracę z różnymi instytucjami partnerskim oceniały przedsiębiorstwa usługowe. Największa część tych przedsiębiorstw za najbardziej korzystną uznawała współpracę z innymi przedsiębiorstwami tej samej grupy (35,5\%) oraz z różnymi dostawcami $(25,6 \%)$, tj. znaczenie więcej niż z instytucjami badawczymi (11,7\%). Natomiast zarówno w przemyśle, jak i w usługach nastąpił wzrost udziału współpracujących przedsiębiorstw w ramach inicjatywy klastrowej w ogólnej liczbie podmiotów współpracujących w zakresie działalności innowacyjnej (do 19,2\% oraz 20,8\% podmiotów). Wciąż również niewiele przedsiębiorstw decydowało się na ochronę swojej własności przemysłowej w Urzędzie Patentowym Rzeczypospolitej Polskiej, a mianowicie: w latach 2013-2015 3,0\% przedsiębiorstw przemysłowych oraz 3,2\% usługowych dokonało zgłoszeń znaków towarowych, zaś wzorów użytkowych odpowiednio: 1,0\% i 0,3\% (GUS 2016, s. 94-116).

Działalność innowacyjna jest związana z wprowadzaniem zmian, dlatego napotyka na pewną bezwładność i niechęć ze strony samego przedsiębiorstwa oraz pracujących w niej ludzi. Cechą charakterystyczną tych przedsiębiorstw jest inercja aktywna, czyli skłonność do działania według wcześniejszych wzorców nawet wtedy, gdy konieczna jest odpowiedź na zmiany otoczenia. Opór wobec zmian może mieć zarazem postać: inercji przyzwyczajeń, która charakteryzuje się niezmiennym praktykowaniem sprawdzonych wcześniej metod czy przełamywaniem barier psychologicznych; inercji kinetycznej, tzn. małej podatności na zmiany, małej elastyczności przedsię- 
biorstwa, małej zdolności i szybkości reagowania na zmiany oraz inercji intuicji, czyli intuicyjnych działań na podstawie "fachowej" oceny sytuacji. Inercja innowacyjna uwidacznia się w działaniach zarówno kierownictwa, jak i pracowników. Polega ona m.in. na: unikaniu odpowiedzialności, małej otwartości na wiedzę, uchylaniu się od podejmowania trudnych decyzji i realizowania skomplikowanych zadań, przybieraniu postaw roszczeniowych czy też starzeniu się intelektualnym kierownictwa oraz dogmatyzacji poglądów (Penc 1999, s. 261-282). Z punktu widzenia wzrostu przedsiębiorczości podmiotów istotnymi uwarunkowaniami zewnętrznymi, a co za tym idzie innowacyjności wykazywanej przez przedsiębiorstwa, są zatem także szeroko rozumiane uwarunkowania instytucjonalne (Tomczyk 2014b, s. 56-60).

Podsumowując, bariery działalności innowacyjnej występują zarówno w otoczeniu przedsiębiorstw, jak i w ich wnętrzu. Większość badań dotyczących czynników ograniczających lub spowalniających działalność innowacyjną przedsiębiorstw zawiera jedynie katalog barier utworzonych według różnych kryteriów i nieprzyporządkowanych do wywołujących je przyczyn. Występowanie barier wskazuje jednak na konieczność prowadzenia polityki proinnowacyjnej, przychylnej dla przedsiębiorstw poszukujących innowacji, a także dla tych, które je wdrażają.

Wśród barier ograniczających działalność innowacyjną przedsiębiorstw autorki szczególną uwagę zwracają na niepewny popyt. Bardzo ważną rolę odgrywają bowiem czynniki o charakterze rynkowym związane ze zróżnicowaniem popytu czy jego identyfikacją przez przedsiębiorstwo. Dopiero odpowiednie rozpoznanie zachowań konsumenckich i reakcja na nie pozwalają na efektywne wdrażanie innowacji. 


\section{ROZDZIAŁ 2. \\ Konsument jako odbiorca innowacji}

\subsection{Konsumpcja i zachowania konsumentów jako kategorie ekonomiczne}

Słowo konsumpcja wywodzi się od łacińskiego consumptio i oznacza „jedzenie, spożywanie, użytkowanie dóbr". W literaturze przez konsumpcję w szerokim ujęciu rozumie się jako „zużywanie zasobów w celu zaspokojenia potrzeb w powtarzalnych, bezpośrednich aktach spożycia" (Janoś-Kresło 2006, s. 62). Istotnym elementem wskazanej definicji jest dążenie do zaspokajania potrzeb w wyniku aktów konsumpcji. Kolejny element definicji to powtarzalność aktów konsumpcji, co wydaje się dyskusyjne, istnieje bowiem znaczna grupa dóbr, które człowiek nabywa raz w życiu. Przykładem może być konsumpcja części usług medycznych. Wielu konsumentów jednokrotnie nabywa nieruchomość mieszkalną, co wiąże się z ograniczeniem budżetowym. Dotyczy to także dóbr, które konsument nabył, lecz ze względu na niski stan satysfakcji pozakupowej nie ponawia tego aktu.

Z drugiej strony zdecydowana większość potrzeb ma charakter odnawialny. Przykładem są potrzeby związane z: żywieniem, zakupem ubrań, korzystaniem z informacji. Wydaje się jednak, że odnawialność nie powinna być wyznacznikiem definiowania pojęcia konsumpcji. Tym samym na znaczeniu zyskuje konsumpcja pojęta jako zaspokajanie potrzeb konsumenckich w bezpośrednich aktach spożycia.

Konsumpcja w literaturze najczęściej jest definiowana w trzech ujęciach: jako akt społeczny, proces społeczny oraz sfera reprodukcji społecznej (Bywalec, Rudnicki 2002, s. 9-10). W pierwszym wymiarze pod uwagę są brane konkretne zachowania nabywcze. Konsumpcja przyjmuje postać aktu zaspokajania danej potrzeby, która zazwyczaj - choć jak wskazano nie zawsze - ma charakter odnawialny.

Ze względu na odnawialność większości potrzeb konsumpcyjnych, w praktyce konsumpcja przyjmuje formę procesu społecznego. Na takie znaczenie wskazał J. Szczepański, według którego o konsumpcji należy mówić jako o: "zachowaniach jednostek i zbiorowości, polegających na uświadomieniu i ocenie własnych potrzeb, uznaniu ich wagi i decyzjach ich zaspokojenia; zachowaniach zmierzających do wyboru i uzyskiwania środków ich 
zaspokojenia, obchodzenia się ze zdobytymi środkami oraz ich spożywania" (Szczepański 1981, s. 134). Interpretowanie konsumpcji jako procesu wydaje się formalnie poprawne, ale znaczeniowo problematyczne, trudno bowiem odróżnić pojęcia: konsumpcji i zachowań konsumentów.

W ostatnim z prezentowanych wymiarów konsumpcja jest jedną z czterech faz reprodukcji społecznej, która obejmuje: produkcję, podział, wymianę i konsumpcję (Bywalec 2010, s. 60).

W niniejszej monografii konsumpcją będzie nazywany zarówno akt, jak i proces nabywania oraz użytkowania produktów lub usług w celu zaspokojenia potrzeb własnych bądź otoczenia w akcie spożycia. Takie ujęcie definicyjne pozawala szeroko zakreślić granice konsumpcji, a jednocześnie odróżnić ją od pojęć pokrewnych, np. zachowań konsumentów.

Konsumpcja, stanowiąc istotny element życia człowieka, a przede wszystkim jego zachowań rynkowych, pełni kilka podstawowych funkcji. Z tego względu należy mówić o społeczno-humanistycznym i gospodarczym znaczeniu konsumpcji. W wymiarze społeczno-humanistycznym konsumpcja służy podtrzymywaniu życia oraz stanu zdrowia człowieka, warunkuje jego samopoczucie i jakość życia, w tym służy poszerzaniu wiedzy i kwalifikacji. Konsumpcja pozwala na utrzymanie zdrowia i stanowi wartość w życiu człowieka. Umożliwia zaspokajanie nie tylko potrzeb fizjologicznych, lecz również potrzeb: bezpieczeństwa (np. posiadanie mieszkania), przynależności (np. za sprawą konsumpcji atrybutów identyfikujących grupy społeczne), uznania (np. dzięki konsumpcji atrybutów społecznie akceptowanych, uznawanych za prestiżowe), samorealizacji (np. poprzez tworzenie warunków do realizacji zawodowej). Konsumpcja jest także środkiem poznawania otoczenia, gromadzenia wiedzy o świecie, wpływa na rozwój intelektualny, pobudza ruchliwość przestrzenną (Bywalec, Rudnicki 1999, s. 64-67; Bywalec 2012; Bywalec 2016).

W gospodarczym znaczeniu, w wymiarze mikroekonomicznym konsumpcja oddziałuje na kształtowanie zamożności lub ubóstwa gospodarstwa domowego. W wymiarze makroekonomicznym - kształtuje poziom rozwoju gospodarczego danego społeczeństwa. Chęć osiągnięcia jej odpowiedniego poziomu mobilizuje do aktywności gospodarczej (Bywalec, Rudnicki 2002).

W wąskim rozumieniu zaś pojęcie konsumpcji sprowadza się do pojęcia spożycia. Na potrzeby statystyczne jest stosowany podział wydatków gospodarstw domowych - zgodnie z zaleceniami Europejskiego Systemu Rachunków Narodowych i Regionalnych w Unii Europejskiej (ESA 2010) - na spożycie i oszczędności. Część ekonomistów postuluje zamienne stosowanie pojęć: konsumpcja i spożycie (Bywalec 2007, s. 13). W praktyce jest ono odpowiednikiem wąskiego rozumienia pojęcia konsumpcji. 
W ujęciu statystycznym do spożycia zalicza się: wydatki poniesione przez ludność na zakup produktów (wyrobów i usług); usługi pośrednictwa finansowego; wartość oszustw na podatku od towarów i usług (tzw. VAT fraud); wartość spożycia naturalnego produktów rolnych pochodzących z własnej produkcji; opłaty za usługi związane z systemem ubezpieczeń społecznych; wartość usług mieszkaniowych stanowiącą czynsze umowne w odniesieniu do mieszkań użytkowanych przez właścicieli i najemców oraz czynsze najmu dla mieszkań w budynkach czynszowych. Wartość spożycia równa się przychodom ogółem w sektorze gospodarstw domowych, pomniejszonym o odrębnie oszacowaną kwotę oszczędności brutto (Mały Rocznik 2015, s. 143).

W związku z tym, ze względu na cele statystyczne istotne jest rozumienie pojęcia oszczędności brutto. Stanowią one część dochodów do dyspozycji brutto przeznaczonych na: akumulację brutto (nakłady brutto na środki trwałe, przyrost rzeczowych środków obrotowych oraz nabycie pomniejszone o rozdysponowanie aktywów o wyjątkowej wartości), transfery kapitałowe, wierzytelności netto lub zadłużenie netto i rezerwy w funduszach emerytalnych (Mały Rocznik 2015, s. 143).

Spożycie oznacza więc tę część dochodu gospodarstwa domowego, która jest przeznaczana na bieżące wydatki, czyli pozostaje w konkurencji wobec oszczędności. Jednocześnie należy zauważyć, że strumień oszczędności w gospodarce wiąże się ze zmianą konsumpcji bieżącej w konsumpcję przyszłą. Oszczędności bowiem przeradzają się w konsumpcję (rozumianą w ujęciu szerokim) w przyszłości, przykładowo przez zakup: nieruchomości, samochodu, usługi edukacyjnej. W szerokim rozumieniu konsumpcja nie jest więc równa spożyciu w ujęciu GUS, gdyż obejmuje jedynie tzw. konsumpcję bieżącą.

Z powyższych rozważań wynika, że konsumpcja nie jest pojęciem jednorodnym. W jej zakresie z racji wskazanego wyżej kryterium należy wyróżnić - stosunek czasowy między osiągnięciem dochodu a konsumpcją - konsumpcję bieżącą i przyszłą.

Pod względem kryterium podmiotowego można wyróżnić konsumpcję indywidualną i zbiorową. O konsumpcji indywidualnej mówi się, gdy produkt bądź usługę konsumuje tylko i wyłącznie jedna osoba, natomiast gdy produkt lub usługa są konsumowane przez pewną grupę osób, mówi się o konsumpcji zbiorowej. Kategorię tę można podzielić na: konsumpcję gospodarstwa domowego, grupową i ogólnospołeczną (Bywalec 2010, s. 25).

Podobny podział - lecz wymagający wyraźnego odróżnienia - wprowadza pojęcia konsumpcji prywatnej i publicznej. Opiera się on na kryterium źródła finansowania. Konsumpcja prywatna jest finansowana ze środków własnych konsumenta, gospodarstwa domowego bądź grupy społecznej. Zazwyczaj zaspokaja ona indywidualne potrzeby jednostek. Z kolei, kon- 
sumpcja publiczna jest finansowana ze środków publicznych, w tym głównie ze środków budżetowych (Janoś-Kresło 2006, s. 66). Konsumpcja publiczna nie jest jednak równoznaczna z konsumpcją zbiorową. Do jej zaistnienia nie jest bowiem wymagany zbiorowy charakter konsumowania (mimo że większość dóbr publicznych ma takowy), lecz finansowanie ze środków publicznych (Bywalec 2010, s. 26). Przykładem może być oświetlenie na terenie wspólnoty mieszkaniowej, mające charakter konsumpcji zbiorowej, finansowanej z prywatnych środków członków spółdzielni.

Kryterium kolejnego podziału konsumpcji jest jej przedmiot. Z tej racji można wyróżnić konsumpcję dóbr materialnych i usług (Janoś-Kresło 2006, s. 66). Produkty materialne są: namacalne, określone, policzalne oraz jednolite pod względem jakościowym. Usługi przede wszystkim odróżnia cecha: niematerialności, niespójności, niepodzielności i nieskładowalności. Niematerialność oznacza przewagę pracy ludzkiej nad materialnym świadectwem usługi. Niespójność wiąże się niskimi możliwościami standaryzacji w zakresie jakości oraz możliwości odchyleń jakości od wzorca. Co więcej, jakość usługi jest w większej mierze subiektywna. Niepodzielność wynika z braku możliwości oddzielenia osoby usługodawcy od usługobiorcy. Usługa nie może być świadczona z wyprzedzeniem przed zgłoszeniem zapotrzebowania na nią, magazynowana ani przechowywana.

Natomiast, według kryterium pochodzenia dóbr konsumpcję dzieli się na: konsumpcję naturalną, społeczną i rynkową. Konsumpcja naturalna (zwana również autokonsumpcją) polega na konsumpcji produktów lub usług wytworzonych we własnym gospodarstwie domowym. Przykładem może być produkcja przetworów z owoców zebranych we własnym sadzie. Do konsumpcji rynkowej dochodzi w wyniku nabywania dóbr będących przedmiotem obrotu gospodarczego. Natomiast konsumpcja społeczna jest realizowana z pominięciem zasad rynkowych. Egzemplifikację stanowi korzystanie z dróg publicznych (Bywalec, Rudnicki 2002, s. 37).

Powyższe rozważania prowadzą do wyodrębniania kilku podstawowych płaszczyzn badawczych związanych z konsumpcją. Są nimi:

- $\quad$ sfera potrzeb;

- $\quad$ sfera środków służących zaspokajaniu potrzeb;

- $\quad$ sfera zachowań konsumentów;

- $\quad$ sfera konsekwencji wynikających z zachowań konsumentów (Bywalec, Rudnicki 2002, s. 9-12).

Problematyka konsumpcji jest także przedmiotem badań ekonomii dobrobytu w zakresie:

- $\quad$ kategorii jakości życia;

- $\quad$ kategorii dobrobytu społecznego (Bywalec 2010, s. 38-42). 
W pierwszym $\mathrm{z}$ wymienionych obszarów - mianowicie $\mathrm{w}$ zakresie rozpoznawania i analizy potrzeb - zasadne jest korzystanie zarówno z wiedzy: ekonomicznej, psychologicznej, jak i socjologicznej. Nauką, przede wszystkim zajmującą się analizą środków zaspokajania potrzeb, jest towaroznawstwo i zarządzanie, w tym marketing. Nauki te badają kwestie związane z cechami produktu, dostosowywaniem ich do potrzeb odbiorców i jakością. Sfera zachowań konsumpcyjnych jest analizowana w równej mierze na gruncie: ekonomii, nauk o zarządzaniu, socjologii, jak i psychologii ekonomicznej. Konsekwencje zachowań konsumentów można rozpatrywać tak w skali mikro (czym zajmuje się: mikroekonomia, psychologia ekonomiczna), jak i w skali makro (co jest przedmiotem zainteresowania makroekonomii). Kwestie zachowań konsumentów są również analizowane na gruncie ekonomii behawioralnej, która różni się od klasycznych analiz decyzyjnych ekonomii tym, iż uwzględnia zmienne psychologiczne i społeczne, odrzucając jednocześnie założenie o pełnej racjonalności konsumentów. Szczególnym przedmiotem zainteresowania analiz są odstępstwa od racjonalnych zachowań, traktowane jako skutki ograniczeń poznawczych respondentów, których następstwem są systematyczne zniekształcenia w ocenie sytuacji decyzyjnej, w wyniku stosowania uproszczonych reguł wnioskowania, zwanych błędami poznawczymi (cognitive bias) (Matel, Poskrobko 2016). Można więc stwierdzić, że tematyka badań zachowań konsumentów należy do interdyscyplinarnych obszarów badań, których centrum zainteresowania stanowią zachowania gospodarcze, będące przedmiotem badań ekonomii, jednak celem ich wyjaśnienia słuszne jest sięganie do teorii innych nauk, w tym głównie nauk z zakresu: psychologii, socjologii i zarządzania, które pozwalają na budowę mikroekonomicznych podstaw oraz analizę makroekonomicznych konsekwencji zachowań jednostkowych.

W procesie konsumpcji istotna jest identyfikacja pojęć wyznaczających stronę podmiotową, do których należą: konsument, nabywca, użytkownik oraz gospodarstwo domowe.

$\mathrm{W}$ literaturze pojęcie konsumenta bywa różnie definiowane. W teorii ekonomii oznacza ono osobę dokonującą wyboru i tworzącą popyt a także osobę, która konsumuje dobro i/lub usługę. Według definicji T. Kramera, konsumentem jest: "osoba fizyczna nabywająca i spożywająca (użytkująca) dobra i usługi" (Kramer 2004, s. 71). Z punktu widzenia psychologii ekonomicznej konsument to podmiot rynkowy odczuwający potrzebę oraz dążący do jej zaspokojenia przez działania rynkowe.

Powstaje zatem pytanie, czy do bycia konsumentem jest konieczne osobiste nabywanie dóbr i ich użytkowanie, czy też wystarczającym warunkiem jest akt nabycia produktu, a może akt jego użytkowania? Odpowiadając na to 
pytanie, należy dokonać rozróżnień między takimi pojęciami, jak: konsument, nabywca i użytkownik.

Nabywcą jest osoba dokonująca aktu zakupu. Nie musi być użytkownikiem, np. kiedy nabywa produkt przeznaczony dla innej osoby. Nie musi więc uczestniczyć w procesie użytkowania (Janoś-Kresło 2006, s. 12-16). Z kolei, użytkownik to osoba, która korzysta z danego dobra. Nie oznacza to jednak, że bierze udział w procesie decyzyjnym dotyczącym jego nabycia.

Wobec powyższego, należy stwierdzić, że pojęcie konsumenta nie jest tożsame z pojęciem nabywcy. Konsument to osoba, która zarówno nabywa, jak i użytkuje dobra. Nie jest nim więc nabywca, który nie użytkuje dóbr i użytkownik, który dóbr nie nabył. Na zachowania konsumenta składa się zarówno nabywanie, posiadanie, jak i użytkowanie produktu (Szczepański 1981, s. 172). Zgodnie z definicją: "konsument jest to jednostka, która odczuwa i zaspokaja potrzeby konsumpcyjne, wykorzystując w tym celu dobra materialne oraz usługi zakupione na rynku (konsumpcja rynkowa), środki wytworzone we własnym gospodarstwie" (Łukasik 2008, s. 15). W takim rozumieniu pojęcie nabywania nie jest ograniczone do uczestniczenia w obrocie gospodarczym, lecz odnosi się do "wchodzenia w posiadanie" danego dobra.

Istota pojęcia konsumenta wydaje się zatem bliższa roli użytkownika niż nabywcy, czego jednak nie potwierdzają ustalenia prawne. Pojęcie konsumenta jest definiowane w art. 22 Ustawy z dnia 23 kwietnia 1964 roku - Kodeks cywilny, zgodnie z którym: „za konsumenta uważa się osobę fizyczną dokonującą z przedsiębiorcą czynności prawnej niezwiązanej bezpośrednio z jej działalnością gospodarczą lub zawodową". Takie przyjęcie definicji konsumenta skutkowałoby przeniesieniem akcentu znaczeniowego z pojęcia użytkownika na pojęcie nabywcy. Zakres niniejszego opracowania uniemożliwia taką postawę analityczną.

W prezentowanym opracowaniu przyjmuje się wąskie rozumienie pojęcia konsumenta, czyli osoby biorącej udział w procesie decyzyjnym: nabywającej, tj. wchodzącej w posiadanie dóbr i/lub usług w celu zaspokojenia potrzeb oraz je użytkującej. Warto zaznaczyć, iż definicję tę przyjęto nie ze względu na przekonanie o jej pełnej poprawności, ale ze względu na charakter prowadzonych rozważań, w tym potrzebę zachowania udziału analizowanych podmiotów w całym procesie decyzyjnym.

Pojęciem węższym znaczeniowo od pojęcia konsumenta (przez którego rozumie się pojedynczą jednostkę) jest gospodarstwo domowe, na to natomiast zazwyczaj (choć nie zawsze) składa się kilku konsumentów, użytkowników lub nabywców. Zgodnie z definicją: "gospodarstwo domowe jest jedno- lub wieloosobowym podmiotem gospodarczym, działającym w sferze 
konsumpcji, opartym najczęściej - choć niekoniecznie - na więzach rodzinnych, którego celem jest wszechstronne zaspokajanie potrzeb wszystkich jego członków, dzięki uzyskiwanym (...) dochodom" (Begg, Fischer, Dornbusch 2007, s. 42). Oznacza to, że każde gospodarstwo domowe składa się z konsumentów, zaś nie każdy konsument tworzy osobne gospodarstwo domowe. Wyeksponowanie pojęcia gospodarstwa domowego jako podmiotu konsumpcji jest konieczne głównie ze względów statystycznych. Badania z zakresu konsumpcji, prowadzone m.in. przez Główny Urząd Statystyczny oraz prezentowane w ramach Narodowych Spisów Powrzechnych, przedstawiają dane w odniesieniu do gospodarstw domowych.

Interpretacja pojęcia konsumpcji i konsumenta służy próbie operacjonalizacji zachowań konsumentów. E. Kieżel zaproponowała definicję, według której stanowią one: „spójną całość czynności, działań, postępowań związanych z dokonywaniem wyborów w procesie zaspokojenia potrzeb konsumpcyjnych w określonych warunkach społecznych, kulturowych i ekonomicznych" (Kieżel 2000, s. 58). Definicja ta kładzie nacisk na konsekwencje dotyczące zachowań konsumentów, jakie wynikają z przyjęcia ścisłego terminu konsumenta, przez który rozumie się podmiot racjonalnie gospodarujący. Cecha ta jest wiąże się ze spójnością jego zachowań.

J.F. Engel i inni sprecyzowali zachowania konsumentów jako: „ogół działań związanych z uzyskaniem i użytkowaniem produktów i usług oraz dysponowaniem nimi, wraz z decyzjami poprzedzającymi i warunkującymi te działania" (Engel, Blackwell, Miniard 1993, s. 4). Na uwagę zasługuje użycie słowa uzyskiwanie zamiast nabywanie. Autorzy, nie wskazując poszczególnych czynności składających się na zachowania konsumentów, szeroko zakreślili ich granice semantyczne. W opinii F. Hansena, zachowania konsumentów to: „ogół działań i percepcji konsumenta składających się na przygotowanie decyzji dotyczącej wyboru produktu, dokonanie owego wyboru oraz konsumowanie" (Hansen 1972, s. 15). W obu wskazanych definicjach nie uwzględnia się fazy oceny zachowania konsumenta i określenia jego poziomu satysfakcji, które warunkują kolejne procesy decyzyjne. Kwestia ta znalazła się w polu zainteresowań L. Schiffmana i L.L. Kanuka. Zgodnie z tą interpretacją, zachowania konsumenckie to proces podejmowania decyzji o zakupie na podstawie czynników poznawczych i emocjonalnych, takich jak: rodzina, przyjaciele, reklamodawcy, wzorce, nastroje i sytuacja, które wpływają na zakup, natomiast na ten składają się działania związane z: poszukiwaniem, zakupem, użytkowaniem i oceną dóbr i usług, mających zdolność zaspokojenia potrzeb (Schiffman, Kanuk 2010, s. 6). W takim ujęciu, w zakres zachowań konsumentów wchodzi również ocena zachowania konsumenta, tj. oszacowanie satysfakcji oraz wynikające z niej uczenie się. 
Jest ona istotnym elementem, gdyż pozwala na skrócenie procesów decyzyjnych dzięki doświadczeniom.

Co więcej, definicja zaproponowana przez L.G. Schiffmana i L.L. Kanuka zwraca uwagę na kolejny, istotny problem. Czy niezbędny jest udział danego produktu w procesie zaspokajania potrzeb, czy tylko istniejąca możliwość takiego zaspokojenia? Wydaje się, iż aby dane zachowanie zostało zaliczone do grona konsumenckich, nie jest konieczny rzeczywisty udział produktu W zaspokojeniu potrzeby, pomimo osobistego użytkowania. Ta kwestia wiąże się z elementem analizy konsumpcji, jakim jest jej ocena w skali mikro (satysfakcja lub dysonans pozakupowy). Nie ma więc potrzeby wyłączania z zachowań konsumpcyjnych tych aktów nabywania i użytkowania, które nie przyczyniły się do zaspokojenia potrzeby. Należy się zastanowić, czy - operacjonalizując pojęcie zachowań konsumentów, w ogóle istnieje wymóg odwoływania się do zaspokojenia potrzeby w sensie dokonanym. Zdaniem autorów, warunkiem wystarczającym jest potencjalna zdolność produktu do zaspokojenia danej potrzeby lub przekonanie konsumenta o takiej zdolności.

Zachowania rynkowe konsumentów mogą być analizowane według różnych kryteriów. Jednym z nich jest stopień uświadomienia potrzeby, pozwalający na wyróżnienie zachowań zamierzonych i niezamierzonych. Zachowania zamierzone obejmują wszystkie etapy procesu decyzyjnego. Są planowane, rozważane pod względem wariantów zaspokojenia potrzeby oraz wyboru odpowiedniego z nich. Decyzje nieplanowane cechują się skróceniem procesów decyzyjnych (Rudnicki 2012, s. 12). Są to decyzje impulsywne lub rutynowe.

Zgodnie z kolejnym kryterium, jakim jest dobrowolność zachowań, wyróżnia się zachowania przymusowe i dobrowolne. Pierwsze z wymienionych są związane z koniecznością przestrzegania przepisów prawnych lub pełnioną rolą społeczną (np.: ucznia, pacjenta). Podobnie, decyzje takie mogą występować w warunkach monopolu, kiedy konsument, chcąc zaspokoić daną potrzebę, nie ma możliwości wyboru ze względu na brak konkurencji wśród dostawców (Rudnicki 2012, s. 33).

Zachowania konsumentów na rynku przyjmują formę procesu decyzyjnego. Podejmowanie decyzji polega na dokonaniu wyboru z grona konkurujących ze sobą rozwiązań danej sytuacji problemowej (alternatyw), czego warunkiem jest istnienie znanego zbioru różnych możliwości zaspokojenia potrzeby. W procesie decyzyjnym wyodrębnia się stronę podmiotową i przedmiotową. Jak zauważył L. Rudnicki: „Przedmiotem decyzji są rzeczy, działania lub rozwiązania problemu" (Rudnicki 2004, s. 49). Przedmiotem decyzji konsumenckiej będą więc określone warianty zaspokojenia danej potrzeby. 
Z kolei: „podmiotem jest jednostka lub grupa osób, dokonująca wyboru i ponosząca odpowiedzialność za swą decyzję" (Rudnicki 2004, s. 49). W odniesieniu do decyzji konsumenckich podmiotem będzie konsument.

Proces podejmowania decyzji przez konsumentów jest złożony. Można wyróżnić kilka rodzajów decyzji, takich jak:

- decyzja dotycząca przeznaczenia środków na konsumpcję bieżącą lub przyszłą, spożycie lub oszczędności;

- decyzja związana z celem, podejmowana w wyniku uszeregowania potrzeb w kolejności pilności ich zaspokajania;

- decyzja obejmująca wybór konkretnego produktu lub usługi (wybór środka i wariantu zaspokojenia potrzeby) (Garbarski 1998, s. 86).

Głównie przed konsumentem pojawia się problem decyzji dotyczący formy konsumpcji, przez którą rozumie się konsumpcję bieżącą i przyszłą. Chodzi więc o decyzję, czy dokonać bieżącego zakupu, czy też odłożyć go w czasie. Bieżące potrzeby jednostki konkurują z potrzebami przyszłymi. Na tym etapie konsument odpowiada na pytania: „wydać czy zaoszczędzić oraz jaką część dochodu przeznaczyć na spożycie bieżące?" (Garbarski 1998, s. 22). Konsument w tym zakresie dokonuje podziału dochodu na spożycie i oszczędności (Rudnicki 2004, s. 49-51).

Następnie konsument podejmuje decyzję w odniesieniu do kolejności zaspokajania odczuwanych potrzeb. Dzieli dochód ogółem na zakup poszczególnych grup produktów i usług. Kryteria grupowania wynikają zarówno z: potrzeb fizjologicznych, pełnionych ról społecznych, jak i aspiracji. Na tym etapie konsument odpowiada na pytania: jak podzielić środki pieniężne na zakup poszczególnych grup produktów oraz jakie potrzeby zaspokoić w pierwszej kolejności.

Po dokonaniu decyzji wiążącej się rodzajem zaspokajanej potrzeby, konsument rozstrzyga o sposobie jej zaspokojenia. W tym obszarze rozpoznaje możliwe warianty, ocenia je na podstawie posiadanych informacji i przeszłych doświadczeń, wybiera miejsce zakupu, cechę produktu lub usługi, w tym marki. Po zakupieniu produktu, konsument podejmuje decyzję o sposobie i czasie jego użytkowania. Decyduje, w jakich okolicznościach z niego skorzystać (Rudnicki 2004, s. 49-51). Na tym etapie konsument postanawia więc w zakresie:

- $\quad$ wyboru konkretnych produktów - które marki produktu wybrać? jakie cechy powinien posiadać produkt?

- $\quad$ wzorca zakupu - gdzie dokonać zakupu? czy dokonać porównań między sklepami? jakich informacji szukać? w jakim momencie zakończyć poszukiwanie informacji? 
- $\quad$ sposobu użytkowania - kiedy wykorzystać produkt? kiedy zrezygnować z użytkowania produktu (oddać, sprzedaż, wyrzucić)? (Rudnicki 2012, S. 41).

W procesie podejmowania decyzji konsumenckiej można wyróżnić więc kilka podstawowych etapów. W literaturze najczęściej wyodrębnia się pięć faz tego procesu (rysunek 7).

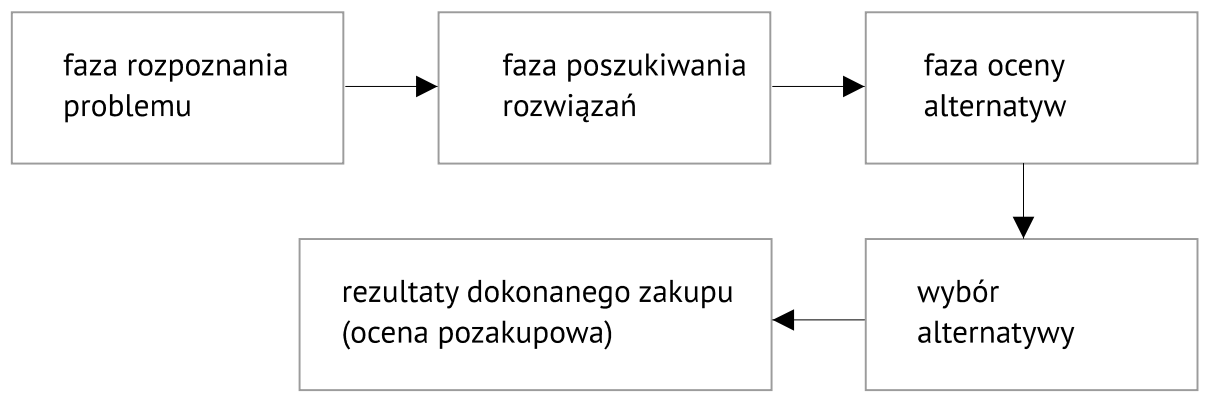

Rysunek 7. Fazy procesu decyzyjnego konsumenta

Źródło: opracowanie własne na podstawie: Jachnis, Terelak 1998, s. 104.

Pierwszą fazą w procesie decyzyjnym konsumenta jest rozpoznanie problemu, czyli uświadomienie potrzeb konsumpcyjnych. Polega ono na uruchomieniu motywu działania w efekcie odczucia potrzeby, wyrażanej odmiennością stanu pożądanego od stanu istniejącego. Jak zauważyli A. Jachnis i J.F. Terelak: "stan pożądany jest wywołany przez czynniki, które wpływają na aspiracje i sytuacje konsumenta (w tym: kultura, subkultura, grupa odniesienia, styl życia)" (Jachnis, Terelak 1998, s. 104). Odczuwanie potrzeby przez jednostkę wiąże się z uświadomieniem sobie, że istnieje różnica między stanem, do jakiego osoba zmierza, a stanem obecnym. W takiej sytuacji, w wyniku dążenia do przywrócenia równowagi, zostaje uruchomiony motyw działania.

W fazie poszukiwania rozwiązań konsument rozpoznaje możliwe drogi zaspokojenia odczuwanej potrzeby. W tym celu może prowadzić poszukiwania wewnętrzne i/lub zewnętrzne. W pierwszym przypadku chodzi o wyszukiwanie w pamięci możliwych rozwiązań. W drugim przypadku konsument poszukuje informacji: wśród znajomych, u sprzedawców, w przekazach reklamowych, w miejscu sprzedaży. Podstawowe warianty poszukiwania to:

- bazowanie na własnym doświadczeniu i wiedzy;

- bazowanie na doświadczeniu i wiedzy innych osób;

- bazowanie na informacji udostępnianej przez środki masowego przekazu;

- $\quad$ kombinacja powyższych źródeł informacji (Rudnicki 2012, s. 47). 
Konsument - który nie posiada pełnej wiedzy na temat problemu decyzyjnego oraz metod jego rozwiązywania - może wykazywać się różnym poziomem zaangażowania w poszukiwanie informacji o produktach. Konsument stara się przywołać z pamięci doświadczenia związane z poprzednimi zakupami, zdobywa informacje u innych, zwłaszcza w zakresie ich doświadczeń. Jest aktywny w przestrzeni sprzedażowej, porównując cechy produktów i biorąc pod uwagę opinię sprzedawców, szuka również informacji w innych źródłach, takich jak: poradniki, strony internetowe, fora internetowe. Intensywność poszukiwania informacji przede wszystkim jest związana z: siłą bodźca motywującego do zakupu, posiadanym doświadczeniem, łatwością w dostępie do informacji, a także cechami osobowościowymi konsumenta (Rudnicki 2012, s. 47-48). Aktywność ta wiąże się także z: cechami nabywanych dóbr, ich ceną, skomplikowaniem technologicznym, szerokością wyboru, innowacyjnością.

Najczęściej aktywność konsumenta w poszukiwaniu informacji prowadzi do podjęcia przemyślanej, świadomej, a w konsekwencji bardziej satysfakcjonującej decyzji. Z drugiej strony z tą aktywnością łączy się pewien dodatkowy koszt w postaci czasu poświęconego na poszukiwanie informacji. W takim rozumieniu różnica $\mathrm{w}$ poziomie satysfakcji płynącej z decyzji rekompensuje czas wolny, jaki konsument angażuje w gromadzenie informacji. Z tego względu podmioty podejmujące decyzje rynkowe najczęściej dostosowują czas przeznaczony na poszukiwanie informacji do poziomu ryzyka związanego z decyzją oraz wysokości kosztu alternatywnego, który jest wyższy w przypadku: znaczących, długofalowych, kosztownych i negatywnych konsekwencji podjętej decyzji.

Konsument, rozpoznając warianty wyboru dobra, tworzy zbiory rozwiązań. Sposoby zaspokojenia potrzeby, które konsument zna (przyjmuje za możliwe do zrealizowania), zaliczane są do tzw. zbioru znanego. Spośród nich konsument dokonuje decyzji w zakresie dostępnych sposobów realizacji potrzeby. Eliminuje pewną część rozwiązań na podstawie przyjętych kryteriów, takich jak: cena, dostępność zakupu, doświadczenie. W procesie decyzyjnym bierze więc pod uwagę jedynie część zbioru znanego, która tworzy "zbiór rozważany". W miarę gromadzenia informacji konsument wyodrębnia kolejne opcje wyboru, tworząc tzw. zbiór wyboru, dzięki któremu - w kolejnej fazie procesu - podejmie ostateczną decyzję (Rudnicki 2012, s. 48).

Wykluczenie kolejnych elementów zbioru jest wynikiem oceny poszczególnych wariantów zachowania. Konsument szacuje je pod względem kosztów, jakie musi ponieść, oraz korzyści, jakie może potencjalnie osiągnąć. Brane są również pod uwagę: cechy dostawcy, poziom ryzyka, możliwości finansowe. Liczba kryteriów jest zależna od rodzaju decyzji. Im istotniejsza 
dla konsumenta jest dana decyzja, tym więcej kryteriów bierze on pod uwagę w procesie porównań.

Między ostateczną decyzją a aktem zakupu może zaistnieć rozbieżność. Jej źródłem mogą być postawy innych osób, które mają wpływ na decyzję zakupową, w tym negatywne postawy wobec pewnych produktów oraz motywowanie do zmiany decyzji. Wpływ ten jest zależny od siły związku konsumenta z otoczeniem. Na zmianę decyzji mogą oddziaływac także czynniki sytuacyjne. Należą do nich: zmiana oczekiwań co do przyszłych dochodów, zmiany na rynku, zmiana w hierarchii potrzeb, np. choroba członka rodziny wymagająca poniesienia nakładów na leczenie (Rudnicki 2012, s. 54).

Ostatnim etapem procesu podejmowania decyzji przez konsumenta jest ocena podjętej decyzji konsumenckiej. Konsument stwierdza, czy poziom zaspokojenia jego potrzeb był zgodny z oczekiwanym. Doświadcza więc określonych stanów emocjonalnych związanych z satysfakcją pozakupową lub jej brakiem. Po dokonaniu zakupu konsument może odczuwać:

- $\quad$ stan satysfakcji;

- $\quad$ stan braku satysfakcji;

- $\quad$ stan dyssatysfakcji (Falkowski, Tyszka 2009).

Negatywna rozbieżność między oczekiwaniami a doświadczeniem skutkuje stanem dyssatysfakcji. Następstwem pozytywnej rozbieżności jest kształtowanie się stanu satysfakcji. Jeżeli konsument miał oczekiwania, które zostały spełnione, występuje nie tyle stan zadowolenia, ile stan obojętności, który można określić jako stan braku satysfakcji (Tyszka 2004, s. 454).

Zatem ocena pozakupowa nierozerewalnie wiąże się z oczekiwaniami konsumenta. Ich przyczyną mogą być: wcześniejsze doświadczenia konsumentów, informacje pochodzące od innych osób, komunikaty wysyłane przez producenta. W tym zakresie ekonomia neoklasyczna przyjęła, sformułowaną przez J.F. Mutha, teorię racjonalnych oczekiwań. Zakłada ona, że oczekiwania są zgodne z teoriami ekonomicznymi. Po pierwsze, wynika to z założenia, że informacje są rzadkie i nie są marnowane; po drugie, że oczekiwania są formułowane za pomocą obowiązującego modelu gospodarki. Ewentualne odchylenia racjonalności oczekiwań mogą mieć charakter błędów stochastycznych, które są błędami przypadkowanymi (Muth 1961, s. 315). Tym samym konsument zyskuje zdolność przewidywania. Teoria racjonalnych oczekiwań eliminuje niepewność i niewiedzę. W dalszej części rozważań aspekt ten zostanie jednak poddany dyskusji. 


\subsection{Proces akceptacji innowacji przez konsumentów}

Istotą efektywności innowacji jest jej weryfikacja rynkowa. P.P. Saviotti i A. Pyka wskazali, iż podstawą kreowania skutecznych innowacji jest akceptacja ze strony popytowej. Ich zdaniem, sam proces kreowania innowacji może nie mieć wpływu na wzrost gospodarczy, jeżeli innowacyjne produkty nie są nabywane przez konsumentów i cechuje je niska akceptacja ze strony odbiorców. Brak popytu na nowe produkty jest barierą związaną nie tylko z wdrażaniem innowacji, ale i destymulantą dla całego procesu innowacyjnego. Zniechęca bowiem przedsiębiorstwa do poszukiwania nowych rozwiązań (Saviotti, Pyka 2016, s. 5).

Fakt, iż między działalnością innowacyjną przedsiębiorstw a zachowaniami rynkowymi konsumentów zachodzą istotne relacje nie pozostawia wątpliwości. Relacje te badane są jednak na różnych płaszczyznach. K. Włodarczyk do najważniejszych obszarów badań współczesnych zachowań rynkowych konsumentów w kontekście wprowadzania na rynek innowacji zaliczył:

- innowacyjne wzory konsumpcji,

- dyfuzję innowacji,

- $\quad$ wpływ norm, wartości, przekonań i uwarunkowań charakterologicznych na przyjmowanie innowacji,

- nowe technologie,

- zachowania konsumentów innowatorów,

- modele przyjmowania innowacji przez konsumentów,

- opór przeciwko innowacjom ze strony grup konsumentów (Włodarczyk 2015, s. 240-241).

W obszarze badań nad innowacyjnymi wzorcami konsumpcji analizie są poddawane sposoby korzystania $z$ innowacyjnych produktów i usług oraz poziom wiedzy z danego zakresu posiadanej przez konsumenta. W wymiarze dyfuzji innowacji obszarem badań jest najczęściej wpływ: struktur społecznych, wzorców rodzinnych, wiedzy i mody na rozprzestrzenianie się innowacji. W zakresie analizy: norm, wartości, przekonań i osobowości innowacyjność konsumenta jest traktowana jako specyficzna cecha charakteru, polegająca na skłonności do kupowania nowości na rynku wcześniej niż inni konsumenci. W tym ujęciu są rozpatrywane etyczne podstawy innowacji, w tym przesłanki proekologiczne. W wymiarze nowych technologii przedmiotem badań są wzorce nabywania (w tym wykorzystanie Internetu oraz nowoczesnych osiągnięć technologii do dokonywania zakupów), a także konsumpcja mass mediów przez Internet. W tym wymiarze obszarem badań, który nieustannie rozwija się, jest również między konsumentem a produ- 
centem, która w dużej mierze jest możliwa dzięki wykorzystaniu nowoczesnych technologii. W wymiarze konsumentów-innowatorów jako szczególny przedmiot zainteresowań są traktowane prawidłowości zachowań tej grupy konsumentów, która nabywa innowacje jako pierwsza. Analizom są poddawane uwarunkowania ich decyzji, cechy charakteru oraz sposób postrzegania ryzyka. W wymiarze modelu przyjmowania innowacji przez konsumentów uwzględnia się czynniki zewnętrzne i wewnętrzne, sprzyjające nabywaniu innowacji, a także powodujące wobec nich opór. W przypadku oporu przeciwko innowacjom są badane bariery innowacyjności konsumentów, w tym głównie bariery: kulturowe, społeczne i psychologiczne, jak również formy odrzucenia innowacji (Włodarczyk 2015, s. 240-241).

W procesie kreowania innowacji ważne miejsce zajmuje badanie preferencji i oczekiwań konsumentów. Powstaje zatem pytanie, które za K. Mazurek-Łopacińską można sformułować następująco: „jak można poznać, ale także jak antycypować te oczekiwania, aby z sukcesem kreować innowacje zarówno produktowe, jak i marketingowe?" (Mazurek-Łopacińska 2015, s. 27).

Zależność między efektywnością innowacji a zachowaniami konsumentów wyznaczają zarazem spektakularne sukcesy, jak i porażki rynkowe. Tym samym np. do dóbr innowacyjnych, które odniosły sukces rynkowy dzięki przyjęciu ze strony konsumentów, można zaliczyć: telewizję kablową, miejskie wypożyczalnie rowerów, konsole Play Station. Z kolei, do porażek rynkowych innowacji, spowodowanych brakiem akceptacji ze strony konsumentów, można zaliczyć palmtopy, płyty typu DIVX ${ }^{2}$, Squirt Ketchup firmy Heinz $^{3}$ czy Crystal Pepsi ${ }^{4}$.

Zdaniem P.P. Saviotti i A. Pyka, aby pojawił się popyt na innowacyjne produkty, łącznie muszą zostać spełnione dwa warunki. Po pierwsze, konsumenci muszą posiadać dochody na poziomie umożliwiającym im ich nabywanie. Po drugie, konsumenci muszą przejawiać preferencje w zakresie nabywania innowacyjnych produktów i pozytywne postawy wobec nich (Saviotti, Pyka 2016, s. 5).

Preferencje konsumentów wobec innowacji rynkowych w literaturze są nazywane innowacyjnością konsumenta. A. Dąbrowska i inni zdefiniowali to pojęcie jako: „skłonność do kupowania nowych dóbr konsumpcyjnych wkrótce po ich pojawieniu się na rynku i wcześniej niż inni konsumenci" (Dąbrowska i in. 2015, s. 118). Taki sposób rozumienia przyjęto w niniejszej publika-

\footnotetext{
${ }^{2}$ Płyty do nagrywania filmów, które pozwalały tylko na jednokrotne odtworzenie, dzięki czemu nie był wymagany ich zwrot do wypożyczalni.

${ }^{3}$ Keczup w wielu kolorach (celem produkcji było oddziaływanie na młodsze grupy odbiorców, w tym głównie dzieci).

${ }^{4}$ Jest to napój Pepsi w bezbarwnej wersji.
} 
cji. Innowacyjność konsumentów opisuje więc ich stosunek do innowacji rynkowych (Zalega 2015, s. 15). Pojęcie innowacyjności konsumentów przez część autorów jest określane jako innowacyjność konsumencka. W wymiarze merytorycznym pojęcia te można uznać za tożsame. Rogers i Shoemaker sprecyzowali bowiem innowacyjność konsumencką jako stopień, w którym osoba relatywnie wcześniej akceptuje nowe idee i pomysły niż średnia członków danego systemu społecznego (Rogers, Shoemaker 1971, za: Badowska 2016, s. 68). Przez kategorię innowacyjności konsumenta rozumie się również cechę osobowości konsumentów przejmujących innowacyjne zachowania. Innowacyjność skłania konsumentów do wcześniejszego niż przeciętnie akceptowania nowych produktów (Gutkowska 2011, s. 108).

Obok innowacyjności konsumenta w literaturze jest również obecne pojęcie innowacyjnych zachowań konsumentów. A. Dąbrowska i inni wskazali, że przez to pojęcie należy rozumieć: „takie działania, które wykorzystują nowe możliwości dokonywania zakupów za pomocą komputera lub urządzeń mobilnych w sklepach internetowych" (Dąbrowska i in. 2015, s. 134). Na potrzeby prezentowanych rozważań pojęcie to będzie traktowane jednak szerzej, jako kategoria obejmująca działania konsumentów związane z nabywaniem innowacyjnych produktów oraz innowacyjne metody nabywania dóbr i usług opartych na technologiach informacyjnych.

Obok powyższego, w literaturze, zwłaszcza na gruncie badań marketingowych, jest analizowana innowacyjność naturalna lub wrodzona oraz - znajdująca się na niższym poziomie - innowacyjność realizowana. Jest ona określana jako tendencja do kupowania konkretnych, nowych produktów po pojawieniu się ich na rynku relatywnie szybciej od pozostałych konsumentów. Ogółem więc pojęcie innowacyjności konsumentów wiąże się z poziomem ich wiedzy o innowacjach i skłonnością do ich nabywania (Badowska 2016, s. 68).

Trudności z akceptacją innowacyjnych produktów przez odbiorców są związane $\mathrm{z}$ faktem postrzegania ryzyka zakupowego $\mathrm{w}$ nabywaniu nowych produktów. Decyzja o nabyciu innowacyjnego produktu należy bowiem do szczególnej kategorii decyzji podejmowanych w warunkach ryzyka, bazującej na założeniach teorii oczekiwanej użyteczności. W klasycznym podziale decyzji wyodrębnia się pod tym względem trzy warunki podejmowania decyzji, jakimi są: pewność, niepewność, ryzyko. Badania (prowadzone między innymi przez D. Ellsberga) dowiodły konieczności wyróżnienia czwartej kategorii, jaką jest niejasność. Jest to kategoria pośrednia między niepewnością a ryzykiem, wynikająca z nieznajomości prawdopodobieństwa wystąpienia określonych konsekwencji zdarzeń (osiągnięcia określonego poziomu satysfakcji pozakupowej) (Ellsberg 1961, s. 643-669). W odniesieniu do decyzji 
konsumentów ma ona miejsce, gdy jednostka nie potrafi oszacować szans na spełnienie oczekiwań dzięki nabyciu określonego produktu. Ryzyko bowiem odnosi się do tych sytuacji, w których, pomimo niezdefiniowania rezultatów, konsument potrafi ocenić (choćby subiektywnie) prawdopodobieństwo uzyskania określonego wyniku i przypisać go do poszczególnych alternatyw decyzyjnych. Z kolei, niepewność dotyczy sytuacji znajomości potencjalnych korzyści, przy braku możliwości oszacowania ich prawdopodobieństwa. Decyzje podejmowane w warunkach niejasności cechują się zarówno brakiem możliwości oceny potencjalnych konsekwencji, jak i prawdopodobieństwa ich osiągnięcia.

Konsumenci, szacując możliwy do osiągnięcia efekt, najczęściej odwołują się do wcześniejszych doświadczeń i opinii innych osób. Bazując na doświadczeniach z danym produktem, marką czy producentem, szacują szanse wystąpienia wyników pożądanych lub ryzyko poniesienia straty. Podejmują więc decyzje w warunkach ryzyka, czyli znanej niepewności. Z tego względu zakupy powtarzalne z czasem zaczynają być postrzegane jako podejmowane w warunkach pewności. Nie ma to jednak zastosowania do produktów innowacyjnych. Sytuacja decyzyjna jest zbliżona do tej w warunkach niejasności. To powoduje, że część konsumentów powstrzymuje się od decyzji zakupowych, oczekuje na informację, która pozwoli ocenić ewentualne skutki decyzji, ograniczyć niejasność jej podjęcia. Jak zauważyli A. Domurat i T. Zieliński: „Na przykład, widząc na etykiecie listę dodatków do żywności określonych skomplikowanymi nazwami chemicznymi lub symbolami «E-ileś», konsument, nie wiedząc, które z nich są obojętne dla zdrowia, a które nie, może z założenia odrzucać wszystkie produkty z takimi oznaczeniami" (Domurat, Zieliński 2013, s. 21-33).

A. Domurat i T. Zieliński celem zobrazowania sytuacji przedstawili dwa przykłady. Pierwszym z nich było wprowadzenie na rynek samochodów z napędem hybrydowym, a następnie samochodów z silnikiem benzynowym, poddanym tak zwanemu downsizingowi (dających możliwość uzyskania wyższej mocy przy niższej pojemności). Konsumenci nie posiadali odpowiedniej wiedzy na temat ich użytkowania, co zniechęcało ich do zakupu. Drugim przykładem była nieufność konsumentów do produktów elektronicznych (Domurat, Zieliński 2013, s. 21-33). Podsumowując, decyzja o nabyciu innowacyjnego produktu jest podejmowana w warunkach niejasności, co nie sprzyja akceptacji produktów przez odbiorców.

W literaturze przedmiotu klasyfikuje się konsumentów ze względu na poziom ich zachowań innowacyjnych. E.M. Rogers wymienił następujące kategorie: innowatorzy, osoby przyjmujące innowacje wcześnie, większość przyjmująca innowacje wcześnie, większość przyjmująca innowacje późno, 
opieszalcy (Rogers 2003). E. Martinez i inni wyróżnili pięć grup konsumentów, przyjmując przy tym nieco inną nomenklaturę (wcześni innowatorzy, pierwsi adapterzy innowacji, wczesna większość, późna większość, maruderzy) (Martinez i in. 1998, s. 323). Natomiast K. Mazurek-Łopacińska wymieniła cztery kategorie konsumentów:

- $\quad$ konsumenci-innowatorzy;

- $\quad$ nabywcy wcześni;

- $\quad$ wczesna większość;

- $\quad$ maruderzy (Mazurek-Łopacińska 2003, s. 37-43).

Na klasyfikacji K. Mazurek-Łopacińskiej będzie oparta dalsza analiza. W istocie wybór między wskazanymi klasyfikacjami nie ma tu istotnego znaczenia. Po pierwsze, różnice w ich zakresie głównie sprowadzają się do stosowanego nazewnictwa, są więc pozorne. Po drugie, szczególnym przedmiotem zainteresowania autorek monografii jest grupa konsumentów-innowatorów, wyróżniana we wszystkich klasyfikacjach, a pod pewnym wzgledem również grupa konsumentów nabywających innowacje wcześnie.

Konsumenci-innowatorzy to osoby, które są skłonne do podejmowania ryzyka, przejawiają zainteresowania nowymi technologiami, lubią wygodę, co jest częstą przyczyną poszukiwania nowych rozwiązań. Tymczasem najczęściej wysoki poziom innowacyjności towarzyszy ludziom młodym (Mazurek-Łopacińska 2003, s. 37-43). Analizując proponowaną klasyfikację - bazując na przyjętych rozważaniach w zakresie ryzyka i niepewności - warto zauważyć, że konsumentów-innowatorów od pozostałych grup odbiorców różni nie tyle niższa awersja do ryzyka, ile niższa awersja do niejasności. Decyzja o zakupie innowacyjnego produktu jest bowiem związana z tą kategorią warunków decyzyjnych, w których barierą zakupu staje się trudność oszacowania oczekiwanych korzyści oraz szans na ich osiągnięcie.

Na stworzenie aktualnej charakterystyki polskich konsumentów-innowatorów pozwalają wyniki badań realizowanych w 2015 roku przez zespół badawczy pod kierownictwem A. Dąbrowskiej. Na ich podstawie wskazano, że polscy konsumenci-innowatorzy należą do 2,5-procentowego segmentu populacji, przyjmującego nowe produkty jako pierwsi. Tę grupę konsumentów cechuje: wrażliwość na nowości rynkowe; zdolność do samodzielnego myślenia; aktywność w zapoznawaniu się z ofertą rynkową, w tym w zakresie nowych rozwiązań technicznych; podatność na zmianę trendów mody, w tym przekazywanych za pośrednictwem środków masowego przekazu (Dąbrowska i in. 2015, s. 121). Zazwyczaj konsumentów-innowatorów znamionuje: zadowalająca sytuacja materialna, ciekawość, chęć podkreślenia statusu poprzez zachowania nabywcze (tzw. konsumpcja statusowa), aktywność w życiu towarzyskim (Smoleń 2012, s. 97). 
Ze względu na fakt, iż - zgodnie z przytoczonymi wynikami badań - w Polsce grupa konsumentów-innowatorów stanowi niewielki odsetek populacji, tym samym znaczenie zyskuje możliwość stymulowania popytu na innowacje w innych grupach odbiorców. Kolejną grupą konsumentów, skłonną do akceptacji innowacji, są tzw. nabywcy wcześni. Sięgają oni po innowacje we wczesnych fazach jej wdrażania na rynek, jednak nie jako pierwsi. K. Mazurek-Łopacińska skonstatowała, że w tej grupie konsumentów istotne znaczenie ma symboliczna wartość produktów. Konsumenci dążą bowiem do uzyskania prestiżu za pomocą nabytych innowacji. Kierują się w większej mierze wpływem społecznym. Ponadto dążą do ograniczenia odczuwanego poziomu niepewności dzięki wzorowaniu się na innych (Mazurek-Łopacińska 2003, s. 37-43).

Kolejną grupą nabywców jest tzw. wczesna większość, wstrzymująca się od nabywania nowych produktów przed ich weryfikacją rynkową. To grupa, która w podejmowaniu decyzji rynkowych przywiązuje wagę do szerszego otoczenia społecznego, w tym do doświadczenia i opinii innych konsumentów. Osoby te cenią poczucie bezpieczeństwa w procesie zakupu, nie są skłonne do podejmowania nieprzemyślanych, ryzykownych zachowań, zwłaszcza kiedy nie posiadają odpowiedniej wiedzy na temat nabywanych produktów.

Najniższą innowacyjnością charakteryzują się konsumenci-maruderzy. Są sceptyczni wobec nowych rozwiązań wprowadzanych na rynek. Mają silne przyzwyczajenia i zazwyczaj cechują się lojalnością w stosunku do marek produktów. W grupie tej największy jest udział osób starszych (Mazurek-Łopacińska 2003, s. 37-43).

W związku z tym pojawia się pytanie, z jakich powodów konsumenci akceptują bądź odrzucają innowacje. Celem wyjaśnienia tego zagadnienia K. Mazurek-Łopacińska opisała proces przyjmowania innowacji przez konsumentów (rysunek 8.). W jego zakresie wyróżniła trzy fazy, tj.: poznawczą, afektywną i behawioralną (Mazurek-Łopacińska 2003, s. 69-71).

W fazie poznawczej konsumenci uświadamiają sobie istnienie nowości rynkowej. Następnie zapoznają się z: ofertą produktu, jego cechami, sposobami użytkowania. Określają oczekiwany poziom zaspokojenia potrzeb, jaki spowoduje nabycie danego produktu. Na tej podstawie dokonują kategoryzacji produktu pod względem użyteczności. W procesie kategoryzacji konsument klasyfikuje dany produkt do grupy znanych mu już dóbr rynkowych lub tworzy nową kategorię. Długość trwania fazy poznawczej zależy od innowacyjności konsumenta, a co za tym idzie, od takich cech, jak: skłonność do ryzyka, wiek czy styl konsumpcji. Faza ta jest najkrótsza wśród konsumentów-innowatorów, natomiast trwa nieco dłużej wśród wczesnych naśla- 
dowców. Kolejne grupy konsumentów (wyróżnione ze względu na innowacyjność) potrzebują więcej czasu oraz informacji na temat innowacji, aby podjąć decyzję o jej zakupie. To zaś jest podstawą kolejnej fazy przyjęcia innowacji, czyli fazy afektywnej (Mazurek-Łopacińska 2003, s. 69-71).

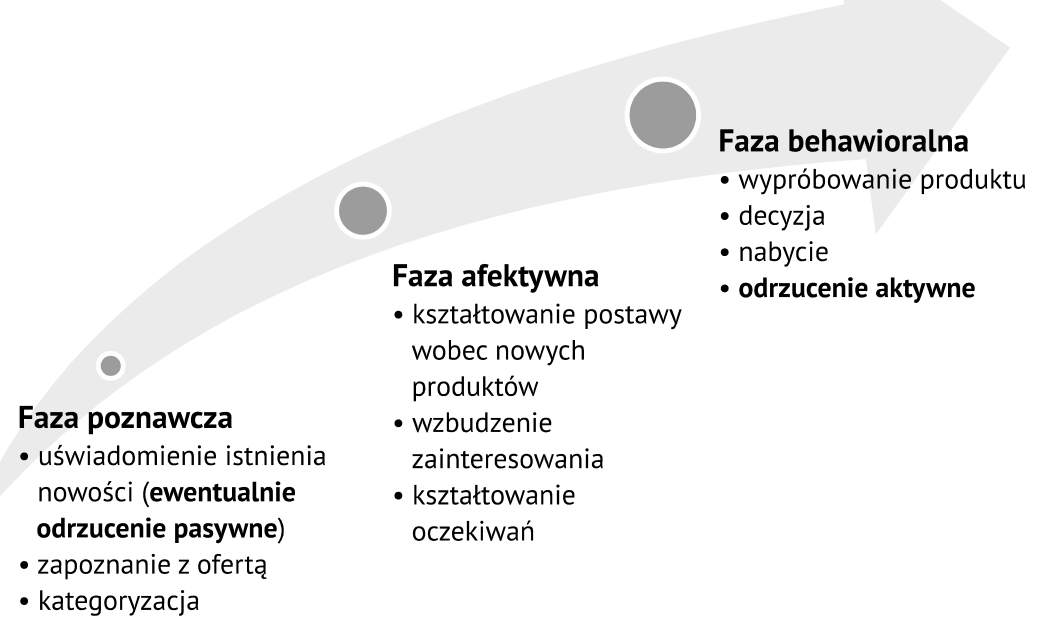

Rysunek 8. Proces przyjmowania innowacji przez konsumentów

Źródło: opracowanie własne na podstawie: Mazurek-Łopacińska 2003, s. 69-71; Rogers 2003.

W fazie afektywnej kształtuje się określona postawa konsumenta w stosunku do nowego produktu. Znaczenia nabierają: emocje, wzbudzanie zainteresowania, a w ich efekcie kształtowanie preferencji wobec danej nowości. Produkt jest oceniany przez pryzmat subiektywnych kryteriów formujących oczekiwania w odniesieniu do poziomu zaspokojenia potrzeb. Innowatorzy, od początku procesu przejawiający pozytywne nastawienie wobec nowości, są nią zainteresowani. Faza afektywna ma więc kluczowe znaczenie dla konsumentów o niższej innowacyjności, takich jak późna większość i maruderzy (Mazurek-Łopacińska 2003, s. 69-71).

W wyniku pozytywnego przebiegu fazy poznawczej i afektywnej, konsument przechodzi do behawioralnej fazy przyjęcia innowacji. W fazie tej konsumenci mogą dążyć do wypróbowania nowych produktów, w celu minimalizowania odczuwanego poziomu niepewności. Ostatecznie podejmują decyzję o nabyciu bądź odrzuceniu innowacyjnego produktu (Mazurek-Łopacińska 2003, s. 69-71). 
E.M. Rogers, tworząc model przyjmowania innowacji przez konsumentów, zwrócił uwagę na kwestię aktywnego i pasywnego odrzucenia innowacji w procesie podejmowania decyzji przez konsumentów. W modelu proponowanym przez K. Mazurek-Łopacińską odrzucenie następuje w fazie behawioralnej. W istocie do odrzucenia innowacji może jednak dojść znacznie wcześniej, czyli już w fazie poznawczej. Podstawą jest wyróżnienie dwóch form odrzucenia innowacji, a mianowicie:

- odrzucenie aktywne,

- $\quad$ odrzucenie pasywne (Rogers 2003).

Odrzucenie aktywne zachodzi wówczas, kiedy konsument rozważa zakup produktu, lecz podejmuje decyzję o jego zaniechaniu. Odrzucenie pasywne oznacza, że konsument nie rozważa nabycia danego produktu (Rogers 2003). Druga kategoria dotyczy głównie konsumentów-maruderów o silnym przywiązaniu do tradycji i nawyków oraz wysokiej lojalności wobec marek i konkretnych produktów, konserwatystów, przede wszystkim osób starszych. Tym samym model przyjmowania innowacji powinien uwzględniać te dwie kategorie odrzucenia, które zobrazowano na rysunku 8.

Zaprezentowany model odnosi się do indywidualnego procesu decyzyjnego. Proces rozprzestrzeniania się innowacji wśród konsumentów w praktyce nie odbywa się w izolacji od zjawisk i zachowań społecznych. Znaczącym kryterium rozprzestrzeniania się innowacji jest wpływ przebiegu indywidualnej akceptacji innowacji (przede wszystkim przez konsumentówinnowatorów) na pozostałe grupy nabywców. Akceptacja ta wywołuje bowiem swego rodzaju dodatkowe efekty w postaci naśladownictwa i wpływu informacyjnego. Konsumenci sięgający po innowacje "przygotowują" rynek do ich wchłonięcia. Manifestują ich użytkowanie, co oddziałuje na zachowania konsumentów-naśladowców. Tym sposobem popularyzują daną innowację, kreując dodatkowy popyt (Zalega 2015, s. 15).

Wpływ konsumentów-innowatorów na rozprzestrzenianie się innowacji może przybierać formę oddziaływania normatywnego i informacyjnego. W pierwszym przypadku konsumenci nabywający innowację jako pierwsi przekazują wzorzec do naśladowania. W drugim przypadku są źródłem informacji (porad, opinii) kształtujących decyzje pozostałych grup nabywców (Burgiel 2014, s. 47). Tym samym ich opinie są kluczowym elementem, który pozwala na eliminację poczucia niejasności decyzyjnej.

Innowacyjne zachowania konsumentów pełnią funkcje, które można rozpatrywać w wymiarze mikroekonomicznym (indywidualnym, społecznym, organizacyjnym) oraz w wymiarze makroekonomicznym (tabela 4.). 
Tabela 4. Funkcje innowacyjności konsumentów

\begin{tabular}{|c|c|c|c|}
\hline \multicolumn{4}{|c|}{ Funkcje innowacyjności konsumentów } \\
\hline \multirow[b]{2}{*}{ Makroekonomiczne } & \multicolumn{3}{|c|}{ Mikroekonomiczne } \\
\hline & $\begin{array}{c}\text { w wymiarze } \\
\text { indywidualnym }\end{array}$ & $\begin{array}{l}\text { w wymiarze } \\
\text { społecznym }\end{array}$ & $\begin{array}{c}\text { w wymiarze } \\
\text { organizacyjnym }\end{array}$ \\
\hline $\begin{array}{l}\text { - stymulowanie roz- } \\
\text { woju gospodarczego } \\
\text { przez innowacje } \\
\text { - stymulowanie roz- } \\
\text { woju gospodarki opar- } \\
\text { tej na wiedzy }\end{array}$ & $\begin{array}{l}\text { - wyższy poziom } \\
\text { satysfakcji } \\
\text { z zaspokojenia } \\
\text { potrzeb } \\
\text { - maksymalizacja } \\
\text { użyteczności }\end{array}$ & $\begin{array}{l}\text { - wptyw informacyjny } \\
\text { (szerzenie pozytyw- } \\
\text { nych lub negatyw- } \\
\text { nych opinii o ce- } \\
\text { chach innowacji) } \\
\text { - dostarczanie wzorca } \\
\text { zachowań }\end{array}$ & $\begin{array}{l}\text { - lepsze dostosowanie } \\
\text { strategii wdrażania no- } \\
\text { wych produktów } \\
\text { - maksymalizacja zysków } \\
\text { w pierwszych fazach } \\
\text { cyklu życia produktu } \\
\text { - motywacja do działal- } \\
\text { ności innowacyjnej }\end{array}$ \\
\hline
\end{tabular}

Źródło: opracowanie własne.

Z punktu widzenia gospodarki jako całości innowacyjność konsumentów służy tworzeniu odpowiednich warunków do innowacyjnych działań przedsiębiorstw, a co za tym idzie, stymuluje rozwój gospodarczy kraju oparty na innowacjach. Współcześnie nie ma już bowiem wątpliwości, iż innowacje są stymulantą wzrostu gospodarczego. Co więcej, działalność innowacyjna jest czynnikiem sprzyjającym rozwojowi koncepcji gospodarki opartej na wiedzy, której istotę stanowi traktowanie wiedzy (w tym dotyczącej prawidłowości zachowań odbiorców) jako zasobu organizacji.

W wymiarze indywidualnym szybka absorpcja innowacji przez konsumentów jest dla nich szansą na wyższy poziom zaspokojenia potrzeb. Pod uwagę są brane zarówno potrzeby niższego, jak i wyższego rzędu, w tym potrzeba: akceptacji społecznej, uzyskania prestiżu czy samorealizacji. W związku z tym, konsument nabywający innowacyjne produkty, dąży do maksymalizacji użyteczności, jednocześnie ponosząc pewien koszt jakim jest ryzyko zakupu nowych produktów.

W wymiarze społecznym innowacyjność konsumentów wpływa na rozprzestrzenianie się wzorów innowacyjnych zachowań w społeczeństwie. Konsumenci nabywający nowe produkty przekazują wiedzę w postaci opinii i porad, zarazem wyznaczają wzory konsumpcji do naśladowania.

Z perspektywy przedsiębiorstwa rozumienie uwarunkowań innowacyjnych zachowań konsumentów jest istotne ze względu na kształtowanie strategii wprowadzania nowych produktów na rynek. Pozwala bowiem na dostosowanie strategii konkurencyjnych i działań marketingowych do potrzeb odbiorców. Przyjęcie innowacji przez konsumentów skutkuje maksymalizacją 
nadwyżki ekonomicznej w pierwszych fazach cyklu życia produktu, co z kolei jest czynnikiem motywującym do dalszej działalności innowacyjnej.

W efekcie innowacyjność konsumentów pozytywnie oddziałuje na aktywność innowacyjną przedsiębiorstw i rozwój gospodarki. Należy stwierdzić, że wpływ innowacyjnych zachowań konsumentów w ujęciu mikro- i makroekonomicznym jest wzajemnie sprzężony.

\subsection{Akceptacja innowacji w aspekcie determinant zachowań konsumentów}

Z ustaleń poczynionych w poprzedniej części rozdziału można wyprowadzić pewne wnioski. Po pierwsze, efektywność wdrażania innowacji jest zależna od jej akceptacji przez rynek. Po drugie, na rynku można wyróżnić grupę tzw. konsumentów-innowatorów, którzy cechują się najwyższą skłonnością do nabywania innowacji. Po trzecie, w Polsce innowatorzy stanowią niewielką część społeczeństwa i są to głównie ludzie młodzi, aktywnie poszukujący informacji, podążający za trendami mody. Po czwarte, grupy innowatorów oddziałują informacyjnie i normatywnie, rozpowszechniając innowacje wśród konsumentów.

Wobec powyższego powstaje pytanie, co decyduje o skłonności konsumentów do akceptowania innowacji i nabywania innowacyjnych produktów. Jakie są determinanty innowacyjnych zachowań konsumentów? Odpowiedź na to pytanie nie jest prosta. Jak bowiem wskazali A. Reinstaller i B. Sanditov, dyfuzja innowacji wśród konsumentów nie obejmuje tylko rozpowszechniania informacji na temat nowości, lecz jest związana z szeroko rozumianą społeczną perswazją i zależy od stopnia niejednorodności konsumentów w gospodarce (Reinstaller, Sanditov 2005, s. 506).

Odpowiednią matrycą analizy uwarunkowań akceptacji innowacji przez konsumentów wydaje się klasyfikacja determinant ich zachowań rynkowych. Literatura dostarcza szeregu propozycji takich klasyfikacji. W niniejszej publikacji przyjęto podział na uwarunkowania: psychologiczne, demograficzne, społeczne, kulturowe (często ujmowane łącznie jako determinanty społeczno-kulturowe), ekonomiczne i marketingowe. Przyjęcie takiego rozróżnienia wynika z dążenia do wyeksponowania czynników wpływających na innowacyjne zachowania konsumentów, w tym demograficznych i kulturowych, często marginalizowanych w klasyfikacjach determinant zachowań nabywców. Przyjęty podział służy klarowności prowadzonego wywodu.

Pierwszą analizowaną grupą uwarunkowań są determinanty psychologiczne. G. Światowy zauważył, iż „obejmują one całokształt właściwości 
i procesów myślowych, uczuciowych i duchowych człowieka" (Światowy 2006, s. 57). Współcześnie zachowania konsumentów często są przedmiotem analiz interdyscyplinarnych. Można w tym zakresie odnaleźć płaszczyznę interdyscyplinarną między psychologią a ekonomią, gdyż w kontekście zachowań konsumentów istotą zainteresowania obu nauk stają się potrzeby. Psychologia zajmuje się rozwojem i strukturą potrzeb, zaś ekonomia bada sposób ich zaspokojenia w kontekście funkcjonowania rynku (Jachnis, Terelak 1998, s. 15-17).

Do psychologicznych determinant innowacyjnych zachowań konsumentów można zaliczyć: potrzeby, postawy i cechy osobowości konsumentów.

Zachowania konsumentów przede wszystkim są warunkowane istnieniem potrzeb będących stanem psychicznym człowieka, przejawiającym się brakiem czegoś, zauważeniem różnicy między stanem istniejącym a stanem oczekiwanym (Bombol 2006, s. 41-42). Wiedza na temat potrzeb konsumentów pozwala nie tylko lepiej rozpoznawać motywy ich działania, lecz również nimi kierować. Zgodnie z koncepcją A. Maslowa, można wyróżnić pięć podstawowych grup potrzeb, a mianowicie: potrzeby fizjologiczne (jak: jedzenie, sen, odpoczynek), potrzebę bezpieczeństwa (w tym: opieki, ładu, zależności), potrzebę przynależności (w tym: miłości, afiliacji), potrzebę szacunku (w tym: uznania, respektu, sławy, prestiżu, wolności), potrzebę samorealizacji (w tym: rozwoju, osiągania celów) (Maslow 1990; Bywalec 2010, s. 20). Zdaniem autora koncepcji, kolejne potrzeby mogą być zaspokajane dopiero, kiedy zaspokojona jest potrzeba znajdująca się na niższym poziomie hierarchii.

W odniesieniu do innowacyjnych zachowań konsumentów, na akceptację i dyfuzję nowości wpływa klasyfikacja produktu ze względu na hierarchię potrzeb konsumentów. Uznanie przez konsumenta, że dany produkt zaspokaja rzeczywiście odczuwaną potrzebę, skutkuje zaangażowaniem w poszukiwanie informacji i wzbudzeniem zainteresowania. Jest więc znacznym ułatwieniem przebiegu afektywnej fazy przyjęcia innowacji. Wyższe miejsce w hierarchii potrzeb powoduje, że konsument rozważa nabycie produktu. Uświadomienie tej możliwości chroni więc przed pasywnym odrzuceniem nowości. Konsument staje się aktywny, co sprzyja ograniczeniu niejasności związanej z zakupem.

W aspekcie potrzeb innowacyjny produkt może zyskać przewagę na rynku ze względu na to, iż:

- $\quad$ w lepszy sposób zaspokaja istniejące potrzeby konsumentów;

- $\quad$ uświadamia konsumentom potrzeby niezaspokojone.

Z jednej strony działania przedsiębiorstw w tym zakresie skupiają się więc na poszukiwaniu możliwości zaspokajania potrzeb konsumentów, z drugiej - na uświadamianiu im ich istnienia. Jeżeli dana innowacja zaspokaja 
nowe potrzeby konsumentów, jej przyjęcie wywoła istotne zmiany w konsumpcji. To zaś powoduje, że zazwyczaj te grupy innowacji są wolniej przyjmowane przez rynek. Jeśli innowacja dotyczy lepszego zaspokajania już odczuwanych potrzeb, proces jej przyjęcia ulega skróceniu (Mazurek-Łopacińska 2003, s. 74).

Kolejną, psychologiczną determinantą zachowań konsumentów są ich postawy. Jest to: "określony, względnie trwały stosunek emocjonalny lub oceniający do przedmiotu, względnie dyspozycja do występowania takiego stosunku" (Rudnicki 2004, s. 102). Postawy konsumentów wobec produktu, usługi, marki mają znaczenie w kształtowaniu strategii konkurencyjnych i marketingowych przedsiębiorstw, gdyż służą przewidywaniu zachowań podmiotów na rynku (Jachnis, Terelak 1998, s. 222-223).

W omawianym kontekście przedmiotem zainteresowania stają się postawy konsumentów w stosunku do innowacyjnych produktów. Mogą mieć one charakter: pozytywny, negatywny bądź neutralny. Postawy Polaków wobec innowacji badał zespół pod kierownictwem A. Dąbrowskiej. Zgodnie z wynikami badań, prawie jedna trzecia badanych przyznała, że nie kupuje nowości wchodzących na rynek, gdyż woli sprawdzone produkty. Kolejne 27\% badanych stosunkowo rzadko kupowało nowe produkty (Dąbrowska i in. 2015, s. 125). Większa zatem część Polaków przejawia postawy zachowawcze wobec nowości na rynku. Poszukuje dóbr, które są im znajome i wobec których przyjmuje pozytywną postawę, zaś nie lubi eksperymentować z nowymi produktami. Badania prowadzone przez K. Gutowską i innych wyjaśniły ogólną negatywną postawę konsumentów wobec innowacyjnych produktów żywnościowych tym, że istnieje podejrzenie dotyczące obniżenia walorów zdrowotnych. Awersję tę eliminują jednak szczególne walory smakowe i akcentowanie, że nowości są związane z: naturalnością, świeżością, a paradoksalnie także tradycją (Gutkowska i in. 2014).

Jednocześnie warto zwrócić uwagę na fakt, iż postawy cechuje zmienność w czasie (dynamizm postaw). Trwałość jest warunkowana indywidualnie i wiąże się z cechami osobowości, nabytymi wzorcami zachowań, również z kulturą, w jakiej funkcjonują konsumenci.

Tempo akceptacji innowacji jest uzależnione od cech osobowościowych konsumentów. Osobowość w rozumieniu psychologii ekonomicznej (zwanej konsumencką) obejmuje także: "cechy osoby, bądź ludzi w ogóle, które umożliwiają wyjaśnienie spójnych wzorców zachowań" (Foxall, Goldsmith 1998, s. 151). Podział konsumentów ze względu na cechy osobowości umożliwia dokonanie segmentacji psychograficznej (Evans 1959, s. 340-369 za: Falkowski, Tyszka 2006, s. 97). 
Do cech osobowościowych, charakteryzujących konsumentów-innowatorów, zalicza się: skłonność do ryzyka, otwartość umysłu, silną potrzebę utrzymania relacji towarzyskich. A. Dąbrowska i inni, podejmując próby klasyfikacji cech osobowości konsumentów z uwagi na podejście do innowacji, wśród tych, które sprzyjają nabywaniu nowych produktów wcześniej niż inni konsumenci, wymienili - obok skłonności do ryzyka - zdolność do radzenia sobie z wysokim poziomem ryzyka i niepewności, wiarę w siebie i poleganie na sobie w nowych sytuacjach oraz niezależność w myśleniu i działaniu (Dąbrowska i in. 2015, s. 122).

Pierwszą z wymienionych cech jest skłonność do ryzyka oraz skłonność do akceptacji niejasności. Wiąże się ona z dostrzeżeniem możliwości niezaspokojenia potrzeb (nieosiągnięcia zamierzonego efektu konsumpcji) w konsekwencji dokonania niewłaściwej decyzji zakupowej. Niska skłonność do ryzyka nie służy adaptacji innowacji, zaś wysoka jest czynnikiem stymulującym. Konsumenci przejawiają pewną wewnętrzną skłonność do ryzyka oraz skłonność do akceptacji niejasności. Z drugiej strony, chodzi także o cechy samego produktu. Dostrzegane ryzyko rośnie wraz ze wzrostem ceny produktu, jego istotności dla zaspokojenia potrzeb jednostki, stopniem skomplikowania technologicznego, natomiast spada wraz ze wzrostem zamożności konsumenta. Sposobem ograniczenia ryzyka i niejasności są: zbieranie informacji, poszukiwanie opinii, zakup małych ilości produktu lub możliwość jego wypróbowania, lojalność wobec marki (Foxall, Goldsmith 1998, s. 129130).

A. Dąbrowska i inni wśród czynników, decydujących o skłonności do nabywania innowacyjnych produktów, wymienili równocześnie wiarę w siebie (Dąbrowska i in. 2015, s. 122). Zdaniem L. Garbarskiego, cecha ta ma bezpośrednie przełożenie na skłonność do ryzyka. Konsumenci, cechujący się wysokim poziomem samooceny i wiarą we własne siły, są bowiem w stanie zaakceptować wyższy jego poziom. Natomiast, osoba niepewna swych możliwości niechętnie podejmuje ryzyko (Garbarski 1998, s. 54 i nast.). Oznacza to, że osoby o wyższej wierze w siebie znamionuje wyższa skłonność do ryzyka, dzięki czemu są one gotowe do nabywania nowych produktów.

Kolejną cechą warunkującą skłonność konsumentów do nabywania produktów innowacyjnych jest niezależność w myśleniu i działaniu. Wpływ tej cechy na proces adaptacji innowacji w szerszym ujęciu społecznym nie jest jednak jednokierunkowy. Niezależność stymuluje konsumentów-innowatorów do poszukiwania informacji, wypróbowywania, a ostatecznie nabywania lub też aktywnego odrzucenia nowych produktów. W odniesieniu do procesu rozprzestrzeniania się innowacji są także istotne elementy naśladow- 
nictwa. Tym samym uzależnianie decyzji zakupowych od wpływów społecznych pozwala na przejęcie innowacji przez konsumentów wczesnych oraz grupy konsumentów mniej innowacyjnych.

Kolejną grupę uwarunkowań zachowań konsumentów stanowią czynniki demograficzne. Należy zaznaczyć, że w literaturze najczęściej są one analizowane wspólnie z determinantami społecznymi. W pewnym zakresie trudno jest bowiem rozstrzygnąć, czy dany czynnik ma charakter społeczny, czy demograficzny. W niniejszym opracowaniu wyróżniono je w celu podkreślenia istotności tej grupy uwarunkowań w procesie akceptacji innowacji. Do podstawowych cech demograficznych konsumentów, decydujących o ich innowacyjności, należą płeć i wiek.

Cechą demograficzną, która może oddziaływać na szybkość przyjmowania innowacji jest płeć. W kwestii tego wpływu kluczowy wydaje się rodzaj nabywanego dobra. Wśród dóbr typowo kobiecych ta grupa osób cechuje się wyższą innowacyjnością. Analogicznie, typowo męskie produkty innowacyjne są szybciej akceptowane przez mężczyzn. Przykładowe badania prowadzone przez P. Beaudoin i innych wskazały, że kobiety charakteryzuje większa skłonność do innowacyjnych zachowań na rynku mody. Badacze stwierdzili, iż wśród konsumentów klasyfikowanych jako innowatorzy więcej jest kobiet (Beaudoin, Lachance, Robitaille 2003). Natomiast badania D. Gonet dowiodły, że więcej innowacji jest wdrażanych w gospodarstwach rolnych prowadzonych przez mężczyzn niż kobiety. Z badanej próby $90 \%$ mężczyzn oraz 70\% kobiet przyznało, że wprowadziło innowacje w badanym okresie (Gonet 2015, s. 61).

Warto zwrócić uwagę na to, że B. Mróz zwrócił uwagę na istotną rolę homoseksualistów w upowszechnianiu innowacji. Zaliczył ich do podstawowych grup trendsetterów we współczesnym świecie. Jego zdaniem, osoby te wykazują dużą wrażliwość estetyczną, są podatne na trendy mody. Stanowią znaczny odsetek: stylistów, wizażystów, projektantów (Mróz 2013, s. 119). To zaś powoduje szczególne zainteresowanie wypróbowywaniem nowych produktów.

Kolejną zmienną demograficzną, wpływającą na zachowania konsumentów, jest wiek. Liczne badania potwierdziły, że młodzi konsumenci wyróżniają się większym poziomem akceptacji innowacji. A. Dąbrowska i inni na podstawie badań dowiedli zależności wieku od poziomu innowacyjności wśród polskich konsumentów. Skonstatowali, że dla starszej części Polaków ważne jest przyzwyczajenie do dotychczasowego stylu życia. Osoby te nie podążają za trendami mody i nie decydują się na kupowanie nowatorskich dóbr konsumpcyjnych. Z kolei, młodzi konsumenci są pozytywnie nastawieni do nowości rynkowych (Dąbrowska i in. 2015, s. 131). To właśnie oni stano- 
wią grupę konsumentów-innowatorów. Badania w tym zakresie przeprowadził między innymi T. Laukkanen. Dowiodły one, że takie prawidłowości dominują na rynku bankowości elektronicznej. Różnice te w dużej mierze wynikają z niskiego zaufania osób starszych do nowoczesnych technologii (Laukkanen, Sinkkonen, Kivijärvi, Laukkanen 2007).

Badania prowadzone przez S. Badowską postulują jednak zwrócenie uwagi również na segment konsumentów-seniorów w procesie kreowania innowacji, choć jednocześnie autorka skonstatowała, że seniorzy wykazują pewne trudności w procesie przetwarzania nowych, złożonych informacji i nabywania nowych umiejętności, przykładowo związanych z obsługą nowoczesnych technologii czy realizacją zakupów w sieci (Badowska 2016, s. 6970). Może to wynikać z przywiązania do: tradycji, wysokiej potrzeby bezpieczeństwa, niskiej skłonności do ryzyka oraz potrzeby wsparcia personalnego w procesie zakupowym.

Niemniej możliwe jest spojrzenie na konsumentów-seniorów w procesie kreowania innowacji jako na potencjał rynkowy. Badania dowiodły, że konsumenci-seniorzy posiadają większe doświadczenie rynkowe, szybciej kształtują opinię o produkcie, są bardziej krytyczni wobec innowacji, w większym stopniu są skłonni porównywać oferty obecne na rynku, preferują komunikację bezpośrednią. Takie prawidłowości zachowań - w odniesieniu do dynamicznych zmian demograficznych społeczeństwa - stają się wyzwaniem w działalności innowacyjnej i marketingowej przedsiębiorstw. Z badań Badowskiej również wynika, że polscy konsumenci-seniorzy przejawiają zróżnicowane postawy w stosunku do innowacji technologicznych, co oznacza że traktowanie tego segmentu rynkowego jako względnie homogenicznego i odrzucającego innowacje może nie być właściwe (Badowska 2016, s. 71-80).

Kolejną zmienną, wpływającą na innowacyjność konsumentów, jest miejsce zamieszkania. Duże aglomeracje miejskie sprzyjają rozprzestrzenianiu się innowacji produktowych. Badania prowadzone przez G. Maciejewskiego potwierdziły to, że konsumenci mieszkający w miastach w większej mierze przejawiają pozytywne postawy wobec innowacji, zaś konsumenci mieszkający na wsi - postawy neutralne. Największymi zwolennikami innowacji okazali się mieszkańcy miast powyżej 200 tys. mieszkańców. Co więcej, mieszkańcy miast częściej kojarzyli posiadanie innowacyjnych produktów z: prestiżem, lepszym zaspokojeniem potrzeb konsumpcyjnych, większą wydajnością i oszczędnością czasu. Mieszkańcy wsi łączyli innowacyjne produkty z: wyższą ceną, niższą relacją jakości do ceny oraz negatywnym wpływem na zdrowie (Maciejewski 2015, s. 953-959). Ustalenia te uwierzytelniły badania. Dąbrowskiej i innych. Zgodnie z nimi, najwyższą skłonnością do nabywania innowacyjnych dóbr cechują się osoby mieszkające w większych 
miastach (Dąbrowska i in. 2015, s. 131). Na tej podstawie należy zauważyć, że znaczenie zmiennej miejsca zamieszkania może być związane z czynnikiem kulturowym oraz średnią wieku mieszkańców miast i wsi.

Kolejną grupą czynników decydujących o innowacyjności konsumenckiej są uwarunkowania społeczne. Jednostka w procesie gospodarowania jest podatna na wpływy otoczenia, sama również na nie oddziałuje. Do podstawowych grup społecznych, kształtujących zachowania konsumentów, zalicza się: rodzinę, grupę odniesienia i klasę społeczną.

W obszarze wpływów społecznych należy wyodrębnić wpływ normatywny i informacyjny. Pierwszy z wymienionych występuje, gdy otoczenie społeczne determinuje zachowania konsumenta, dostarczając mu wzorców do naśladowania. Z kolei oddziaływanie informacyjne ma miejsce, gdy członkowie grup społecznych przekazują konsumentowi informacje w postaci porad i opinii, którymi konsument kieruje się, dokonując zakupu (Burgiel 2014, s. 47). W procesie akceptacji innowacji przez konsumentów ujawniają się obie formy wpływu.

W analizie wpływów społecznych na akceptację innowacji przez konsumentów ważne miejsce zajmuje widoczność konsumpcji. Większą siłę oddziaływania otoczenia społecznego można zaobserwować w odniesieniu do dóbr konsumowanych publicznie. Siła wpływów społecznych jest mniejsza w przypadku produktów konsumowanych prywatnie. Upraszczając, można spodziewać się, że konsumenci w większej mierze są skłonni kierować się wpływem społecznym przy zakupie płaszcza niż bielizny. Istotną kwestią jest także luksusowość dobra. Dobra podstawowe wyróżnia mniejsza siła wpływu społecznego niż dobra uznawane za luksusowe. Jednocześnie Burgiel dowiódł, że dobra podstawowe konsumowane publicznie cechuje większy wpływ społeczny niż dobra luksusowe konsumowane prywatnie (Burgiel 2014, s. 60). Widoczność konsumpcji staje się więc jednym z czynników przesądzających o sile wpływu społecznego na proces decyzyjny. Innowacyjne produkty mogą mieć zarówno charakter dóbr luksusowych, jak i podstawowych. Równocześnie mogą być konsumowane zarazem publicznie, jak i prywatnie. Przedsiębiorstwo, wdrażając innowacje, powinno brać pod uwagę to, iż siła wpływu konsumentów-innowatorów na otoczenie jest większa, gdy dobro jest konsumowane publicznie oraz gdy ma charakter luksusowy.

Wśród determinant zachowań konsumentów istotne miejsce zajmuje wpływ rodziny jako grupy społecznej, którą tworzą najczęściej osoby połączone związkiem małżeńskim bądź rodzicielskim (Światowy 2006, s. 113). Oddziaływanie rodziny na zachowania konsumentów ujawnia się poprzez cykl życia rodziny i naśladownictwo. Nawyki praktykowane w rodzinie są 
przejmowane przez jej członków. Związek między rodziną a innowacyjnymi wzorcami konsumpcji były przedmiotem badań prowadzonych przez J. Cotte i S.L. Wood. Wskazano w nich, że związek ten ma charakter dodatni i jest silny oraz, że dzieci mają większy wpływ na adaptację wzorców konsumpcji przez rodziców niż przez rodzeństwo. Wynika to z procesu socjalizacji w zakresie konsumpcji (Cotte, Wood 2004).

Zmiany stylów konsumpcji są również ściśle powiązane z procesem starzenia się społeczeństwa. Wraz ze zmianą cyklu życia rodziny zmianie ulegają jej wzory konsumpcyjne. Młode osoby, tworzące jednoosobowe gospodarstwa domowe, zazwyczaj przejawiają większe zainteresowanie wyglądem i rozrywką. Są bardziej podatne na modę i chętne do zakupu innowacyjnych produktów. Wzory konsumpcji ulegają zmianie po zawarciu związku małżeńskiego. Rośnie część dochodu przeznaczana na dobra trwałego użytku. Nadal duże znaczenie mają rozrywka i usługi wypoczynkowe. Wzory te zmieniają się wraz z przyjściem dzieci na świat. Skupienie na zaspokajaniu potrzeb rodziny powoduje obniżenie zainteresowania życiem towarzyskim. Wydatki głównie obejmują: żywność, zabawki dla dzieci, odzież i nadal dobra trwałego użytku. Wraz z dorastaniem dzieci sytuacja finansowa rodziny zazwyczaj ulega poprawie. Gospodarstwo domowe przeznacza większą część dochodów na rozrywkę, w tym: podróże, środki transportu, nowe meble, środki ochrony zdrowia (Światowy 2006, s. 108-109). Tym samym proces adaptacji innowacji zależy od siły oddziaływania potrzeb w określonych fazach cyklu życia rodziny. Konsumenci są w stanie akceptować te innowacje, które aktualnie odpowiadają potrzebom ich gospodarstwa domowego.

Konsument często wzoruje swoje zachowania na grupie odniesienia, jaką podziwia, do której aspiruje czy też takiej, której członków uznaje za ekspertów w danej dziedzinie. Grupa odniesienia to: „jednostka bądź zbiór ludzi, dzięki którym człowiek kształtuje swoje postawy, przekonania, wartości i zachowanie" (Foxall, Goldsmith 1998, s. 238). Grupa ta jest źródłem wzorców konsumpcji. Jednostka dąży do posiadania dóbr uznawanych w grupie za prestiżowe, często w celach demonstracyjnych. Jednocześnie naśladuje i kieruje się opiniami grupy, która stanowi dla niej odniesienie w sferze konsumpcji. Szczególnym typem grupy odniesienia są tzw. liderzy opinii, autorytety w określonej dziedzinie, od których pozostali członkowie danej grupy przejmują określone trendy (Światowy 2006, s. 111). Rolę liderów opinii wzmacnia niewiedza konsumenta. W warunkach niejasności konsument uznaje pogląd grupy odniesienia czy autorytetu za słuszny (Foxall, Goldsmith 1998, s. 239).

Grupa odniesienia i liderzy opinii wywierają istotny wpływ na postawy konsumentów wobec nowości dzięki wcześniejszemu zapoznaniu się z pro- 
duktem oraz rozpowszechnianie się informacji na jego temat (MazurekŁopacińska 2003, s. 67). Pozytywny odbiór nowości przez grupę odniesienia nadaje produktom pewną wartość symboliczną, wzbudza zainteresowanie, jest źródłem informacji i pozwala mentalnie ograniczyć poziom niepewności dotyczącej zakupu. Wpływ grupy odniesienia na decyzje związane z nabywaniem nowego produktu był przedmiotem badań A. Dąbrowskiej i innych. Zgodnie z uzyskanymi wynikami, posiadanie określonego dobra konsumpcyjnego przez otoczenie okazywało się ważne przy zakupie danego produktu dla co czwartego badanego. Tym samym badania wykazały istnienie wpływu normatywnego. Podobnie, badania ujawniły istnienie wpływu informacyjnego. Co piąty respondent (21\%) deklarował, iż nabywając nowe produkty, bierze pod uwagę opinię znajomych (Dąbrowska i in. 2015, s. 133).

Czynnikiem, wpływającym na zachowania konsumentów, może być również poziom ich wykształcenia. Jednocześnie należy zaznaczyć, iż w literaturze nie ma pełnej zgody co do tej zależności. Przykładowo, badania prowadzone przez K. Gutkowską w zakresie innowacyjności konsumentów wobec produktów żywnościowych wskazały, że ponad 30\% konsumentów z wykształceniem wyższym, niecałe $12 \%$ z wykształceniem podstawowym i około $20 \%$ z pozostałym poziomem wykształcenia kupuje nowy produkt stosunkowo szybko, choć po pewnym namyśle. Z kolei, niemal 11\% osób z wykształceniem wyższym przy około 18-19\% konsumentów pozostałych grup wykształcenia kupuje nowy produkt, gdy większość znajomych już go nabyła i pozytywnie oceniła (Gutkowska 2011, s. 112). Analogicznie, badania prowadzone przez A. Dąbrowską i innych wykazały, że konsumenci, którzy przejawiają pozytywny stosunek do nowości rynkowych, w większości mają wyższe wykształcenie (Dąbrowska i in. 2015, s. 125). Badania, które realizowała A. Przewoźna-Skowrońska pod względem skłonności konsumentów do sięgania po innowacyjne produkty na rynku dań gotowych, dowiodły, że największą część innowatorów stanowią osoby z wykształceniem średnim. Jednak wśród osób z wykształceniem wyższym największy był odsetek osób kupujących nowość po namyśle (ponad 30\%, przy ponad 20\% konsumentów z wykształceniem średnim oraz niemal $12 \%$ z wykształceniem podstawowym) (Przewoźna-Skowrońska 2015, s. 1320). Przedstawione różnice wydają się wynikać z dwóch czynników. Pierwszym z nich jest rodzaj analizowanej innowacji, drugim zaś sposób przyjęcia skali oceny szybkości przyjmowania innowacji w badaniach. Ogółem - opierając się na teorii dyfuzji innowacji, jak również na wynikach badań wśród polskich konsumentów - można stwierdzić, iż wyższe wykształcenie konsumentów zazwyczaj sprzyja rozprzestrzenianiu się innowacji. 
Kolejną determinantą zachowań konsumentów jest wykonywany zawód. Przedstawiciele pewnych profesji są określani jako innowatorzy oraz trendsetterzy. Zdaniem A. Dąbrowskiej i innych, status zawodowy jest ważnym czynnikiem różnicującym innowacyjne zachowania konsumentów. Związane jest to z przypisaniem określonym zawodom miejsca w strukturze społecznej. Prowadzone badania wskazały, że innowacyjnymi konsumentami były w większości osoby pracujące na własny rachunek i pracownicy administracyjno-biurowi. Przewaga konsumentów tradycyjnych, niechętnych do nabywania innowacyjnych produktów, zarysowała się w grupie rolników oraz emerytów i rencistów (Dąbrowska i in. 2015, s. 125). Niewątpliwie, wyjaśnieniem takich rozbieżności w grupie rolników jest miejsce pochodzenia. Jak bowiem stwierdzono, osoby mieszkające na wsiach są mniej skłonne do akceptacji innowacji. W grupie emerytów i rencistów czynnikiem decydującym jest wiek.

B. Mróz, analizując strukturę trendsetterów na rynku dóbr konsumpcyjnych, skonstatował, że innowacyjnymi konsumentami przede wszystkim są: projektanci, artyści, celebryci. Zazwyczaj projektantów cechuje wrażliwość na zmiany w modzie, w związku z czym chętnie sięgają oni po nowe produkty i w projektach starają się wyprzedzać rynek w procesie kreowania nowych trendów. Artyści jako propagatorzy trendów poszukują nowości, nie boją się odmienności, są otwarci na nowe style zachowań i konsumpcji, często eksperymentują i przejawiają wysoką skłonność do ryzyka. Z kolei, celebryci, jako osoby świata show biznesu, są wzorem do naśladowania w wielu grupach odbiorców (stanowią grupę odniesienia, liderów opinii). Odgrywają rolę medium przekazu trendów konsumpcyjnych. Wpływ na kreowanie trendów przez tę grupę wzmacnia relacjonowanie ich życia przez media (Mróz 2013, s. 119).

Powyższe rozważania prowadzą do wyodrębnienia kolejnego czynnika, który oddziałuje na skłonność konsumentów do akceptacji innowacji. Jest nim dążenie do osiągnięcia prestiżu za sprawą demonstracyjnego dokonywania zakupów. Niejednokrotnie źródłem prestiżu są produkty modne, droższe, uznanych marek. G. Światowy dowiódł, że współcześnie konsumenci często dążą do uzyskania prestiżu za pomocą nowych metod, do jakich należy tzw. demonstracyjny rozsądek. Tym samym starają się pokazać społeczeństwu, jak mądrze postępują podczas zakupów (w tym nabywając produkty ekologiczne, przyjazne dla środowiska i zdrowia). Mogą również zmierzać do uzyskania prestiżu przez demonstrację własnej indywidualności (Światowy 2006, s. 112-113).

Ze względu na możliwość uzyskania prestiżu, atrakcyjność dóbr innowacyjnych jest najwyższa w fazie wprowadzania na rynek. Słabnie zaś 
w momencie przyjęcia innowacji przez tzw. wczesną większość. Według badań A. Dąbrowskiej i innych, cechą innowacyjnych konsumentów była właśnie chęć posiadania nowego produktu przed innymi osobami. Dotyczyło to głównie osób młodych, w wieku 18-29 lat (Dąbrowska i in. 2015, s. 125).

Współcześnie, w świetle procesów globalizacyjnych, istotny staje się również wpływ kultury na kształtowanie wzorów konsumpcji. Przez pojęcie kulturowo powiązanych wzorów konsumpcji za F. Bylokiem: „będziemy rozumieć takie wzory, które są typowe dla danego kręgu kulturowego" (Bylok 2005, s. 146). Są to pewne sposoby zachowań konsumpcyjnych uznawane w danej kulturze za poprawne. Nowo wprowadzane produkty mają szansę na pozyskanie znaczenia kulturowego dopiero po długim okresie obecności na rynku. Proces kulturowego przyswajania produktów jest czasochłonny. Stąd silne przywiązania kulturowe w społeczeństwach zazwyczaj są postrzegane jako bariera innowacyjności.

Z punktu widzenia kulturowych uwarunkowań innowacyjności konsumentów są istotne zmiany, jakie zaszły w społeczeństwie polskim w okresie transformacji. Jak wskazała E. Gruszewska, w latach siedemdziesiątych i osiemdziesiątych XX wieku społeczeństwo polskie charakteryzowały: bierność i zachowawczość, podatność na zewnętrzne kierowanie, nastawienie na realizację wspólnych celów, unikanie ryzyka. Takie postawy Polaków nie sprzyjały przyjmowaniu innowacji, jednocześnie w okresie tym innowacje rynkowe nie były popularnym przedmiotem obrotu detalicznego. Okres transformacji wpłynął na zmianę wzorców zachowań i stylów życia Polaków. Od początku lat dziewięćdziesiątych jest obserwowana ekspansja aktywności i rozwój postaw przedsiębiorczych. Jak stwierdziła E. Gruszewska: "nowe warunki ustrojowe wzmocniły ducha indywidualizmu, aktywności, prywatnej zapobiegliwości i kreatywności, nastąpiła eksplozja różnorodnych form zaradności" (Gruszewska 2013, s. 207). Zmiany gospodarcze doprowadziły do szeregu zmian kulturowych, w tym wpłynęły na: rozwój trendów aktywności, otwartości, samodecydowania, poczucia kontroli i wzrost skłonności do ryzyka. Łącznie zmiany te służyły innowacyjnym postawom konsumentów. Co więcej, w okresie tym w Polsce upowszechniły się postawy związane z dążeniem do samorealizacji, w tym z dążeniem do podnoszenia własnych kompetencji i zdobywania wykształcenia wyższego, co również przyczyniło się do większej aktywności rynkowej oraz otwartości na nowości, w tym technologiczne.

Społeczeństwa, które pozwalają na większą różnorodność zachowań, doświadczają szybszych przyjęć nowych produktów. W kulturach zamkniętych rozprzestrzenianie się innowacyjnych wzorców konsumpcji następuje powoli. Struktury te cechuje bowiem względnie stała przynależność jedno- 
stek do klas i warstw społecznych. Otwarta struktura sprzyja rozprzestrzenianiu się innowacji, w szczególności szybkiemu ich przenikaniu z klas wyższych do niższych (Dąbrowska i in. 2015, s. 117).

Istotnym czynnikiem, warunkującym skłonność konsumentów do sięgania po innowacje rynkowe, jest moda, która będąc: „instrumentem przekazu kulturowego, nadaje nowe lub zmienia stare znaczenie kulturowe dobrom konsumpcyjnym" (Bylok 2005, s. 236). Moda wyznacza kierunki zmian zachowań konsumentów. W odniesieniu do innowacji znaczenie ma możliwość wykreowania mody na dany produkt w momencie wprowadzania go na rynek. K. Mazurek-Łopacińska zauważyła, że moda pobudza pogoń za nowymi produktami, a także stylami konsumpcji nie tylko w zakresie ubioru, lecz również urządzenia mieszkania, budownictwa i architektury, produktów codziennego użytku (Mazurek-Łopacińska 2015, s. 27). Do rozpowszechniania się wzorów konsumpcji dochodzi dzięki popularyzacji produktów wśród trendsetterów, za jakich mogą być uważane: osoby medialne, celebryci, a zarazem osoby zamożne, liderzy opinii. W społeczeństwie moda zazwyczaj jest popularyzowania przez klasy wyższe i przenika w dół (Dąbrowska i in. 2015, s. 117). Tym samym większa podatność konsumentów na zmianę trendów mody jest czynnikiem sprzyjającym akceptacji innowacji (Bylok 2005).

Konsumenci, podążający za trendami mody, stanowią więc grupę innowatorów. Innowacyjność mody powoduje rozpowszechnianie innowacyjnych produktów. Według badań A. Dąbrowskiej i innych, 29\% badanych dokonuje zakupu nowego produktu ze względu na zgodność z trendami mody (Dąbrowska i in. 2015, s. 132-133). Jak wskazali J. Kang i H. Park-Poaps (Kang, Park-Poaps 2010), innowacyjność mody wiąże się z motywami hedonistycznymi i dążeniem do odczuwania przyjemności. Jednak negatywnie kojarzy się ją z użytkowymi walorami decyzji.

Ważnym elementem kultury są normy i wartości, czyli pewne poglądy na temat zachowania akceptowanego, głoszące, co jest uznane, a co nie przez daną kulturę. Są one trwałymi przekonaniami dotyczącymi pożądanych zachowań oraz stanów przyszłości, choć wartości akceptowane przez społeczeństwo mogą ulegać modyfikacji. W ostatnim czasie obserwuje się stopniowy spadek znaczenia wartości materialnych. Rośnie znaczenie: samorealizacji, rozwoju osobistego, wolnego czasu i dbałości o środowisko. Przedsiębiorstwo, kreując innowacje, powinno zastanowić się, w jakim stopniu odpowiadają one normom społecznym. Przykładowo, wartością cenioną w danym społeczeństwie może być dbałość o ochronę środowiska, co skłania przedsiębiorstwa do generowania artykułów przyjaznych dla otoczenia, energooszczędnych i wodooszczędnych, a także opakowań, które są łatwo asymilowane w środowisku (Nowak 1995, s. 59-63). 
Cena produktu jest jednym z najistotniejszych elementów, na jakie zwraca uwagę konsument w momencie zakupu. Zależność między ceną a popytem zwykle jest odwrotnie proporcjonalna. W kontekście innowacji ważny jest spadek skłonności do ryzyka pod wpływem wzrostu ceny. Ogółem wysoka cena zniechęca do nabywania innowacyjnych produktów. Istotność znaczenia tego czynnika w procesie nabywania nowych produktów ujawniły badania A. Dąbrowskiej i innych. Zgodnie z uzyskanymi wynikami, przy nabywaniu nowego produktu cena była istotnym kryterium wyboru dla 92\% respondentów (przy czym dla 69\% „zdecydowanie ważna”) (Dąbrowska i in. 2015, s. 132). Faktyczna reakcja konsumentów na ceny produktów jest jednak bardziej złożona. Ludzie często traktują cenę jako odzwierciedlenie jakości produktu bądź nabywanie drogich rzeczy jest dla nich źródłem prestiżu (Rudnicki 2004, s. 144).

Duże znaczenie ma kategoria dochodu konsumentów, który warunkuje możliwość zaspokajania potrzeb, a co za tym idzie, dokonywania zakupów. Jak wskazali P.P. Saviotti i A. Pyka, odpowiedni dochód jest jednym z dwóch wyodrębnionych, podstawowych czynników decydujących o akceptacji innowacji przez konsumentów. Stwierdzili oni, że przede wszystkim konsumenci muszą posiadać dochody na poziomie umożliwiającym im nabywanie innowacyjnych produktów (Saviotti, Pyka 2016, s. 5). Według badań zespołu A. Dąbrowskiej, konsumenci, którzy przejawiają pozytywny stosunek do nowości rynkowych, to w większości osoby osiągające zarobki powyżej przeciętnej (Dąbrowska i in. 2015, s. 126). Wysoki poziom zamożności obniża relatywne poczucie ewentualnej straty w przypadku, gdy produkt nie zaspokaja potrzeb konsumenta w oczekiwanym stopniu. Podobną zależność zauważył B. Mróz. Jego zdaniem, osoby o wysokich dochodach w większej mierze są trendsetterami, demonstrują style zachowań, otwartość na nowości (Mróz 2013, s. 119), co sprzyja przyjęciu przez nich innowacji, a następnie umożliwia ich wpływ na grupy naśladowców.

Interesującym obszarem wpływu na skłonność konsumentów do akceptacji innowacji rynkowych jest podaż innowacyjnych produktów. Wysoka konkurencja rynkowa prowadzi do trudności w zakresie porównań, a w następstwie podejmowania decyzji konsumenckich. Pojawia się zjawisko, zwane w literaturze paradoksem wyboru. Zgodnie z nim, kiedy konsumenci są postawieni przed problemem wyboru spośród wielu konkurujących ze sobą produktów, odwlekają decyzję. Kwestia ta była przedmiotem badań prowadzonych przez B. Shwartza (Szwartz 2004). Z tego względu adaptacja innowacji na rynku silnie konkurencyjnym przy znacznej liczbie produktów zaspokajających tę samą potrzebę - chociażby w inny sposób - utrudnia proces akceptacji innowacji przez konsumentów. 
Zasadnicze znaczenie w akceptacji innowacji, zwłaszcza w fazie wprowadzania produktu na rynek, mają czynniki marketingowe. W fazie tej bowiem konsument, aby podjąć decyzję, musi zapoznać się z cechami produktu. Główną rolę odgrywają tu informacje o produkcie oraz jego atrybutach. Zakres gromadzonych informacji pozwala na ograniczenie odczuwanego poziomu niejasności, co sprzyja podjęciu decyzji.

Istotność dostępu do informacji potwierdziły badania A. Dąbrowskiej i innych. Wykazały one, iż konsumenci-innowatorzy cechują się wyższą aktywnością w poszukiwaniu informacji niż pozostałe grupy konsumentów (w specjalistycznych czasopismach, Internecie). Dla znacznej części badanych (27\%) podstawowym źródłem informacji były jednak reklama i półki sklepowe. Informacji o nowościach rynkowych w sieci poszukiwało $14 \%$ badanych respondentów. Takie wyniki badań skłoniły do wniosku, iż polscy konsumenci ogólnie przejawiają pasywną postawę wobec poszukiwania informacji i są podatni na sugestie producentów (Dąbrowska i in. 2015, s. 125-127).

Czynnikiem, wyznaczającym akceptację innowacji przez konsumentów, są cechy produktów. W ich zakres wchodzą cechy materialne - nadawane na etapie produkcji - znak towarowy, opakowanie, usługi towarzyszące sprzedaży. O tym, w jakim stopniu dany towar jest w stanie zaspokajać potrzeby konsumentów, decydują właśnie cechy materialne (Rudnicki 2004, s. 153). Badania A. Dąbrowskiej i innych wskazały, że przy kupowaniu nowego produktu największe znaczenie dla konsumentów ma funkcjonalność użytkowa (94\%, w tym 74\% „zdecydowanie ważne") i wysoka jakość (94\%, w tym 72\% "zdecydowanie ważne"). Pożądaną przez konsumentów-innowatorów cechą nowych produktów jest ich unikalność. Niemal $80 \%$ badanych uznało za ważny czynnik, determinujący nabycie nowości, dostosowanie do indywidualnych potrzeb (,szyte na miarę", "dostosowane do moich potrzeb i sylwetki"). Kolejną cechą, pożądaną przez konsumentów-innowatorów, jest oryginalny i atrakcyjny wygląd produktu. Cechę tę za istotną uznał co trzeci badany (Dąbrowska i in. 2015, s. 130-132).

Badania dowiodły, że istnieje związek między skłonnością do nabywania innowacji a rodzajem produktu. Generalnie, konsumenci przejawiają pozytywny stosunek do innowacji, które sprzyjają wygodzie użytkowania oraz zapewniają większą jakość. Istnieją jednak grupy produktów, w stosunku do których innowacyjność jest mniej pożądana. Do takich należą produkty żywnościowe. Innowacyjne produkty żywnościowe często są postrzegane jako bardziej przetworzone, o mniejszej ilości substancji odżywczych. Analogicznie, pozytywnie jest odbierane to, że innowacyjny produkt posiada dodatkowe walory, w tym zdrowotne, jest wzbogacony o dodatkowe składniki. Konsumenci przejawiają również niższy poziom innowacyjności wobec 
produktów tradycyjnych, do jakich należy chleb. Zmiany takich produktów są kojarzone z utratą tradycyjnych walorów i wartości (Gutowska 2011; Gutowska i in. 2009). Poziom innowacyjności konsumentów jest wyższy w odniesieniu do produktów o krótkich cyklach życia na rynku, w tym w szczególności do sprzętu elektronicznego, poddawanych stałym zmianom technologicznym. Do takich należą: telefony komórkowe, sprzęt komputerowy, sprzęt AGD (Szul 2016, s. 230).

Wśród cech produktów istotne znaczenie dla przyjmowania nowości przez konsumentów ma zaawansowanie technologiczne. Jeżeli produkt jest bardzo złożony pod względem technologicznym, proces decyzyjny ulega skomplikowaniu. Produkty złożone technologiczne są postrzegane w kategoriach niejasności zakupu. Z kolei, zakup produktu o prostych i jednoznacznych cechach, nawet jeśli jest innowacyjny i dopiero pojawił się na rynku, może być postrzegany jako pewny (Domurat, Zieliński 2013, s. 33).

Istotne znaczenie $\mathrm{w}$ procesie akceptacji innowacji ma także marka, będąca elementem produktu. Ph. Kotlera markę zdefiniował jako: "nazwę, znak, symbol, wzór lub kombinację tych elementów, stworzoną w celu rozpoznania towarów i usług konkurentów" (Kotler 2005, s. 421). Konsumenci przejawiają skłonność do budowania postaw lojalnościowych wobec marek produktów. Oznacza to, że nabywają stale te same produkty i niechętnie zmieniają przyzwyczajenia (Falkowski, Tyszka 2006, s. 170-178). Znacząco ułatwia to proces decyzyjny, skraca go i angażuje mniej zasobów poznawczych. Lojalność wobec marki zdecydowanie upraszcza więc proces podejmowania decyzji konsumenckich.

Zjawisko przywiązania do marki może mieć pozytywny i negatywny wpływ na akceptację innowacji. Z jednej strony, przywiązanie do marki i grupy produktów powoduje niechęć do zmiany. Z drugiej strony, wdrażanie nowych produktów pod znaną marką może skracać proces ich adaptacji.

Kolejnym czynnikiem kluczowym w kształtowaniu skłonności konsumentów do akceptacji innowacji rynkowych jest dystrybucja produktów. Obejmuje ona: działalność polegającą na pokonywaniu przestrzennych, czasowych, ilościowych i asortymentowych różnic między sferą produkcji a sferą finalnej konsumpcji, sposób rozmieszczania produktów na rynku oraz docierania do konsumentów (Kramer 2004, s. 111-113). Celem dystrybucji jest zatem zapewnienie konsumentowi jak najlepszej dostępności produktów. Sposób dystrybucji warunkuje łatwość nabycia produktu i jego obecność na półkach sklepowych. Dostępność produktów zwiększa tempo akceptacji innowacji na rynku. Możliwość osobistego kontaktu z produktem przed nabyciem ogranicza poczucie niepewności. Powoduje, że konsument może być 
pewny co najmniej jego podstawowych cech fizycznych (Domurat, Zieliński 2013, s. 33).

Podsumowując, na skłonność konsumentów do akceptacji innowacji rynkowych na rynku wpływa szereg czynników, wśród których można wskazać czynniki psychologiczne i demograficzne (rozpatrywane przez pryzmat jednostki), społeczne i kulturowe (analizowane w stosunku do szerszych grup odbiorców), a także marketingowe, dotyczące cech produktu. Istotną kategorią - odnoszącą się zarówno do cech: indywidualnych, grupowych, jak i związanych z produktem - są determinanty ekonomiczne. 


\section{ROZDZIAt 3. \\ Zachowania konsumentów w procesie kreowania innowacji}

\subsection{Miejsce konsumenta w procesie kreowania innowacji przez przedsiębiorstwa}

Obok wpływu innowacji na wzorce konsumpcji, można wskazać wpływ konsumpcji na działalność innowacyjną przedsiębiorstw. Kategoria użytkowników jest wskazywana jako źródło innowacji w większości modeli innowacji. Kwestię tę omawiali autorzy kluczowych koncepcji innowacji, w tym: P.F. Drucker (1992, s. 43), D. Smith (2006, s. 88), W.M. Cohen i D.A. Lewinthal (1990, s. 128), K. Nordström i M. Biaström (2002, s. 713-723).

P.F. Drucker stwierdził, że bodźcem do powstawania innowacji nie musi być czynnik technologiczny. Rolę tę może odgrywać obserwacja rynku oraz zmian, jakie zachodzą w sferze konsumpcji. Tym samym źródłem innowacji mogą stać się: postawy społeczne, zachowania konsumpcyjne, trendy zachowań konsumentów, zmiany w zakresie ich potrzeb (Drucker 1992, s. 43).

Teoria zdolności absorpcyjnej - autorstwa W.M. Cohena i D.A. Lewinthala - wskazuje, że powstawanie innowacji opiera się na bazie zewnętrznych (związanych z technologią) oraz wewnętrznych (związanych z organizacją) uwarunkowań. O innowacyjności przedsiębiorstwa decyduje jego zdolność do rozpoznawania wartości zewnętrznych informacji oraz wykorzystywania ich w działalności innowacyjnej. Kanał przepływu informacji między środowiskiem a przedsiębiorstwem determinuje jego zdolność absorpcyjną (Cohen, Lewinthal 1990, s. 128). Jednym z elementów środowiska zewnętrznego generującego informacje, absorbowane przez przedsiębiorstwo w procesie kreowania innowacji, jest wiedza o potrzebach odbiorców.

W teorii dominującego modelu podstawową rolę w kreowaniu innowacji przypisano użytkownikom. Według teorii K. Nordströma i M. Biaströma, w określonym czasie w gospodarce dominuje modelowa konfiguracja produktu, skuteczna pod względem konkurencyjnym. W efekcie większość przedsiębiorstw rynkowych, kreując innowacje, podąża za tym modelem (Nordström, Biaström 2002, s. 713-723). W.J. Abernathy i J.M. Utterback wyróżnili trzy podstawowe czynniki decydujące o dominacji danego modelu. Pierwszym z nich są preferencje klientów i ich przekonanie o odpowiednim zaspokajaniu potrzeb przez daną konfigurację produktu. Drugim wskazanym 
czynnikiem jest siła rynkowa dominującego konkurenta, trzecim zaś - regulacje prawne (Abernathy, Utterback 1978, s. 40-47). Tym samym istotna staje się zdolność innowacji do zaspokajania potrzeb użytkowników.

Miejsce konsumenta w kształtowaniu innowacji na przestrzeni rozwoju teorii innowacji doskonale obrazuje klasyfikacja pięciu generacji modeli innowacji R. Rothwella (Rothwell 1994). Model podażowy dominujący w podejściu do kształtowania innowacji w latach trzydziestych-sześćdziesiątych $\mathrm{XX}$ wieku, zwany również modelem innowacji pchanej przez naukę lub modelem pierwszej generacji, kładł nacisk na możliwości dostarczenia innowacji na rynek, nie przywiązując znacznej wagi do strony popytowej. Zgodnie z nim, podaż innowacji głównie była generowana przez wiedzę, skłonność ludzi do poszukiwania ciągle nowych rozwiązań, a podstawą ich kreowania były: kwalifikacje, kreatywność kadry naukowo-badawczej i wyposażenie (Ciborowski 2004, s. 22).

Rosnące nasycenie rynku produktami konsumpcyjnymi wymusiło zmianę podejścia do innowacji. Koncepcja podażowa z czasem zaczęła ustępować koncepcji popytowej innowacji (model drugiej generacji). W modelu za priorytetowe uznano rozpoznanie potrzeb i preferencji potencjalnych nabywców. Zarówno modele: podażowy, jak i popytowy należały do liniowych modeli innowacji. W latach siedemdziesiątych XX wieku stopniowo zaczęły być one zastępowane modelami nieliniowymi, o wyższej złożoności, uwzględniającymi sprzężenia zwrotne między elementami modelu.

Model interakcyjny, zwany modelem trzeciej generacji lub modelem sprzężonym, opierał się na uzyskaniu efektu synergii między czynnikami popytowymi a podażowymi. Zgodnie z nim, innowacje powinny być dostosowane do potencjalnych nabywców i postrzeganych przez nich korzyści. Nowe potrzeby konsumpcyjne posiadają więc potencjał innowacyjny.

Z czasem - zwłaszcza w krajach wysoko rozwiniętych - rozwinął się model zintegrowany, zwany modelem czwartej generacji. Wskazywał on na sprzężenia zwrotne między możliwościami technicznymi a potrzebami konsumenckimi oraz interakcje między nauką, techniką a działaniami wdrożeniowymi wewnątrz przedsiębiorstwa. Obecnie za dominujący można uznać model symultaniczny, zwany również sieciowym (model piątej generacji), w którym następuje dalszy wzrost znaczenia powiązań hybrydowych, charakterystycznych dla modelu zintegrowanego. Model ten uwzględnia czynniki popytowe kształtowania innowacji (Gardocka-Jałowiec 2015b, s. 16-28).

Ogółem więc rola konsumenta w kreowaniu innowacji została pominięta jedynie w modelu innowacji pierwszej generacji. Kolejne modele wdrażania innowacji brały pod uwagę stronę popytową, a zwłaszcza preferencje nabywców w procesie kreowania innowacji i dostarczania ich na rynek. 
Jednocześnie dążenie przedsiębiorstw do dostosowania produktów i usług do potrzeb i preferencji odbiorców na każdym etapie cyklu życia produktu jest kosztogenne. K. Galbraith zwrócił uwagę na zjawisko, zwane odwróconą sekwencją (Galbraith 1973). Jego zdaniem, tradycyjna sekwencja dotyczy sytuacji, w której przedsiębiorstwa pasywnie odpowiadają na popyt zgłaszany przez konsumentów. Duże przedsiębiorstwa, działające w globalnej gospodarce, są zmuszone przeznaczać znaczne nakłady finansowe na działalność badawczo-rozwojową, uznając wiedzę za podstawowy czynnik konkurencyjności. Ten elitarny model innowacji generuje wysokie koszty, wiąże się z wysokim ryzykiem oraz nie gwarantuje uzyskania wysokiej stopy zwrotu z inwestycji. Przedsiębiorstwa starają się więc przejąć kontrolę nad rynkiem dzięki tzw. odwróconej sekwencji. W miejsce analizy zgłaszanego popytu za pomocą narzędzi marketingowych starają się ten popyt kreować. T. Poskrobko i A. Zielińska jako przykład takiego sztucznego kreowania popytu podali współczesne aparaty fotograficzne oraz planowanie usterek produktów w celu generowania dodatkowego popytu na całe produkty lub części zamienne (szerzej: Poskrobko, Zielińska 2015, s. 281-282).

Zależności między konsumpcją a innowacjami analizowała A. Gardocka-Jałowiec. W publikacji pt.: Zmiany w konsumpcji a kreowanie innowacji wskazała ona na ewolucję podejścia do konsumpcji jako procesu kreowania innowacji. Zgodnie z tym stanowiskiem: „konsumpcja wyznacza warunki, w jakich odbywa się i w oparciu o jakie będzie odbywać się proces kreowania innowacji (następować będzie zmiana jego paradygmatu)" (Gardocka-Jałowiec 2015c, s. 62). Potwierdzają to słowa B. Mroza, który skonstatował, iż: „można spodziewać się, że w przyszłości liczba firm, które wprowadzać będą innowacyjne, przyjazne dla konsumentów oferty rynkowe, będzie wzrastać. Co więcej, elastyczne firmy, szybko reagujące na sygnały płynące z rynku, skoncentrowane na konsumentach, ich potrzebach i oczekiwaniach, będą spychać na margines rynku przedsiębiorstwa lekceważące nowe trendy w zachowaniach konsumentów" (Mróz 2013, s. 205).

Jak zauważyła A. Gardocka-Jałowiec, proces kreowania innowacji nie odbywa się w izolacji podmiotowej i czasowej. Innowacje są efektem aktywności podmiotów, w tym: interesariuszy, pracowników organizacji, lecz również konsumentów, użytkowników finalnych (Gardocka-Jałowiec 2015c, s. 62). Istotnym elementem rozważań jest budowa modelu interakcji między popytem indywidualnym a innowacjami. 


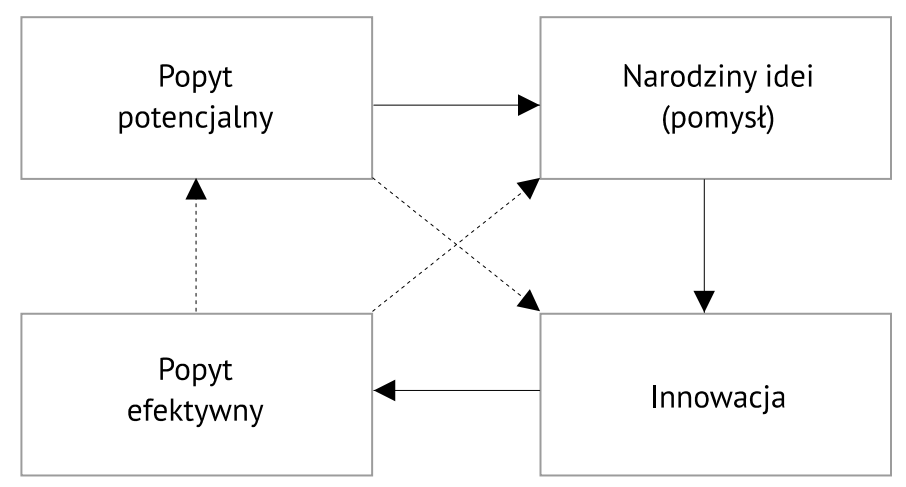

Rysunek 9. Interakcje między popytem indywidualnych podmiotów konsumpcji a innowacjami

Źródło: Gardocka-Jałowiec 2015c, s. 79.

Celem zaprezentowanego modelu jest usankcjonowanie roli konsumenta $\mathrm{w}$ procesie kreowania innowacji. Zgodnie z nim, w przedsiębiorstwach aktywnych innowacyjnie konsumenci nie powinni być postrzegani jedynie jako odbiorcy dóbr, a nawet jako testujący produkty. Rola konsumenta w organizacji zorientowanej na innowacje wykracza poza przekształcanie popytu potencjalnego w popyt efektywny. Konsumenci powinni być również postrzegani jako współkreatorzy innowacji, co oznacza przekształcanie oczekiwań w akceptowane rezultaty w postaci innowacyjnych produktów (Gardocka-Jałowiec 2015c, s. 78-79).

Wobec powyższego, przedsiębiorstwa stoją przed wyzwaniem wpływania na szybką adaptację nowych produktów wśród konsumentów. Jej konieczność wiąże się ze skracaniem cykli życia produktów na rynku. B. Mróz zauważył, że w pierwszej połowie XX wieku średni cykl życia większości wyrobów konsumpcyjnych przekraczał 20 lat. Do lat sześćdziesiątych XX wieku został skrócony do około 5 lat. W latach osiemdziesiątych nie przekraczał już zazwyczaj 2 lat. W ostatnim zaś czasie japońskie korporacje propagują model zgodny z formułą 4-2-2-4, obejmujący koncepcję rocznego cyklu życia produktu (4 miesiące na pomysł i zaprojektowanie, 2 miesiące na agresywną kampanię reklamową, 2 miesiące intensywnej sprzedaży, 4 miesiące związane z fazą schyłkową) (Mróz 2013, s. 58). Kwestia ta jest podkreślana w analizie współczesnych zachowań konsumentów. Z. Bauman pisał, że: „rynek konsumpcyjny oferuje produkty przeznaczone do natychmiastowego, najlepiej jednorazowego użytku, łatwo usuwalne i łatwo zastępowalne" (Bauman 2004, s. 184). Tym samym przedsiębiorstwa wdrażające innowacje, są zmuszone do koncentracji na intensyfikowaniu zainteresowań konsumentów $\mathrm{w}$ fazach wprowadzania nowego produktu na rynek. 
W związku z tym, kluczowe staje się postrzeganie konsumenta jako zasobu organizacji (Bylok 2015, s. 56). Wdrażanie takiej koncepcji powinno odbywać się z uwzględnieniem dwóch kierunków działań:

- po pierwsze, gromadzenie, przetwarzanie i wykorzystywanie szeroko rozumianej informacji o rynku odbiorców, zwłaszcza oczekiwaniach i potrzebach, a także prognozowanych przyszłych kierunkach zmian zachowań nabywców (w postaci trendów zachowań konsumentów);

- po drugie, angażowanie konsumentów w procesy produkcyjne (głównie projektowania i doskonalenia produktów), traktowanie ich kreatywności i twórczości jako szansy na lepsze zaspokajanie potrzeb rynkowych.

Pierwszym ze wskazanych obszarów jest monitorowanie zachowań oraz zachodzących w ich obszarze zmian oraz czynników, które mogą w przyszłości wpływać na zmiany zachowań konsumentów. Jak zauważył B. Mróz: „W przedsiębiorstwach przyszłości wiedza o konsumentach musi zostać pogłębiona i rozszerzona o nowe wymiary, lekceważone lub pomijane w tradycyjnych badaniach marketingowych, zbyt często wykorzystujących płytki behawioryzm i ograniczających się do badania zwyczajów, zachowań konsumentów i reakcji na już istniejące produkty, natomiast w zbyt małym stopniu uwzględniających konsumenckie systemy wartości, postawy, emocje, oczekiwania i antycypujących ich przemiany" (Mróz 2013, s. 186). Informacje od konsumentów mogą stać się - i zapewne staną się - istotnym wymiarem przewagi konkurencyjnej przedsiębiorstw. W celu wykorzystania tego potencjalnego źródła przewagi konkurencyjnej, przedsiębiorstwa muszą jednak zmienić sposób postrzegania rynku z biernych odbiorców produktów i kampanii reklamowych aktywnych uczestników procesu kreowania oferty rynkowej.

Przedsiębiorstwa monitorujące zachowania konsumentów są skoncentrowane na rynku odbiorców, w przeciwieństwie do tradycyjnej orientacji na produktach. Dążą do budowania relacji z konsumentami, natomiast wartość dodaną tworzą nie tylko na bazie produktów, lecz również na bazie usług. Zazwyczaj stosują zindywidualizowane rozwiązania, oparte na relacjach długookresowych, koncentrują się na stałych klientach, nie zaś na pozyskiwaniu nowych. W konsekwencji to właśnie te przedsiębiorstwa przejawiają postawę innowacyjną (Fisk 2009, s. 89).

A. Gardocka-Jałowiec słusznie zauważyła, że informacje o zachowaniach konsumentów są istotne dla przedsiębiorstwa w dwóch wymiarach:

- $\quad$ stanowią bezpośrednie źródło informacji o skuteczności przekształcania popytu potencjalnego w popyt efektywny;

- $\quad$ pośrednio określają możliwości kreowania innowacji oraz strukturę jej komponentów (Gardocka-Jałowiec 2015c, s. 82). 
Nieoczekiwane zadanie w postaci badania i prognozowania zmian zachowań konsumentów okazuje się trudne. B. Mróz wskazał na piętnaście podstawowych źródeł wiedzy o konsumentach. W prezentowanych rozważaniach przedstawiono charakterystykę oraz ocenę przydatności pod kątem kreowania innowacji tych z nich, które, zdaniem autorek, mają największe znaczenie w procesie kreowania innowacji (tabela 5.).

Tabela 5. Podstawowe źródła wiedzy o konsumentach w procesie kreowania innowacji

\begin{tabular}{|c|c|c|c|c|}
\hline Źródło & $\begin{array}{l}\text { Charakter } \\
\text { danych }\end{array}$ & \multicolumn{2}{|c|}{$\begin{array}{l}\text { Funkcje w procesie } \\
\text { kreowania innowacji }\end{array}$} & $\begin{array}{c}\text { Bariery } \\
\text { wykorzystania } \\
\text { w procesie } \\
\text { kreowania innowacji }\end{array}$ \\
\hline $\begin{array}{l}\text { Spisy } \\
\text { powszechne }\end{array}$ & $\begin{array}{l}\text { - zlecane przez } \\
\text { sektor publiczny } \\
\text { - obejmują dane } \\
\text { ilościowe } \\
\text { - prezentują obraz } \\
\text { statystycznego } \\
\text { obywatela }\end{array}$ & \multicolumn{2}{|c|}{$\begin{array}{l}\text { - stanowią tło oceny wyników } \\
\text { badań realizowanych za pomocą } \\
\text { innych metod } \\
\text { - obrazują zmienne socjodemo- } \\
\text { graficzne konsumentów } \\
\text { - powtarzalność badań pozwala } \\
\text { na ocenę dynamiki zjawisk }\end{array}$} & $\begin{array}{l}\text { - standardowy zakres } \\
\text { danych często nie jest } \\
\text { wystarczający na } \\
\text { potrzeby przedsię- } \\
\text { biorstw } \\
\text { - ograniczenia } \\
\text { w zakresie obserwacji } \\
\text { trendów wzrostowych } \\
\text { - ograniczona możli- } \\
\text { wość prognozowania } \\
\text { przyszłych zachowań }\end{array}$ \\
\hline $\begin{array}{l}\text { Badania } \\
\text { ankietowe }\end{array}$ & $\begin{array}{l}\text { - oparte na roz- } \\
\text { prowadzaniu kwe- } \\
\text { stionariuszy ankiety } \\
\text { w możliwie dużej } \\
\text { grupie odbiorców } \\
\text { - ich celem jest } \\
\text { empiryczna wery- } \\
\text { fikacja formułowa- } \\
\text { nych hipotez } \\
\text { - często kończą się } \\
\text { analizą statystyczną }\end{array}$ & \multicolumn{2}{|c|}{$\begin{array}{l}\text { - konkretyzacja przedmiotu badań } \\
\text { - swoboda kształtowania } \\
\text { warunków realizacji badania } \\
\text { oraz doboru próby } \\
\text { - możliwość rozpoznania przy- } \\
\text { czyn analizowanych zjawisk } \\
\text { - możliwość uzyskania danych do } \\
\text { analizy ex-ante } \\
\text { - obejmują dane jakościowe }\end{array}$} & $\begin{array}{l}\text { - niska zwrotność } \\
\text { ankiet, problemy } \\
\text { z zachowaniem } \\
\text { reprezentatywności } \\
\text { próby badawczej } \\
\text { - subiektywność odpo- } \\
\text { wiedzi respondentów } \\
\text { oraz ryzyko niezrozu- } \\
\text { mienia pytań } \\
\text { ankietowych } \\
\text { - ograniczony zakres } \\
\text { wnioskowania } \\
\text { o dynamice zjawisk }\end{array}$ \\
\hline $\begin{array}{l}\text { Panele } \\
\text { konsumenckie }\end{array}$ & $\begin{array}{l}\text { - badanie stałej } \\
\text { grupy konsumen- } \\
\text { tów w celu obser- } \\
\text { wacji ewolucji ich } \\
\text { postaw }\end{array}$ & \multirow{2}{*}{$\begin{array}{l}\text { - szybkie } \\
\text { i efektywne } \\
\text { źródło da- } \\
\text { nych } \\
\text { - możliwość } \\
\text { poznania } \\
\text { subiektyw- } \\
\text { nych opinii } \\
\text { konsumen- } \\
\text { tów }\end{array}$} & $\begin{array}{l}\text { - analiza dyna- } \\
\text { miki zjawisk } \\
\text { w ujęciu jako- } \\
\text { ściowym }\end{array}$ & \multirow{2}{*}{$\begin{array}{l}\text { - brak reprezentatyw- } \\
\text { ności prób } \\
\text { badawczych } \\
\text { - praktyczny brak } \\
\text { możliwości wniosko- } \\
\text { wania o występowa- } \\
\text { niu zjawisk w całej } \\
\text { populacji konsumen- } \\
\text { tów }\end{array}$} \\
\hline $\begin{array}{l}\text { Grupy } \\
\text { fokusowe }\end{array}$ & $\begin{array}{l}\text { - dyskusje na celowo } \\
\text { dobrany temat } \\
\text { z niewielkimi gru- } \\
\text { pami konsumentów }\end{array}$ & & $\begin{array}{l}\text { - generowanie } \\
\text { pomysłów na } \\
\text { nowe produkty } \\
\text { - możliwość } \\
\text { weryfikacji }\end{array}$ & \\
\hline
\end{tabular}




\begin{tabular}{|c|c|c|c|}
\hline \multirow[t]{2}{*}{ Źródło } & \multirow[t]{2}{*}{$\begin{array}{l}\text { Charakter } \\
\text { danych }\end{array}$} & $\begin{array}{l}\text { Funkcje w procesie } \\
\text { kreowania innowacji }\end{array}$ & \multirow[t]{2}{*}{$\begin{array}{c}\text { Bariery } \\
\text { wykorzystania } \\
\text { w procesie } \\
\text { kreowania innowacji }\end{array}$} \\
\hline & & $\begin{array}{l}\text { strategii inno- } \\
\text { wacyjnej } \\
\text { przedsiębior- } \\
\text { stwa }\end{array}$ & \\
\hline $\begin{array}{l}\text { Monitoring } \\
\text { nowych } \\
\text { trendów w } \\
\text { zachowaniach } \\
\text { konsumenc- } \\
\text { kich (tzw. cool } \\
\text { hunting) }\end{array}$ & $\begin{array}{l}\text { - identyfikacja tren- } \\
\text { dów przez sieć spe- } \\
\text { cjalistów (socjolo- } \\
\text { gów trendów) } \\
\text { - analiza zachowań } \\
\text { konsumentów opi- } \\
\text { niotwórczych } \\
\text { (trendsetterów) }\end{array}$ & $\begin{array}{l}\text { - wczesna identyfikacja zmian } \\
\text { w zachowaniach konsumentów } \\
\text { - szansa na wykreowanie innowa- } \\
\text { cji odpowiadającej aktualnym } \\
\text { potrzebom konsumentów przed } \\
\text { działaniami konkurentów }\end{array}$ & $\begin{array}{l}\text { - ryzyko błędnych } \\
\text { prognoz, w wyniku } \\
\text { dynamicznych zmian } \\
\text { w trendach zachowań } \\
\text { konsumentów }\end{array}$ \\
\hline $\begin{array}{l}\text { Analiza skarg } \\
\text { i zażaleń }\end{array}$ & $\begin{array}{l}\text { - zbiorcza rejestracja } \\
\text { i interpretacja skarg } \\
\text { konsumenckich } \\
\text { - identyfikacja } \\
\text { obszarów dosko- } \\
\text { nalenia produktów } \\
\text { na bazie negatyw- } \\
\text { nych opinii } \\
\text { konsumentów }\end{array}$ & $\begin{array}{l}\text { - identyfikacja obszarów } \\
\text { doskonalenia produktów } \\
\text { - wysoka przydatność w kreowa- } \\
\text { niu innowacji organizacyjnych }\end{array}$ & $\begin{array}{l}\text { - ograniczony zakres } \\
\text { wnioskowania } \\
\text { - niska przydatność } \\
\text { w kreowaniu inno- } \\
\text { wacji produktowych, } \\
\text { zwłaszcza o charak- } \\
\text { terze pionierskim } \\
\text { - wysoka zależność } \\
\text { jakości danych od } \\
\text { profilu konsumentów }\end{array}$ \\
\hline $\begin{array}{l}\text { Skanowanie } \\
\text { mózgu (neuro- } \\
\text { obrazowanie, } \\
\text { mindmapping) }\end{array}$ & $\begin{array}{l}\text { - wykorzystanie } \\
\text { funkcjonalnego } \\
\text { rezonansu magne- } \\
\text { tycznego } \\
\text { w celu monitoro- } \\
\text { wania reakcji neu- } \\
\text { rofizjologicznej } \\
\text { mózgu }\end{array}$ & $\begin{array}{l}\text { - możliwość badania podświado- } \\
\text { mej reakcji na określone bodźce } \\
\text { - możliwość weryfikacji innowacji } \\
\text { przed jej wprowadzeniem } \\
\text { - wykorzystanie głównie } \\
\text { w kreowaniu innowacji } \\
\text { marketingowych } \\
\text { - wspomaganie wyboru konkret- } \\
\text { nych cech nowych produktów } \\
\text { - wiarygodność danych }\end{array}$ & $\begin{array}{l}\text { - wysokie koszty } \\
\text { - ograniczone możliwo- } \\
\text { ści wykorzystania } \\
\text { (zwłaszcza w pierw- } \\
\text { szych fazach procesu } \\
\text { kreowania innowacji) }\end{array}$ \\
\hline $\begin{array}{l}\text { Wiedza } \\
\text { personelu }\end{array}$ & $\begin{array}{l}\text { - nieformalna, nieu- } \\
\text { porządkowana, } \\
\text { a często także } \\
\text { nieujawniona } \\
\text { wiedza sprzedaw- } \\
\text { ców i innych osób } \\
\text { bezpośrednio } \\
\text { wchodzących } \\
\text { w relacje z konsu- } \\
\text { mentami }\end{array}$ & $\begin{array}{l}\text { - identyfikacja obszarów } \\
\text { doskonalenia } \\
\text { - możliwość włączenia tej grupy } \\
\text { pracowników do zespołów } \\
\text { opracowujących nowe produkty } \\
\text { i usługi }\end{array}$ & $\begin{array}{l}\text { • konieczność stworze- } \\
\text { nia odpowiedniej } \\
\text { kultury innowacji, } \\
\text { dzielenia się wiedzą, } \\
\text { jak również nastawie- } \\
\text { nia na ciągłe dosko- } \\
\text { nalenie organizacji } \\
\text { (wdrażanie zasad } \\
\text { organizacji opartej } \\
\text { na wiedzy) } \\
\text { - wysoka fluktuacja } \\
\text { pracowników }\end{array}$ \\
\hline
\end{tabular}

Źródło: opracowanie własne z wykorzystaniem klasyfikacji i charakterystyki technik na podstawie: Mróz 2013, s. 232-236. 
Pierwszym ze wskazanych źródeł danych są spisy powszechne. Są one wykonywane przez określone agencje badawcze na zlecenie podmiotów sektora publicznego. Ich zakres najczęściej jest ograniczony do danych ilościowych, na bazie których możliwe jest stworzenie obrazu przeciętnego obywatela w danej chwili. Istotną zaletą tej metody jest powtarzalność, co pozwala na analizę nie tylko stanu obecnego, lecz również dynamiki zachodzących zmian. Jednak ze względu na standardowy zakres danych zazwyczaj nie są one dostatecznym źródłem informacji dla poszczególnych przedsiębiorstw, ale stanowią łło oceny wyników uzyskiwanych z innych typów badań. Co więcej, uśrednienie wyników uniemożliwia obserwację trendów, które mogą dotyczyć niewielkiej grupy konsumentów i posiadać charakter wzrostowy, tym samym nie pozwala na obserwację prognozowania zmian ważnych dla działalności innowacyjnej. Natomiast diagnozowanie tych zmian w początkowych etapach ich występowania jest niezmiennie istotne w kreowaniu innowacji. Spisy powszechne mogą być wykorzystane do zobrazowania segmentu docelowego przedsiębiorstwa, tworząc podstawę doboru próby w innych metodach badawczych.

Kolejne wyodrębnione źródła danych stanowią badania ankietowe. Opierają się one na analizie opinii i deklarowanych preferencji konsumentów wyrażanych za pomocą standaryzowanych kwestionariuszy ankiet. Badania tego typu dążą do zachowania reprezentatywności, co powoduje, że wyniki najczęściej mogą być uogólniane na całą badaną populację. Kwestionariusze ankiet mogą być dobrowolnie formułowane ze względu na zakres informacji, jakie przedsiębiorstwo chce uzyskać. Tym samym zakres wiedzy uzyskanej dzięki badaniom ankietowym w pełni odpowiada aktualnym potrzebom przedsiębiorstw. W szczególności dają one szansę na wnikliwą analizę danych pochodzących ze spisów powszechnych oraz rozpoznanie przyczyn obserwowanych w nich zmian. Zasadniczą przewagą z racji kreowania innowacji jest możliwość analizy zmiennych jakościowych, które umozliwiają ocenę kierunku zmian zachowań konsumentów oraz poziomu ich optymizmu i planów inwestycyjnych. Główną barierą wykorzystania badań ankietowych w przedsiębiorstwach jest niska zwrotność ankiet. Co więcej, istnieje ryzyko subiektywizmu ocen deklarowanych przez konsumentów. Forma ankietowa ogranicza sposobność kontroli poziomu zrozumienia pytań przez badanych, nie daje możliwości zadawania dodatkowych pytań wyjaśniających udzielane odpowiedzi. Ponadto, badania ankietowe w większości nie pozwalają na formułowanie wniosków w zakresie dynamiki zjawisk, z uwagi na ograniczone powtórzenie badań na tym samym materiale badawczym. 
Z punktu widzenia procesu kreowania innowacji są również istotne dane zebrane przez organizację paneli konsumenckich i grup fokusowych. Panele konsumenckie stanowią cykliczne badania określonej grupy konsumentów w celu analizy ich postaw i zachowań. Z kolei, grupy fokusowe są organizowane doraźnie. Obejmują analizę swobodnych wypowiedzi celowo dobranych grup konsumentów, często z wykorzystaniem lustra weneckiego. Ich zaletą jest szybkość zbierania informacji oraz stosunkowo niskie koszty. Badania te dotyczą danych jakościowych i pozwalają na analizę poglądów i opinii respondentów. Badania panelowe umożliwiają analizę zmian jakościowych w ujęciu dynamicznym. Łączą więc cechy spisów powszechnych $\mathrm{z}$ badaniem ankietowym. Natomiast badania fokusowe mogą stanowić istotne źródło inspiracji w procesie kreowania nowych produktów. Dają możliwość weryfikacji strategii innowacyjnej przedsiębiorstwa. Jednak słabością obu rodzajów badań jest niereprezentatywność prób badawczych. To zaś rodzi ryzyko nieodzwierciedlania poglądów ogółu konsumentów przez małe grupy. Możliwości wnioskowania na podstawie tego typu badań są więc ograniczone, a uzyskane wyniki wiążą się z dużym poziomem subiektywizmu.

Szczególnie istotne w procesie kreowania innowacji wydają się badania nowych trendów zachowań konsumentów. Prowadzone są one przez specjalistów, zwanych socjologami trendów. Głównie dotyczą analizy zachowań grup docelowych i konsumentów-trendsetterów, pełniących funkcję opiniotwórczą oraz kreujących wzory konsumpcji podlegające naśladownictwu. Analiza trendów zachowań konsumentów daje sposobność prognozowania i wczesnej identyfikacji przyszłych preferencji i kierunku rozwoju potrzeb ogółu konsumentów. Tym samym jest ona szansą na wykreowanie nowych produktów odpowiadających zapotrzebowaniu rynku, a w następstwie wyprzedzenie konkurencji, choć towarzyszy im pewne ryzyko wynikające z wrażliwości trendów na zmiany makrootoczenia gospodarczego. Zatem istnieje ryzyko nadania polityce innowacyjnej kierunku zgodnego z prognozowanymi trendami, które ulegną szybkiej dezaktualizacji.

Źródłem informacji w procesie kreowania innowacji - zwłaszcza dzięki doskonaleniu obecnych produktów - może być również analiza skarg i zażaleń konsumentów. Składa się na nią zbiorcza analiza, interpretacja, a w konsekwencji identyfikacja obszarów doskonalenia produktów na podstawie negatywnych opinii konsumentów. Przedsiębiorstwa mogą więc wprowadzać szybkie zmiany w obszarach będących źródłem dyssatysfkacji konsumentów. Jednak należy zwrócić uwagę na szereg ograniczeń związanych z wykorzystaniem tego źródła informacji. Przede wszystkim pozwala ono na formułowanie wniosków jedynie w obszarze wybranych form innowacji. W większej 
mierze służy modyfikacji produktów, ewentualnie tworzeniu innowacji adaptacyjnych czy realizacji innowacyjnych sposobów ich zastosowania, niż kreowaniu pionierskich innowacji. Analiza skarg i zażaleń może być szczególnym źródłem informacji w tworzeniu innowacji organizacyjnych, w tym związanych z procesem obsługi klienta. Zakres uzyskanych informacji jest uzależniony ddo segmentu docelowego i profilu konsumenta, w tym postaw przejawianych wobec komunikacji bezpośredniej z przedsiębiorstwami, stopnia wykorzystania Internetu (ułatwiającego proces składania skarg) jako środka komunikacji i wieku. Z powyższych względów, analiza skarg i zażaleń może, co prawda, stanowić uzupełnienie stanu wiedzy na temat konsumentów, lecz nie powinna być podstawowym jej źródłem w przedsiębiorstwie.

Badania, bazujące na neuroobrazowaniu, pomiarze aktywności mózgu i określaniu wpływu na nią poszczególnych impulsów, także mogą przynosić wiedzę o konsumentach. W tym celu najczęściej wykorzystuje się techniki tomografii komputerowej, tomografii metodą rezonansu magnetycznego i elektroencefalografii (szerzej: Jaśkowski 2009, s. 42 i nast.). Badania te są przydatne w procesie testowania innowacji, pozwalają bowiem na odczytanie nieuświadomionej reakcji konsumentów na produkty i przesyłane komunikaty. Konsumenci-innowatorzy są zazwyczaj aktywni w poszukiwaniu innowacji. Ważne jest więc dostarczenie takiej informacji, która będzie stanowiła pozytywne i silne bodźce w procesach decyzyjnych. Z tego względu badania te są szczególnie przydatne w kreowaniu innowacji marketingowych. Co więcej, mogą służyć weryfikacji cech innowacyjnego produktu przed jego wprowadzeniem na rynek, ocenie poszczególnych jego cech oraz wyboru określonego wariantu cechy produktu spośród rozważanych (kolor, kształt, pojemność, materiał wykonania). Jednak, możliwość wykorzystania, głównie na etapie weryfikacji, stanowi ograniczenie tej metody badawczej. Istotną wadą jest również wysoki koszt badań. Jednocześnie należy dodać, iż badania neuroobrazowania są nieusankcjonowane w naukach ekonomicznych. Jedynym obszarem ich dynamicznego wykorzystania jest neuromarketing. W ostatnim czasie zainteresowanie wykorzystaniem skanowania mózgu wzrasta w ramach neuroekonomii i neurofinansów.

Ostatnim ze wskazanych źródeł informacji o konsumentach, przydatnych w procesie kreowania innowacji, jest wiedza pracowników przedsiębiorstwa. Często nie docenia się jej w procesie kreowania nowych produktów, co jest związane z: jej nieformalnym charakterem, niskim uporządkowaniem, a często nawet jej nieuświadomieniem przez pracowników. Ci jednak - jako osoby wchodzące w bezpośrednie relacje z konsumentami - są w stanie identyfikować obszary szczególnej satysfakcji oraz niezadowolenia 
konsumentów. Ich wiedza może więc być źródłem informacji o obszarach doskonalenia produktów. Ograniczenia dotyczące jej wykorzystania są podobne do analizy skarg i zażaleń konsumentów. Wiedza ta ma bowiem ograniczoną przydatność w procesie kreowania nowych produktów, zwłaszcza pionierskich. W celu ujawnienia i wykorzystania wiedzy pracowników niezbędne jest jednak budowanie odpowiedniej kultury organizacyjnej, opartej na dzieleniu się informacjami oraz dążeniu - poprzez wspólne działania - do ciągłego doskonalenia. To zaś wymusza konieczność zrozumienia roli zespołu pracowniczego i traktowania wiedzy organizacyjnej w kategoriach zasobu. Obszar ten jest analizowany w zakresie koncepcji organizacji opartej na wiedzy.

Obok omówionego, pierwszego wymiaru wpływu konsumentów na realizowaną działalność innowacyjną (dzięki wykorzystaniu szeroko rozumianej informacji o zachowaniach konsumentów), można wskazać na drugi wymiar tego wpływu. Jest nim angażowanie konsumentów w procesy produkcyjne obejmujące głównie zapewnienie im możliwości udziału w tworzeniu wizji oraz projektowaniu wyrobów i usług.

Szansę na zastosowanie potencjału konsumentów stanowi ich włączenie w proces kreowania innowacji. Jak wskazali T.J. Balsano i inni, konsumenci chcą być postrzegani jako kreujący innowacje, co pozwala na przekształcanie ich oczekiwań w rezultaty (Balsano i in. 2008, s. 22). Zmiana mentalności przedsiębiorców umożliwia nadanie konsumentom znaczenia jako potencjału organizacji. Z tego względu przedsiębiorstwa coraz częściej zachęcają konsumentów do dzielenia się pomysłami i wiedzą. Konsumenci przestają więc być biernymi odbiorcami, a stają się aktywnymi uczestnikami procesów produkcyjnych.

Obecnie na rynku rośnie liczba przedsiębiorstw, które stwarzają warunki udziału konsumentów w procesie projektowania produktów. Przykładowo, firma Streif za pomocą strony internetowej umożliwia udział konsumentów w projektowaniu domu za pomocą odpowiedniego konfiguratora. Podobnie, producent klocków LEGO oferuje usługę LEGO Digital Designer. Dzięki niej konsumenci mogą projektować elementy i zestawy budowli, przy czym najlepsze pomysły są produkowane masowo i zamieszczane w katalogach firmy (Bylok 2015, s. 56).

Zaangażowanie konsumentów w proces kreowania innowacji poprzez bezpośrednie umożliwienie udziału w projektowaniu produktów sprzyja osiągnięciu korzyści w postaci lepszego dostosowania produktów do potrzeb odbiorców. Nowe, zgłaszane przez konsumentów idee są istotnym impulsem do zmian produkcyjnych w przedsiębiorstwach. To natomiast skutkuje wyższą akceptację nowości w momencie wprowadzania na rynek (Bylok 2015, 
s. 56). Konsumenci mogą być zarówno źródłem całkowicie nowatorskich pomysłów, jak i brać udział w doskonaleniu obecnych już na rynku produktów.

J. Fuller i inni jako obiecujące źródło innowacji wskazali tzw. grupy konsumenckie online. Są one związane z samoistnym lub stymulowanym z inicjatywy przedsiębiorstwa kształtowaniem wirtualnych grup interesu, opartych na wymianie wiedzy dotyczącej konkretnego produktu, w celu omówienia możliwości kreowania nowych produktów i pomysłów na ulepszanie obecnych dóbr rynkowych. Doskonałym przykładem wdrażania idei jest tworzenie oprogramowania typu open source (Fuller i in. 2006, s. 56-57).

Szczególny rodzaj zaangażowania konsumentów w proces projektowania produktów stanowi idea tzw. crowdsourcingu. Oznacza ona: „integrację szerokiej grupy ludzi z zewnątrz z daną organizacją lub osobą w celu działań twórczych" (Kościelniak, Brendzel-Skowera 2014, s. 146-147). Wiąże się więc z traktowaniem „tłumu" (ang. crowd) jako zasobu organizacji. W zakresie działań crowdsourcingowych jest możliwe wyodrębnienie kilku płaszczyzn współpracy $^{5}$, jednak ze względu na kreowanie innowacji istotne znaczenie ma tzw. działalność co-creation. Polega ona na współtworzeniu i wspólnym wykonywaniu pracy twórczej przez społeczność. Jego realizacji służy zastosowanie sieci internetowej oraz wykorzystanie jej w procesie kreowania innowacji.

Kreowanie innowacji wśród konsumentów może mieć zarówno charakter zorganizowany, jak i spontaniczny. Jak zauważyli A. Dąbrowska i inni, konsument, wykorzystując innowacje, modyfikuje własny wzór konsumpcji. Tym samym, korzystając z nowych produktów pojawiających się na rynku, tworzy nowe pomysły na ich zastosowanie. Przykładowo: „do przygotowania dań używa innowacyjnych produktów nie według oryginalnych receptur, lecz poszukuje własnych rozwiązań, które są kombinacją starych i nowych, oryginalnych przepisów" (Dąbrowska i in. 2015, s. 117). W ten sposób konsumenci tworzą własne, nowe innowacje w konsumpcji. Te zaś mogą podlegać komercjalizacji przez przedsiębiorstwa, które dostrzegają rolę konsumentów w ich kreowaniu. Stąd można powiedzieć, że cykl kreowania innowacji jest okrężny. Z jednej strony, innowacje zmieniają preferencje i oczekiwania konsumentów, a w konsekwencji ich zachowania rynkowe, z drugiej zachowania konsumentów są źródłem innowacyjnych pomysłów, które mogą być wdrożone na rynek.

\footnotetext{
${ }^{5}$ W tym: crowdfunding (wspólne finansowanie projektów społecznościowych), co-creation, microtasking (wykonywanie przez społeczność drobnych zadań w ramach projektów), ARTsourcing (forma kierowana do specjalistów od designu), za: Kościelniak, BrendzelSkowera 2014, s. 146-147.
} 


\subsection{Trendy zachowań konsumentów w kreowaniu innowacji}

Przejawem innowacyjności w zachowaniach współczesnych konsumentów na rynku są tzw. nowe trendy konsumpcyjne (Zalega 2015, s. 18). F. Shaw stwierdził, że w polityce przedsiębiorstwa i jego strategii analiza tych trendów zajmuje istotne miejsce. Tworzą one bowiem reguły funkcjonowania organizacji (Shaw 2009) ukierunkowanych w stronę kreowania nowych produktów, odpowiadających rodzącym się potrzebom konsumentów.

Analiza trendów zachowań konsumentów pokazuje, w jaki sposób zmieniają się zachowania nabywców. Co za tym idzie, na jej podstawie jest możliwe podejmowanie działań dostosowujących ofertę do potrzeb rynku odbiorców. Z jednej strony zrozumienie kierunków zmian zachowań konsumentów pozwala na kształtowanie strategii nowych produktów. Z drugiej rozwój pewnych trendów może sprzyjać innowacyjności konsumentów, tym samym tworząc odpowiednie warunki do adaptacji innowacji w gospodarce. Ich obserwacja może służyć nie tylko kreowaniu nowych wyrobów, ale i prognozowaniu szybkości adaptacji innowacji.

Analiza trendów zachowań konsumentów jest szczególnie istotna z perspektywy organizacji uczącej się i organizacji opartej na wiedzy. Stanowią one tę grupę przedsiębiorstw, które postrzegają wiedzę jako jeden z najważniejszych zasobów cechujący się zdolnością kumulacji i rozwoju (Poskrobko 2011, s. 41). Wiedza organizacji obejmuje m.in. informacje o cechach rynku odbiorców oraz prognozowanych kierunkach ich zmian. Jak stwierdził R. Romanowski: „przedsiębiorstwa oparte na wiedzy powinny umieć zamieniać wiedzę o istniejących trendach konsumenckich na produkty, komercjalizując wyniki dostępnych badań" (Romanowski 2013, s. 24). W związku z tym, w obliczu rosnącego zainteresowania traktowaniem wiedzy jako ważnego zasobu organizacji, przedsiębiorstwa powinny posiadać zdolność do wykorzystania wiedzy o trendach wśród konsumentów.

Pojęcie trendu można interpretować w sensie ogólnym, w odniesieniu do nauk społecznych i w ujęciu węższym, w odniesieniu do teorii zachowań konsumentów. H. Vejlgaard - autor publikacji Anatomia trendu - zaproponował, by przez to pojęcie rozumieć: pewnego rodzaju przewidywanie, antycypację czegoś, co się wydarzy i zostanie zaakceptowane przez statystycznego człowieka. Stąd pojęcie to odnosi się do pierwszych symptomów zmiany, a więc do: „zmiany, która rozpoczyna się od kreatorów, tendsetterów, a następnie przenosi na szersze wody mainstreamu" (Vejlgaard 2008, s. 26). W ten sposób na znaczeniu zyskuje ujęcie trendu jako istniejącej w danym momencie prawidłowości rozwoju $\mathrm{w}$ jakiejś dziedzinie. W naukach społecznych trendem nazywa się: „zmiany zachodzące w czasie w zjawisku 
społecznym lub rynkowym, których kierunek daje się mierzyć za pomocą określonych wskaźników, skal pomiarowych, indeksów itp." (Mróz 2013, s. 115-116). Na gruncie zachowań konsumentów trendem będzie więc pewien kierunek zmian w zachowaniach konsumentów, ich stylu życia oraz podejmowanych decyzjach zakupowych. Jest to zatem pewna tendencja rozwojowa, powstająca w: wyniku oddziaływania szeregu czynników na konsumentów ${ }^{6}$, która najprawdopodobniej będzie rozszerzać się na szersze grupy odbiorców.

H. Vejlgaard naukę o trendach nazwał socjologią trendów. Przez pojęcie to rozumiał naukę badającą procesy powstawania i upowszechniania trendów. Z kolei, osoby zajmujące się tą działalnością określił mianem socjologów trendów. Ich praca polega na obserwacji i prognozowaniu zmian w trendach w różnych sferach życia (Vejlgaard 2008, s. 26).

Zdaniem H. Vejlgaarda, pojęcie trendu wymaga dostrzeżenia zmiany w czasie, która może być rozpatrywana z perspektywy psychologicznej, ekonomicznej czy społecznej, może rozwijać się zarówno w krótkim, jak i długim czasie. Co więcej, trendy mogą mieć charakter regionalny lub globalny (Vejlgaard 2008, s. 9-10). Trendy zachowań konsumentów - jak zauważył B. Mróz - zazwyczaj wschodzą i rozwijają się przez pewien okres. Mogą dotyczyć wielu sfer życia konsumenta, ostatecznie wpływających na jego preferencje w zakresie nabywanych produktów (Mróz 2013, s. 117). Z tego względu, celem rozpoznania trendów zachowań konsumentów, konieczna jest nie tylko obserwacja ich obecnych decyzji, lecz również otoczenia, w tym: ekonomicznego, społecznego, technologicznego, które warunkują kierunki zmian. Wymaga to holistycznego podejścia do zachowań ekonomicznych, pozwalającego na umiejscowienie ich w ogólnie rozumianym makrootoczeniu.

H. Vejlgaard, analizując anatomię powstawania trendów, wskazał warunki, które muszą zaistnieć, aby trend pojawił się, a następnie ugruntował. Dotyczą one:

- $\quad$ podatności grup społecznych na trend;

- $\quad$ akceptacji trendu przez odpowiednio dużą liczbę osób;

- $\quad$ zainteresowania mediów danym trendem.

Przede wszystkim trend musi trafić do określonych grup społecznych. Warunkiem rozpowszechnienia jest dostateczna liczba osób, która chce zaakceptować dany trend (trendsetters). Ta zaś będzie wpływać na rozpowszechnienie trendu wśród naśladowców (trend followers). W opinii autora,

\footnotetext{
${ }^{6} \mathrm{~W}$ literaturze jest również stosowane pojęcie megatrendu, oznaczającego taki trend, który obejmuje długie oddziaływanie, wykraczające poza jedną dziedzinę życia i jeden rejon geograficzny (Kucharska 2014, s. 220).
} 
ważne jest również, aby trend był przedmiotem zainteresowania mediów, co nada dynamikę jego rozwojowi i pozwoli na dotarcie do szerszego grona odbiorców (Vejlgaard 2008, s. 163-164).

W odniesieniu do innowacji trendsetterzy stanowią grupę konsumentów innowatorów. Są to osoby najwcześniej nabywające innowacyjne produkty. Z tego względu, aby zaistniał trend w zakresie innowacyjnych produktów, a zainteresowanie nim ekspandowało na szersze grupy odbiorców, ważne jest oddziaływanie na trendsetterów.

Rozpoznawanie i diagnoza nowych trendów zachowań konsumentów nie jest w pełni działalnością intuicyjną. W istocie polega na wykorzystaniu szeregu metod analizy danych ilościowych i jakościowych oraz analizie przyczynowo-skutkowej otoczenia w celu wyodrębnienia czynników kształtujących konsumpcję w przyszłości (Mróz 2013, s. 126). Na tej podstawie są tworzone prognozy trendów, które zakomunikowane interesariuszom mogą pozytywnie wpłynąć na dostosowanie innowacji wprowadzonych na rynek do wymagań odbiorców.

Zmiany zachowań konsumentów, jakie można obserwować od początku XXI wieku, są wielokierunkowe i dynamiczne. Stanowią wypadkową wielu czynników. Cechuje je:

- zmienność,

- współwystępowanie,

- $\quad$ dywergencja (pojawianie się kontrtrendów) (Zalega 2013, s. 4).

Zmienność trendów zachowań konsumentów powoduje trudności z ich prognozowaniem. W obliczu turbulentnych zmian otoczenia gospodarczego zdarza się, że style konsumpcji ewoluują, nieoczekiwanie przybierając inny kierunek niż wskazują prognozy. Co więcej, charakteryzuje je współwystępowanie. Oznacza to, że praktycznie nie jest możliwe wskazanie trendów głównych i pobocznych.

Współczesne trendy zachowań konsumentów w sposób szczególny wyróżnia dywergencja. W obrębie tych samych dziedzin gospodarowania wzajemnie przenikają się przeciwstawne kierunki zachowań konsumentów. F. Van Raaij podkreślił, że cechą nowych form konsumpcji jest właśnie współistnienie elementów przeciwstawnych. Zaznaczył, że przejawia się to dywersyfikacją popytu, a poszukiwanie indywidualnej tożsamości przenika się z konsumpcjonizmem i ujednolicaniem wzorców konsumpcji na świecie (Raaij 2001, s. 342). Zdaniem B. Mroza, koegzystencja krańcowo odmiennych tendencji jest charakterystyczna dla współczesnych społeczeństw konsumpcyjnych (Mróz 2013, s. 48).

Biorąc pod uwagę zarówno znaczenie trendów zachowań konsumentów w działalności przedsiębiorstw, jak i dynamikę ich zmian, warto poddać ana- 
lizie możliwość wykorzystania wiedzy na ich temat na gruncie działalności innowacyjnej.

W tym miejscu zostaną przedstawione dwie koncepcje analizy trendów zachowań konsumentów. Pierwsza z nich w centrum zainteresowania stawia procesy globalizacyjne. Obejmują one kształtowanie wzrastającej sieci powiązań i współzależności krajów i regionów, zarówno w wymiarze gospodarczym, technologicznym, kulturowym, jak i społecznym (Friedman 2006, za: Bocian 2009, s. 159). Globalizacja staje się źródłem dwóch przeciwstawnych, jednak występujących równocześnie, tendencji zachowań konsumentów. W globalnej gospodarce można obserwować w równej mierze zjawisko ujednolicania (homogenizacji), jak i różnicowania (polaryzacji) wzorców zachowań konsumentów (Dąbrowska i in. 2015, s. 19). Z jednej strony następuje unifikacja zachowań konsumenckich w skali globalnej prowadząca do detradycjonalizacji, z drugiej równocześnie postępuje ich różnicowanie (Kiełczewski 2005).

Homogenizacja konsumpcji oznacza upodabnianie się wzorców konsumpcji społeczeństw niezależnie od granic państwowych, które tworzy swoistą kulturę konsumpcji globalnej. Bezpośrednią przyczyną jest oferowanie jednolitych dóbr na globalnym rynku oraz upowszechnianie marek (takich jak: Nike, Coca Cola czy IBM) i produktów globalnych (jak i-Pod czy smartfon), rozpoznawanych i nabywanych na całym świecie. Wynika to z dominacji wielkich korporacji, ujednolicania produkcji oraz tworzenia globalnych systemów dystrybucji (Bylok 2002, s. 74-82). Homogenizacji sprzyja: rozwój sieci internetowych, nieskrępowany przepływ informacji, zacieranie granic państwowych. Obecne rozpowszechnienie mass mediów pozwala na zapoznanie konsumentów z innymi kulturami, stanowi więc propozycję różnych stylów życia. Do umacniania kultury masowej przyczyniają się również migracje i światowy ruch turystyczny (Wildowicz-Giegiel 2009, s. 5).

Homogenizacja konsumpcji w istocie nie jest zjawiskiem negatywnym. Istnienie produktu globalnego znacząco ułatwia konsumentom proces podejmowania decyzji, skraca go i obniża odczuwany poziom ryzyka (MazurekŁopacińska 2003, s. 42). Konsument, kupując globalny produkt, ma pewność, że osiągnie określony poziom zadowolenia. Jak zwróciła uwagę K. Sitkiewicz: „poczucie spokoju zapewnia (...) pewność, że frytki w McDonald'sie są zawsze tej samej długości, że hamburger ma taką samą wielkość, że w centrum handlowym zawsze (o każdej porze dnia i nocy) dostaniemy potrzebne nam produkty" (Sitkiewicz 2009, s. 12).

Wpływ homogenizacji konsumpcji na rozwój innowacji może być dwukierunkowy. Po pierwsze, zaufanie konsumentów przyśpiesza akceptację innowacyjnych produktów oferowanych pod rozpoznawaną marką. Naby- 
wając innowacyjny produkt globalnej marki, konsument odczuwa niższy poziom niepewności związany z zakupem. Z drugiej strony przywiązanie do określonych produktów może stanowić barierę dotyczącą wprowadzania zmian w zachowaniach konsumentów, zmniejszając ich zainteresowanie produktem, który - w fazie wprowadzenia na rynek - nie ma cech produktu globalnego.

Równolegle rozwijającym się trendem zachowań konsumentów jest heterogenizacja, będąca dążeniem do zaakcentowania odmienności oraz kreowania własnej tożsamości, także w obszarze konsumpcji. Jej skutkiem jest narastające zróżnicowanie zachowań konsumpcyjnych (Wildowicz-Giegiel 2009, s. 6-7). Konsument XXI wieku coraz częściej pragnie manifestować swoją indywidualność i niepowtarzalność. Paradoksalnie demokratyzacja i umasowienie konsumpcji wyzwalają dążenie do podkreślania odrębności.

Odpowiedzią przedsiębiorstw na tendencje heterogenizacji konsumpcji jest tzw. kastomeryzacja. Obejmuje ona oferowanie indywidualnym klientom dóbr i usług specjalnie dostosowanych do ich potrzeb dzięki nawiązywaniu więzi z klientem, skracaniu kanałów dystrybucji oraz rezygnacji z produkcji masowej (Tkaczyk, Kołuda 2013, s. 26). Rekompensatą ma być kreowanie postaw lojalnościowych wśród konsumentów.

Obok kastomeryzacji, w literaturze występuje również pojęcie kastomizacji, które bezwzględnie należy odróżnić od pierwszego. Kastomizacja oznacza możliwość produkcji na zamówienia indywidualne. Dzięki Internetowi jest możliwy udział konsumentów w projektowaniu produktów na specjalne zamówienia (Mróz 2013, s. 191). Natomiast kastomeryzacja wiąże się z personalizacją nie tylko oferty produktowej, lecz również działań marketingowych, czyli dostosowanie całości działań organizacyjnych do potrzeb odbiorców. Dotyczy także innowacji marketingowych (Mróz 2013, s. 192) i organizacyjnych.

Zarówno homogenizacja, jak i heterogenizacja wpływają na rozwój trendów zachowań konsumentów, co na przedsiębiorstwach wymusza podjęcie decyzji w zakresie wyboru między ujednolicaniem a różnicowaniem produktów. Ścieranie się dwóch przeciwstawnych tendencji powoduje zainteresowanie kształtowaniem produktów hybrydowych. Obejmuje ono dostosowanie globalnych produktów do potrzeb mieszkańców danego regionu. Przykładem może być zmiana składu produktów McDonald's w krajach o przewadze wyznania islamskiego czy zmiana wielkości naczyń kuchennych przez firmę IKEA na rynku amerykańskim. Z perspektywy konsumenta hybrydyzacja może wyrażać się w akceptowaniu globalnego produktu oraz przystosowaniu go do lokalnych systemów wartości i lokalnych sposobów 
użytkowania (Bywalec, Rudnicki 2002, s. 140-141) lub w dążeniu do nadania mu unikatowych cech, pomimo istnienia globalnego wzorca.

Aby zapewnić konsumentom poczucie indywidualnego zaspokojenia ich potrzeb, część przedsiębiorców decyduje się na produkcję niezliczonej ilości odmian jednego produktu (Ritzer 2005, s. 331), tworząc w ten sposób produkty hybrydowe. Takie zjawisko w literaturze jest nazywane adidasacją. Przykładem może być produkcja wielu modeli obuwia sportowego jednej marki o różnym przeznaczeniu, a mianowicie: buty do biegania, do fitness, do tenisa, w niezliczonej gamie kolorystycznej. W istocie strategia taka nosi znamiona pozornej heterogenizacji, zaspokajającej, co prawda, potrzeby wyróżnienia się konsumentów, jednak ujednolicających ich wzory konsumpcji.

$\mathrm{Na}$ bazie ścierających się tendencji ujednolicania i indywidualizacji konsumpcji kształtuje się szereg trendów zachowań konsumentów. B. Mróz wyodrębnił dziesięć, jego zdaniem, najistotniejszych. Są nimi: mieszanie się płci, trend LOHOS, samoleczenie, trysumer, współpraca konsumencka, demokratyzacja luksusu, technicyzacja, cyfrowa absencja, natychmiastowa gratyfikacja i hiperpersonalizacja (Mróz 2013, s. 126-164). Obok wskazanych, do najważniejszych trendów, które wpływają na zachowania konsumentów i mogą je kształtować w przyszłości - w opinii autorów - można również zaliczyć: juwenalizację, dekonsumpcję, trend wygody i hedonizm konsumencki i kokonizację.

Trend mieszania się płci (ang. gender blending) polega na zacieraniu granic między tradycyjnie postrzeganymi rolami, zachowaniami oraz wzorami konsumpcji kobiety i mężczyzny. Z jednej strony mężczyźni nabierają cech i zachowań kobiecych, bardziej dbają o wygląd, angażują się w prace domowe i opiekę nad dziećmi. Z drugiej strony rośnie asertywność, aktywność zawodowa i samodzielność kobiet (Mróz 2013, s. 134-136). Rozwój tego trendu wpływa na zmiany w kształtowaniu produktów dostarczanych na rynek. Rynek docelowy produktów traktowanych jako typowo męskie rozszerza się o segment kobiecy. Z myślą o kobietach powstają nowe typy: komputerów osobistych, samochodów, telefonów, klubów sportowych, sprzętu do ćwiczeń. Istotnym rynkiem docelowym sektora kosmetycznego stają się także mężczyźni. Mieszanie się płci powoduje wykreowanie nowego typu produktów, określanych jako unisex. Przykładem takich produktów są linie perfum, a nawet ubrań.

Kolejnym, wymienionym przez B. Mroza, trendem zachowań konsumentów jest trend LOHOS (akronimem od ang. lifestyles of health and sustainanility). Obejmuje on nowe podejście do życia i konsumpcji - przeciwne konsumpcjonizmowi - oparte na dbałości o zdrowie i środowisko, a zarazem szukaniu wewnętrznej równowagi (Mróz 2013, s. 136-137), równocześnie 
poprzez dobór nabywanych produktów. Jego konsekwencją rynkową jest większe zainteresowanie produktami ekologicznymi, w tym produktami bez konserwantów, obniżanie ilości spożywanych kalorii. W efekcie na rynku pojawiają się marki specjalizujące się w produkcji ekologicznej żywności. Trend rozszerza się również na inne dziedziny życia. Konsumenci poszukują kosmetyków bez dodatków chemicznych czy ekologicznych proszków do prania, preferują opakowania biodegradowalne bądź samochody hybrydowe. Zachowania takie mogą wynikać z pozytywnej postawy wobec środowiska naturalnego, lecz także mogą być motywowane: dbałością o zdrowie, rozpowszechnianiem nowych stylów życia, modą lub wpływem grup społecznych (Matel 2016, s. 56-58).

Konsumenci, kierujący się filozofią życiową, preferują zrównoważone style życia, oparte na koncepcji slow. Jej podstawową zasadą jest przeciwstawianie się konsumpcjonizmowi, zwłaszcza szybkiemu dążeniu do osiągnięcia gratyfikacji w formie sukcesu materialnego (Kiełczewski, 2012).

$\mathrm{Na}$ gruncie trendu LOHOS rozwija się ekokonsumpcja. Jak pisał $\mathrm{T}$. Zalega, polega ona na celowym dążeniu jednostek do minimalizacji niekorzystnych efektów, wynikających ze spożycia dóbr i usług, oraz zmniejszaniu wytwarzanych odpadów (Zalega 2015, s. 5). Badania prezentowane przez I. Escher i J. Petrykowską (Escher, Petrykowska 2014, s. 32-33) pokazały, że jest to nadal uboczny, choć wzrostowy, trend wśród polskich konsumentów. Wprawdzie 72\% badanych ma styczność z żywnością ekologiczną, jednak zaledwie 5,4\% kupuje ją zawsze, kiedy ma możliwość, zaś 66,6\% - od czasu do czasu. Co więcej, badania wykazały, że ekokonsumpcja ma istotny związek z trendem LOHOS, gdyż 74,1\% badanych, kupujących produkty ekologiczne, motywuje to troską o zdrowie, natomiast jedynie 25,9\% troską o środowisko.

Ekologizacja konsumpcji odgrywa istotną rolę w procesie kreowania innowacji przez przedsiębiorstwa. Konsumenci przejawiają nowe oczekiwania wobec produktów, które mają być nie tylko użyteczne i konkurencyjne cenowo, ale również przyjazne dla środowiska i zdrowia użytkownika. Tym samym ekologizacja oddziałuje na proces kreowania innowacji w wielu branżach, do jakich w szczególności można zaliczyć:

- $\quad$ rynek żywności, poprzez wzrost zapotrzebowania na żywność: mniej przetworzoną, o wyższych cechach jakościowych, często o regionalnym charakterze, wytwarzaną tradycyjnymi metodami;

- rynek artykułów gospodarstwa domowego, poprzez wzrost zapotrzebowania na: energooszczędne rozwiązania, w tym: pralki, zmywarki, lodówki, a zarazem bezpieczne dla zdrowia środki chemiczne, takie jak proszki do prania czy lakiery; 
- rynek artykułów budowalnych, poprzez wzrost zapotrzebowania na: oszczędne instalacje grzewcze, oświetleniowe i wodne, rozwój budownictwa pasywnego, upowszechnienie stosowania pomp ciepła;

- rynek opakowań, poprzez upowszechnienie stosowania opakowań nadających się do recyklingu lub ponownego użycia (Kiełczewski 2015, s. 57);

- $\quad$ sektor publiczny, poprzez wzrost wymagań i oczekiwań, iż procesy ekologizacji będą rozpowszechniać się w: urzędach, szpitalach, szkołach i innych instytucjach publicznych (Kiełczewski 2008).

Kolejnym, wskazanym w klasyfikacji B. Mroza trendem zachowań konsumentów, jest samoleczenie (ang. do-it-yourself-doctors). Trend ten jest związany ze wzrostem zainteresowania zdrowiem, kondycją fizyczną i psychiczną, dążeniem do kontrolowania stanu swojego organizmu. Jak pisał B. Mróz, w efekcie rosnącej świadomości ludzie: "samodzielnie diagnozują choroby i wybierają sposoby leczenia. Jeżeli decydują się na wizytę u lekarza, czynią to, aby potwierdzić lub skonsultować z lekarzem swoją diagnozę i otrzymać receptę na leki, które sami już wybrali" (Mróz 2013, s. 138). W następstwie rozwoju tego trendu: rośnie sprzedaż leków bez recepty; rozwija się medycyna alternatywna, w tym akupunktura czy ziołolecznictwo; ulega intensyfikacji sprzedaż urządzeń służących do kontroli zdrowia, w tym: ciśnieniomierzy, glukometrów, analizatorów składu ciała, urządzeń monitorowania snu czy aktywności fizycznej, takich jak krokomierze. Jednocześnie zwiększa się popularność aplikacji medycznych na telefony (Mróz 2013, s. 138-139). Zmiany te istotnie wpływają na: rynek farmaceutyczny, rynek medyczny, a także na inne rynki, np. rynek aplikacji mobilnych.

Współcześnie konsumenci stają się bardziej aktywni, poszukują informacji i poddają je krytycznej weryfikacji, co staje się możliwe w dobie rozwoju sieci internetowych. Trend trysumer odnosi się do konsumentów poszukujących i chętnie testujących nowe produkty, ponieważ współczesny konsument chce osobiście weryfikować ofertę. W rezultacie na znaczeniu tracą informacje pochodzące ze źródeł kontrolowanych marketingowo (promocja, reklama czy informacje od sprzedawcy) (Zalejski, Faszczewska 2012, s. 94). Przedsiębiorstwa świadome tego trendu mogą go doskonale wykorzystać. Przykładem jest rozwój specjalnych miejsc do wypróbowywania produktów typu Sample Lab. Początkowo idea ta rozpowszechniła się w Japonii, obecnie jest wdrażana w wielu krajach wysoko rozwiniętych. W tego typu placówkach za opłatą konsumenci mogą obejrzeć i wypróbować nowości, które jeszcze nie weszły na rynek. Zazwyczaj asortyment jest zazwyczaj szeroko zakrojony i obejmuje: odzież, kosmetyki, sprzęt sportowy, elektronikę. Dostęp do sklepu wymaga posiadania karty członkowskiej. Konsu- 
menci wnoszą niewielkie opłaty ze wypróbowanie produktów, następnie wypełniają ankiety oceniające. Produkty mogą wypróbować na terenie placówki lub poza nią, zwracając je podczas następnej wizycie (Mróz 2013, s. 140-141). Przedsiębiorstwa, oferujące możliwość wypróbowania produktów za pomocą sieci Sampling Lab, odnoszą więc podwójne korzyści. Nie tylko wykorzystują trend trysumer, wychodząc naprzeciw konsumentom poszukującym, lecz również uzyskują szybką informację zwrotną o jakości produktów. Przed ich wprowadzeniem na rynek mogą zatem skorygować ich atrybuty. Co więcej, konsumenci, korzystający z usług takich placówek, to osoby zainteresowane nowościami rynkowymi, a więc głównie innowatorzy i trendsetterzy. Wpływanie na te grupy odbiorców jest szczególnie ważne, gdy myśli się o stymulowaniu adaptacji rynkowej nowego produktu.

B. Mróz słusznie wskazał także na rosnące zainteresowanie konsumentów konsumpcją kolaboratywną, zwaną także współpracującą (ang. sharing consumption). Oznacza ona korzystanie z produktów bez konieczności nabywania ich na własność. Przejawia się: najmowaniem, wymianą, płatnym dostępem do produktów. Konsumenci skupiają się na użytkowaniu, nie zaś na posiadaniu dóbr (Botsman, Rogers 2012). Potrzebę czytania może bowiem zaspokoić dostęp do książki, a nie posiadanie książki. Podobnie, potrzebę wspinaczki górskiej może zaspokoić wypożyczenie sprzętu, a nie jego zakup. Popularna staje się zarazem tzw. własność czasowa. Polega ona na nabywaniu czasowego posiadania dóbr, a następnie ich odsprzedaży czy udostępnianiu (Mróz 2013, s. 62).

Na bazie trendu konsumpcji kolaboratywnej rozwijają się platformy typu pay per use. Wiążą się one z zapewnieniem konsumentom - za wyznaczoną opłatą - dostępu do dóbr konsumpcyjnych. W systemie tym są udostępniane samochody, mieszkania, sprzęt sportowy, markowe ubrania (Tkaczyk, Kołuda 2013, s. 26-27). Doskonałym przykładem jest system udostępniania rowerów miejskich czy rozwój samoobsługowych pralni. Czynnikiem sprzyjającym rozwojowi tego typu platform wymiany jest informatyzacja. Pozwala ona zredukować koszty transakcyjne, umożliwia wymianę produktów, kojarzy osoby chętne do wypożyczenia, z tymi, które posiadają dany produkt i chcą go udostępnić.

Zdaniem B. Mroza, do trendów zachowań konsumentów, znacząco kształtujących przyszłą konsumpcję, należy demokratyzacja luksusu, która wyraża się w zmianie sposobu jego postrzegania przez konsumentów i przedsiębiorstwa. Trend ten służy zapewnieniu możliwości korzystania z dóbr luksusowych przez szersze kręgi odbiorców, w tym przez konsumentów średnio zamożnych. Dobra tradycyjnie postrzegane jako luksusowe stają się więc bardziej dostępne. Przedsiębiorstwa mogą sprawnie wykorzystać dążenie 
konsumentów średnio zamożnych do posiadania luksusu dzięki przygotowywaniu relatywnie tanich produktów luksusowych marek, takich jak tańsze wersje wód perfumowanych, akcesoria znanych marek, np.: Chanel, Louis Vuitton, w tym: okulary, apaszki, breloczki do kluczy. Przedsiębiorstwa starają się więc dopasować asortyment do współczesnego sposobu rozumienia pojęcia luksusu przez konsumentów, aby w pełni wykorzystać potencjał rynku. Te same marki oferują zatem produkty o różnym poziomie ekskluzywności ${ }^{7}$. Z jednej strony, działanie takie pozwala maksymalizować zyski przedsiębiorców w krótkim czasie, z drugiej, może grozić zjawiskiem erozji marki. Zapobiegając temu, przedsiębiorstwa, bazujące na trendzie demokratyzacji luksusu, jednocześnie rozwijają linie superluksusowych produktów o ograniczonej ilości i dostępnych jedynie dla zamożnej grupy klientów. Doskonałym przykładem są torebki typu Birkin marki Hermes w całości wykonane ręcznie z najwyższej jakości skóry, produkowane w ograniczonych ilościach, dostępne dla wybranych klientów po wpisaniu się na listę i oczekiwaniu w kolejce.

Trend demokratyzacji luksusu może istotnie sprzyjać upowszechnianiu innowacyjnych produktów na rynku. Jedną z podstawowych cech produktów luksusowych - obok ich jakości, wyjątkowego projektu, wysokiego poziomu obsługi klienta i prestiżu - zazwyczaj jest ich innowacyjność. Umożliwienie dostępu szerszego grona odbiorców do produktów luksusowych może więc służyć akceptacji innowacji.

Z racji innowacji, za istotny trend zachowań konsumentów należy uznać technicyzację. Współcześnie przenika ona wszystkie sfery życia człowieka. Chodzi nie tylko o wykorzystanie Internetu, lecz również o zastosowanie technologii w produktach codziennego użytku. Można spodziewać się, iż w przyszłości produkty high-tech staną się produktami pierwszej potrzeby dla wielu konsumentów i zyskają szersze zastosowanie w wielu sferach życia, w tym w: pracy zawodowej, rozrywce, nauce. To zaś jest sygnałem dla przedsiębiorstw, by doskonalić ofertę, ukierunkować ją w stronę cyfryzacji i wirtualizacji (Mróz 2013, s. 155). Przykładem są: elektroniczne biblioteki, elektroniczne wersje prasy czy rozwój mobile-marketingu.

Kolejnym trendem - przeciwstawnym trendowi technicyzacji - jest cyfrowa absencja. Zgodnie z nim, część konsumentów przejawia chęć ucieczki od powszechności cyfrowych narzędzi. B. Mróz wyjaśnił, że: "konsumenci są zmęczeni, zestresowani szybkim tempem życia i koniecznością nieustannej aktywności, poniekąd wymuszonej przez cyfrowe media. Przesyt bodźców

\footnotetext{
${ }^{7} \mathrm{~W}$ tym zakresie można wymienić następujące segmenty luksusu: superluksus, luksus jako odzwierciedlenie stylu życia, luksus dostępny i luksusu dla mas (szerzej: Corbellini, Saviolo 2009, s. 113, za: Mróz 2013, s. 152).
} 
płynących z przestrzeni wirtualnej powoduje, że coraz więcej osób wybiera programową absencję od cyfrowych mediów po to, by przez pewien czas pozostać off-line bez e-maili, esemesów i dzwonków telefonów komórkowych" (Mróz 2013, s. 160). Przedsiębiorstwa mogą wykorzystywać ten trend w kampanii marketingowej. Przykładem jest kampania reklamowa Nescafe realizowana pod hasłem get a little closer, w której producent zachęca do wyłączenia elektronicznych środków komunikacji (Mróz 2013, s. 162).

Kolejnym trendem zachowań konsumentów jest natychmiastowa gratyfikacja. Polega ona na chęci natychmiastowego odczuwania przyjemności związanej z zakupem. Na znaczeniu nabiera krótkotrwała satysfakcja, co skłania do zakupów impulsywnych. Na bazie tej rozwijają się produkty typu instant, takie jak szybka żywność (gorący kubek, kawa rozpuszczalna) czy urządzenia AGD pozwalające szybko przygotować posiłek (mikrofalówka, roboty kuchenne). Rozwój trendu natychmiastowej gratyfikacji jest związany - zdaniem B. Mroza - z transferem nawyków ze świata wirtualnego do realnego. Jego rozwojowi może sprzyjać zmęczenie konsumentów naciskiem ze strony zjawisk recesyjnych, a także szybkie przenikanie amerykańskich modeli biznesowych.

Istotnym trendem - bezpośrednio związanym z heterogenizacją konsumpcji - jest hiperpersonalizacja, dotycząca rozwoju wyrafinowanych technik personalizacji oferty rynkowej. Konsumenci poszukują wysoce zindywidualizowanych produktów. Odpowiedzią na te tendencje jest dostrzegalna współcześnie fragmentaryzacja ofert rynkowych. Przejawia się ona w różnicowaniu linii produktów bądź produkowaniu znacznej ilości rodzajów określonych dóbr. Fragmentaryzacja polega na dostosowywaniu produktów do wąskich grup odbiorców oraz kierowaniu do nich jednocześnie urozmaiconych działań marketingowych (Kucharska 2014, s. 223-224).

Z hiperpersonalizacją wiąże się trend prosumpcji. Obejmuje on: "zjawisko splatania się procesów konsumpcji i produkcji, aż do zatarcia granic między nimi" (Zalega 2015, s. 21). Podstawową cechą prosumenta jest jego aktywne zaangażowanie $\mathrm{w}$ procesy produkcyjne. Jest to szczególnie istotne w kształtowaniu polityki innowacyjnej. Jak wskazał T. Zalega: „innowacyjny konsument chce być traktowany indywidualnie, chce, aby komunikować się z nim, a nie ze wszystkimi, gdyż nie wszyscy mają takie same potrzeby, upodobania i preferencje" (Zalega 2015, s. 21).

Z trendem prosumpcji, a także dążeniem do wypróbowania dóbr, łączy się rozwój konsumpcji świadomej. Współczesny konsument coraz częściej zmierza do egzekwowania swoich praw, które zna i rozumie (Wasilik 2014, s. 71). Konsumpcja świadoma oznacza również zdobywanie informacji na temat produktów i usług oraz sposobów ich wytwarzania (Zalega 2015, 
s. 19). Jeżeli konsument nie akceptuje działań danego przedsiębiorstwa, będzie dążył do ograniczania nabywania pochodzących z niego produktów. Powoduje to zainteresowanie konsumentów ograniczaniem konsumpcji z jednoczesnym przywiązaniem do produktów: prostych, funkcjonalnych, łatwych w obsłudze, trwałych (Zalega 2015, s. 31-32)

Na bazie konsumpcji świadomej rozwija się smart shopping, który polega na: inwestowaniu własnego czasu w proces zakupowy, ograniczeniu decyzji impulsywnych, porównaniu cen oraz oczekiwaniu na okazje zakupowe. Konsument planuje więc racjonalnie własny budżet i wydatki, ograniczając je do produktów niezbędnych i zaplanowanych. Istotne znaczenie ma dla niego stosunek ceny do jakości nabywanych dóbr (Zalega 2015, s. 9-10).

Obok wskazanych trendów, z punktu widzenia kształtowania polityki innowacyjnej istotna jest również juwenalizacja, która wiąże się z naśladowaniem wzorców konsumpcji charakterystycznych dla młodych grup konsumentów. Wiek przestaje być barierą w zachowaniu i konsumpcji. Powoduje to przesuwanie granic i zacieranie faz życia ludzkiego. Przestaje być on wyznacznikiem wzorców konsumpcji (Wildowicz-Giegiel 2009, s. 6).

Trend juwenalizacji prowadzi do rozwoju rynku produktów pielęgnacyjnych, usług odmładzających, w tym: usług typu DaySpa dla osób zapracowanych, suplementów diety, popularyzacji usług trenerów personalnych. Sprzyja także rozwojowi rynku tzw. żywności funkcjonalnej, obejmującej produkty spożywcze i napoje wykazujące udokumentowany, korzystny wpływ na zdrowie (Dąbrowska i in. 2015, s. 137).

Kolejnym ważnym trendem, oddziałującym na zachowania konsumentów, jest wygoda związana z dążeniem do minimalizowania uciążliwości dotyczącej konsumowania. Na jego bazie rozwija się konsumpcja leniwa, zwana zarazem wygodną. Oznacza ona większe zainteresowanie konsumentów nabywaniem produktów ułatwiających wykonywanie codziennych czynności (takich jak zmywarki do naczyń). Służy to rozwojowi rynku żywności wygodnej, obejmującej produkty gotowe do bezpośredniego spożycia lub wymagające niewielkiej obróbki kulinarnej, porcjowane i pakowane w sposób szczególnie dogodny dla konsumenta (Dąbrowska i in. 2015, s. 137).

Konsumpcja wygodna czerpie z postawy hedonistycznej, będącej kolejną cechą konsumentów początku XXI wieku. W filozofii przez hedonizm rozumie się pogląd uznający przyjemność za najwyższe dobro i cel życia. W odniesieniu do zachowań konsumentów chodzi o dążenie do odczuwania przyjemności (Sharot 2009, s. 2077-2080). Hedonizm decyduje o rozwoju oferty rynkowej w kierunku zaspokajania potrzeb związanych z osiąganiem przyjemności i komfortu, a zarazem manifestowania indywidualności. Na gruncie tym rozwijają się nietypowe produkty, które często w mniejszej 
mierze zaspokajają rzeczywiste potrzeby konsumentów, w większej zaś dostarczają im przyjemności.

Istotnym trendem w kształtowaniu polityki innowacyjnej - rozwijającym się pod wpływem technicyzacji - jest kokonizacja, zwana również domocentryzmem. Polega ona na przenoszeniu konsumpcji dóbr i usług tradycyjnie konsumowanych publicznie do przestrzeni domowej. W tym zakresie chodzi o: usługi rekreacyjne, edukacyjne, korzystanie z administracji publicznej, a nawet wizyty lekarskie. Jak zauważyła A. Matel: „Dom staje się oazą spokoju i bezpieczeństwa. Spędzanie wolnego czasu staje się swego rodzaju celebrowaniem domatorstwa" (Matel 2015, s. 22). Kokonizacja jest związana z ucieczką w prywatność konsumpcji, przy jednoczesnym uczestniczeniu w życiu społeczności za pomocą nowoczesnych technologii (Romanowski 2013, s. 22). Na bazie tego trendu rozwijają się: formy telepracy, usługi realizowane elektronicznie, e-learning czy usługi typu video-on-demand.

Konsumentów XXI wieku cechuje również poszukiwanie wrażeń oraz zmysłowość konsumpcji. Zakupy stają się formą rozrywki, a centra handlowe miejscem spędzania czasu wolnego. Konsument dąży do uzyskania poczucia ekskluzywności i bogactwa. Kupując produkty, zwraca uwagę na ich wartość symboliczną. Przejawem konsumpcji wrażeń jest efemeryzacja konsumpcji, która wyraża się w ulotności, szybkiej zmianie mody i trendów konsumenckich (Mróz 2013, s. 43). Współcześnie efemeryczny charakter przyjmują nawet przedmioty codziennego użytkowania (Burszta 2008, s. 110). Zmysłowość oznacza poszukiwanie wartości w świecie pozamaterialnym. Rozwiązaniem może być immaterializacja produktów, czyli tworzenie obiektów, które są przedmiotem zmysłowej partycypacji, jednak nie zajmują miejsca w fizycznej przestrzeni. Wiąże się więc z zastępowaniem fizycznych dóbr ich odpowiednikami wirtualnymi, które M. Krajewski nazywa cyfrowymi reprezentacjami. Do takich produktów należą wirtualne rozkłady jazdy czy wirtualne wycieczki (Krajewski 2005, s. 227).

Podsumowując, współczesne przedsiębiorstwa - odpowiadające na potrzeby dynamicznie zmieniającego się rynku odbiorców - są zmuszone stale obserwować zmiany w trendach zachowań konsumentów. Z jednej strony jest to dla nich szansa na odpowiednio wczesne reagowanie na pojawiające się potrzeby. Z drugiej strony niedostrzeżenie zmian zachodzących wśród odbiorców lub ich bagatelizacja stanowią istotne zagrożenie ${ }^{8}$.

\footnotetext{
${ }^{8}$ B. Mróz wymienił tu dwa przykłady przedsiębiorstw. Pierwszym jest przykład firmy adidas, która nie zauważyła lub zbagatelizowała szansę płynącą z rosnącej popularności joggingu, nie modyfikując oferty. Drugim jest przykład firmy IBM, która nie doceniła potencjału rynkowego komputerów osobistych, skupiając się na maksymalizacji mocy obliczeniowych superkomputerów (Mróz 2013, s. 115).
} 


\subsection{Wpływ innowacji na kształtowanie zachowań konsumentów}

Współczesne przemiany konsumpcji są warunkowane szeregiem czynników. Najczęściej wśród nich wymienia się: procesy globalizacyjne, internacjonalizację gospodarki światowej, wzrost zamożności czy starzenie się społeczeństwa. W zakresie tym zasadne jest również wyodrębnienie innowacji technologicznych jako czynnika trwale zmieniającego postawy konsumentów i wzorce konsumpcji.

Zmieniający się styl życia i nowe trendy społeczne przyczyniają się do zmian w kształtowaniu konsumpcji społeczeństwa. Konsumenci w procesie podejmowania decyzji o zakupie innowacji zwracają uwagę na różne czynniki. Do niedawna jednym z kluczowych czynników był dochód, który decydował o zakupie bądź nie danej innowacji. Jednak analizując obecne zachowania konsumentów, można dojść do wniosku, że coraz częściej o sukcesie i przyjęciu innowacji przez rynek rozstrzygają inne czynniki. Nie ulega wątpliwości, że jedną z tych determinant jest innowacja technologiczna, przez którą rozumie się zmianę $\mathrm{w}$ metodach wytwarzania oraz metodach świadczenia usług stosowanych przez przedsiębiorstwo, a także w sposobach docierania z produktem do odbiorców. Metody te mogą polegać na dokonywaniu zmian w urządzeniach lub w organizacji produkcji, mogą także stanowić połączenie tych dwóch rodzajów zmian albo być wynikiem wykorzystania nowej wiedzy. Mogą mieć one na celu produkcję albo dostarczenie nowych bądź udoskonalonych produktów, które nie mogłyby być wytworzone czy też dostarczone za pomocą metod konwencjonalnych.

Podstawową innowacją pionierską, a zarazem technologiczną, która wpłynęła na zachowania konsumentów w minionej i obecnej dekadzie, jest Internet, którego pojawienie się wywołało rewolucję w konsumpcji. Współcześnie konsumenci dzięki sieci internetowej zaspokajają szereg potrzeb, a wśród nich najczęściej wyróżnia się potrzeby związane z: kontaktami społecznymi, robieniem zakupów, korzystaniem z usług finansowych czy doradczych (Grzega 2015, s. 20).

W dobie innowacji produkowane dobra stawały się coraz tańsze, a przez to powszechnie dostępne dla większej liczby osób. Jednocześnie został zrewolucjonizowany proces zakupów. Nastąpiła transformacja, która proces kupowania uczyniła sposobem na spędzanie wolnego czasu. Internet rozwinął się w ciągu ostatnich lat do tego stopnia, że dziś niemal każdy może w jakiś sposób korzystać z tego wynalazku współczesnej cywilizacji. Internet jest obecny we wszystkich dziedzinach życia, wykorzystywany w: pracy, szkole, domu. W zasadzie bez niego nie może już funkcjonować świat biznesu (pozyskiwanie informacji o konkurencji i partnerach, komunikacja 
w czasie rzeczywistym z jednoczesnym znoszeniem bariery przestrzennej) rozrywki (gry internetowe, portale społecznościowe), nauki (e-learning, szkolenia online, audiobooki). Usługi internetowe są nieustannie doskonalone. Dzięki Internetowi jest możliwe prowadzenie wideokonferencji, a także natychmiastowy dostęp do większości informacji i danych. Przykładem może być monitorowanie stanu konta bankowego w czasie rzeczywistym. Internet stanowi jeden z najszybszych i najskuteczniejszych środków masowej komunikacji. Egzemplifikacją są serwisy informacyjne, do których ma dostęp każdy użytkownik sieci o każdej porze dnia i nocy.

Poziom wyposażenia gospodarstw domowych w zasoby, które pozwalają na korzystanie z Internetu w Polsce, w ostatnich latach istotnie wzrasta. Tym samym rośnie rola sieci w zaspokajaniu potrzeb społeczeństwa.

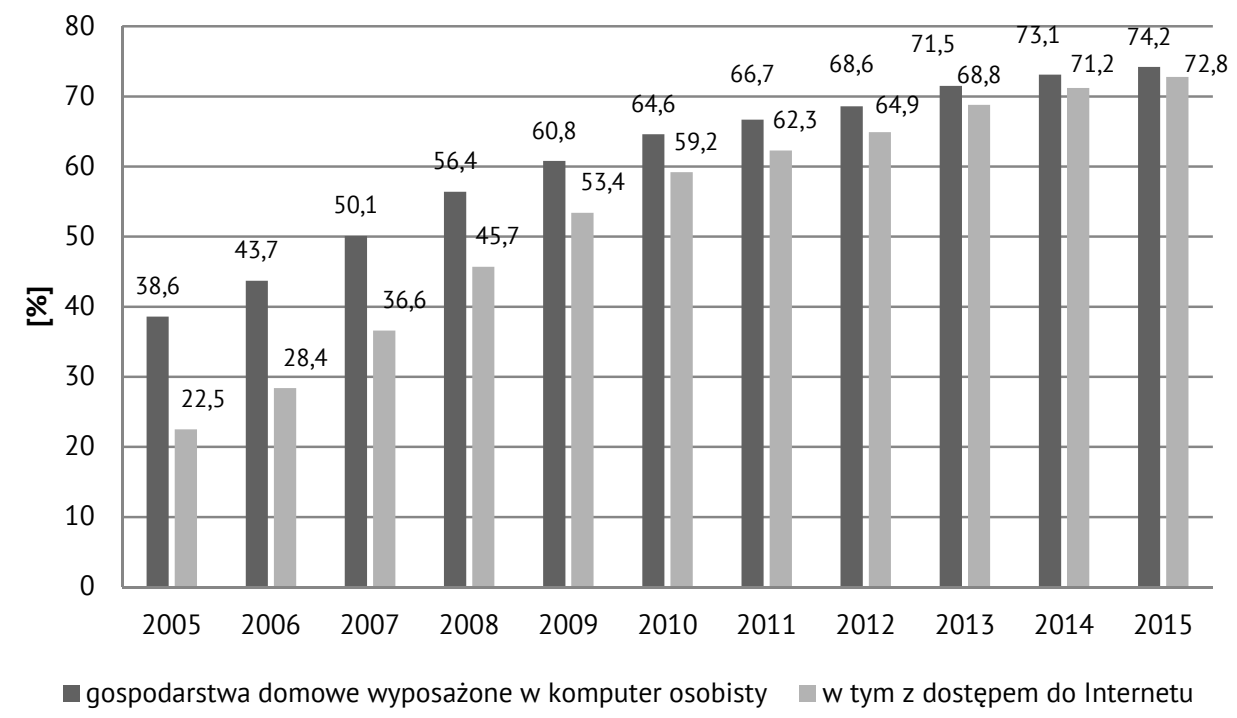

Wykres 1. Gospodarstwa domowe wyposażone w komputer osobisty, w tym z podłączeniem do Internetu w Polsce w latach 2005-2015

Źródło: opracowanie własne na podstawie: Roczniki Statystyczne Rzeczpospolitej Polskiej 2006; 2007; 2008; 2009; 2010; 2011; 2012; 2013; 2014; 2015; Mały Rocznik Statystyczny Polski 2016.

W 2005 roku, w Polsce 38,6\% gospodarstw domowych było wyposażonych w komputer osobisty, przy czym ponad co piąte gospodarstwo domowe posiadało dostęp do Internetu. W kolejnych latach następował dynamiczny wzrost zarówno udziału gospodarstw domowych wyposażonych w komputer osobisty, jak i w łącza internetowe. Był on szczególnie dynamiczny w latach 
2005-2008. W okresie tym wzrost odsetka liczby gospodarstw domowych wyposażonych w komputer osobisty wynosił średniorocznie około 12-14\%, zaś wzrost odsetka liczby gospodarstw domowych wyposażonych w łącza internetowe - około 25-29\%. Po roku 2009 wzrost ten nadal utrzymywał się, jednak ze względu na to, iż wyposażenie osiągnęło już wysoki poziom $(60,8 \%$ gospodarstw domowych wyposażonych w komputer osobisty i $53,4 \%$ a w łącza internetowe), spadła dynamika tego wzrostu. Średnioroczny wzrost wynosił około 1-5\%. W 2015 roku już trzy na cztery gospodarstwa domowe w Polsce były wyposażone w komputer osobisty, natomiast 72,8\% w łącza internetowe.

Poziom wyposażenia gospodarstw domowych zarówno w komputery osobiste, jak i łącza internetowe nie był równomierny we wszystkich grupach gospodarstw domowych.

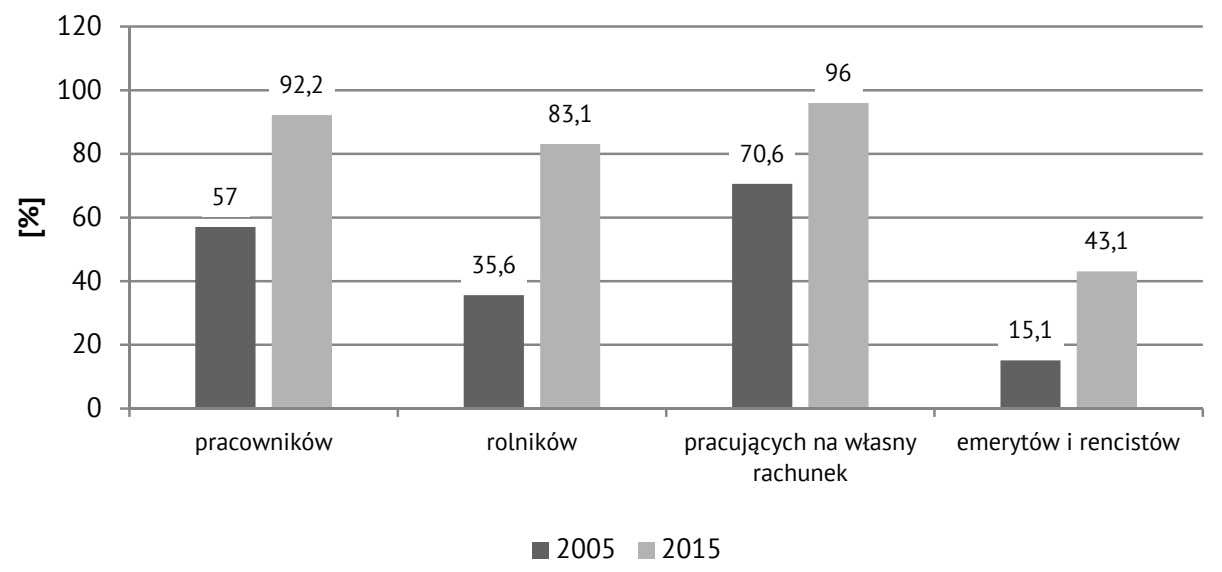

Wykres 2. Zmiana wyposażenia gospodarstw domowych w komputer osobisty w Polsce, w okresie 2005-2015 z podziałem na rodzaje gospodarstw domowych

Źródło: opracowanie własne na podstawie: Rocznik Statystyczny Rzeczpospolitej Polskiej 2006; Mały Rocznik Statystyczny Polski 2016.

W równej mierze w 2005 roku, jak i dziesięć lat później najlepiej wyposażone w komputery osobiste i łącza internetowe były gospodarstwa domowe osób pracujących na własny rachunek. Już w 2005 roku ponad 70\% tych gospodarstw domowych posiadało komputer osobisty, przy czym w 2015 roku zaledwie $4 \% \mathrm{z}$ nich nie posiadało takiego wyposażenia. Odsetek był wysoki również w gospodarstwach domowych pracowników. W latach 2005-2015 nastąpił wzrost z poziomu $57 \%$ do $92,2 \%$ gospodarstw domowych. W okresie dziesięciu lat istotnie wzrosło wyposażenie w komputer osobisty gospodarstw 
domowych rolników (z 35,6\% do 83,1\%). Znacznie spadła różnica w wyposażeniu tych gospodarstw domowych w porównaniu z gospodarstwami pracowników. Średnią krajową istotnie zaniżały gospodarstwa domowe emerytów i rencistów. W 2005 roku zaledwie 15,1\% z nich posiadało komputer osobisty, zaś do roku 2015 ich udział wzrósł do 43,1\%.

Podobnie sytuacja kształtowała się w odniesieniu do wyposażenia w komputer osobisty z dostępem do Internetu.

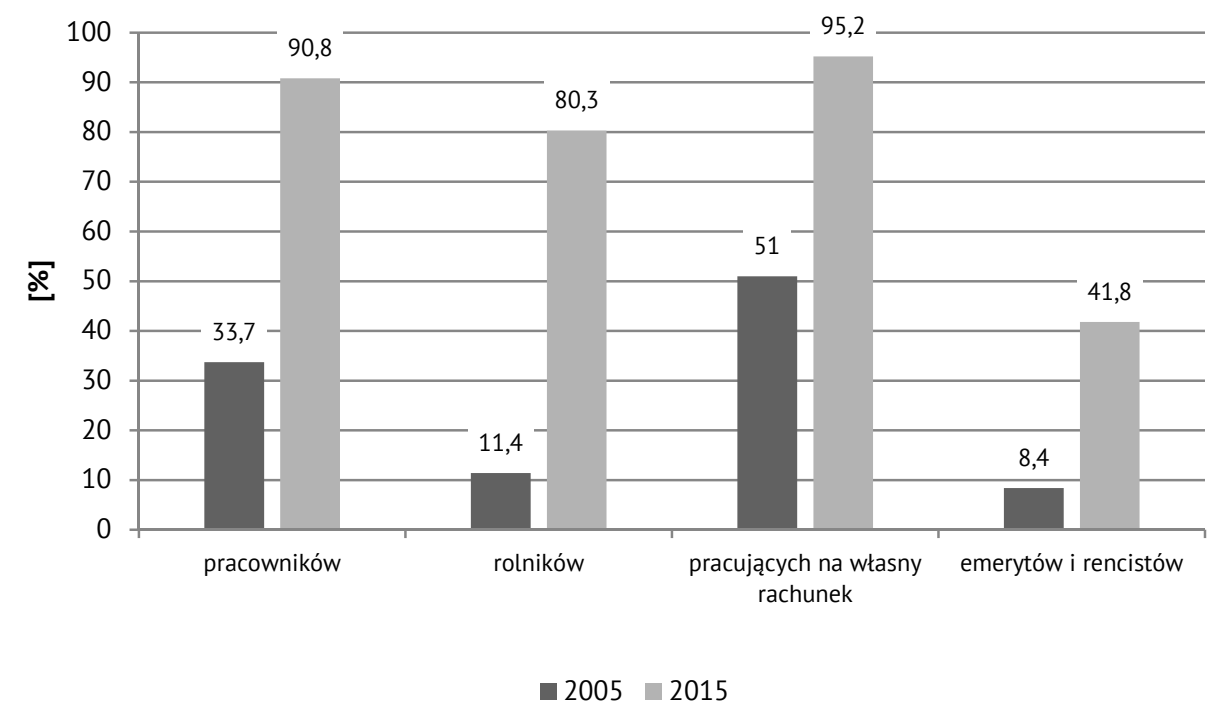

Wykres 3. Zmiana wyposażenia gospodarstw domowych w komputer osobisty z dostępem do Internetu w Polsce, w okresie 2005-2015 z podziałem na rodzaje gospodarstw domowych

Źródło: opracowanie własne na podstawie: Rocznik Statystyczny Rzeczpospolitej Polskiej 2006; Mały Rocznik Statystyczny Polski 2016.

Wzrost udziału gospodarstw wyposażonych w komputer osobisty z dostępem do Internetu w latach 2005-2015 był kluczowy w gospodarstwach domowych rolników (wzrost z poziomu 11,4\% do 80,3\%). Podobnie wyraźny wzrost odnotowano w gospodarstwach domowych emerytów i rencistów (z poziomu 8,4\% do 41,8\%), jednak nadal jest on znacznie niższy niż w pozostałych gospodarstwach domowych. W 2015 roku zaledwie 9\% gospodarstw domowych pracowników oraz 5\% gospodarstw domowych osób pracujących na własny rachunek nie posiadało dostępu do sieci. Można również zauważyć, że udział gospodarstw domowych wyposażonych w komputer osobisty, 
lecz bez dostępu do sieci, w 2005 roku był znacznie wyższy niż w 2015 roku we wszystkich grupach gospodarstw domowych.

Z racji przydatności informatyzacji w kreowaniu innowacji ważne są cele korzystania z sieci.

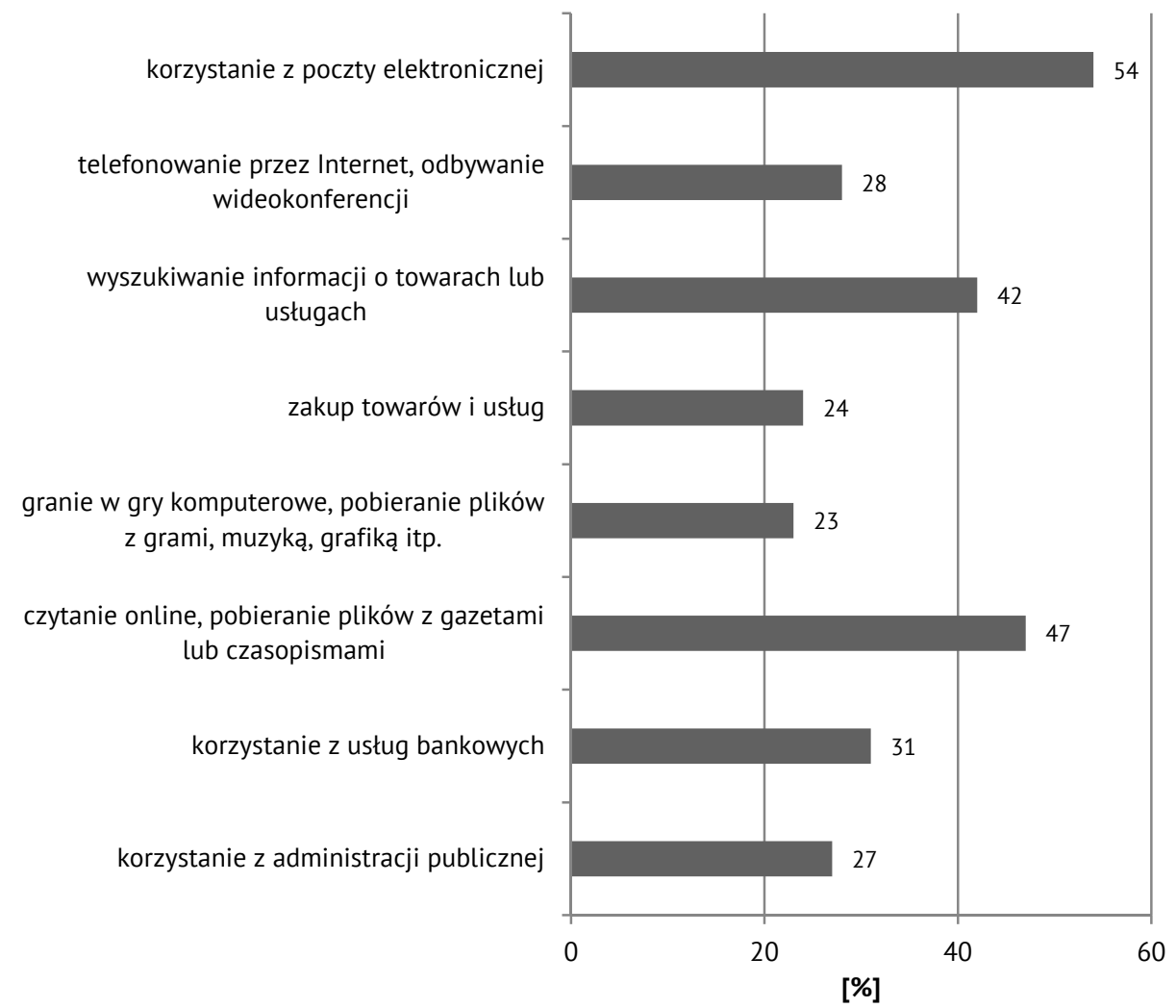

Wykres 4. Cele prywatnego korzystania z Internetu osób w wieku 16-74 lata w Polsce, w 2015 roku (jako \% ogółu osób w wieku 16-74 lata)

Źródło: opracowanie własne na podstawie: Mały Rocznik Statystyczny Polski 2016.

W 2015 roku najpopularniejszym celem korzystania Polaków z Internetu było korzystanie z poczty elektronicznej (co druga osoba w wieku 16-74 lat). Niemal połowa osób czytała online i pobierała pliki z gazetami lub czasopismami. Trzecim w hierarchii celem korzystania $\mathrm{z}$ sieci było wyszukiwanie informacji o towarach i produktach (42\% osób). Co czwarty Polak w wieku 16-74 lata w 2015 roku robił zakupy przez Internet. Oznacza to, że sieć 
odgrywa znaczącą rolę zarówno w procesie podejmowania decyzji konsumenckich, jak i ich realizacji.

Jednocześnie w prowadzeniu przedsiębiorstwa na znaczeniu zyskuje Internet.

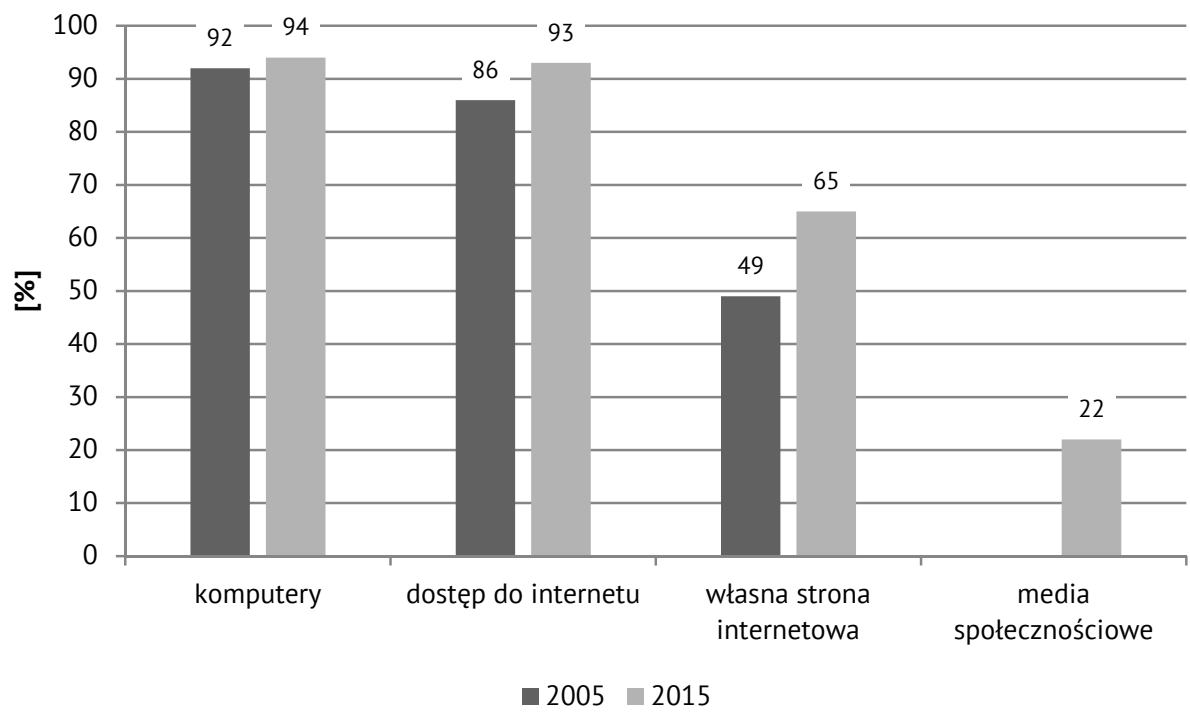

Wykres 5. Przedsiębiorstwa wykorzystujące wybrane technologie informacyjnotelekomunikacyjne w Polsce, w latach 2005 i 2016

Źródło: opracowanie własne na podstawie: Mały Rocznik Statystyczny Polski 2016.

W analizowanym okresie wzrosła rola elektronicznej komunikacji przedsiębiorstw z konsumentami. W ciągu ostatnich dziesięciu lat odnotowano wzrost o 2 punkty procentowe odsetka przedsiębiorstw wyposażonych w komputery oraz o 7 punktów procentowych odsetka przedsiębiorstw posiadających dostęp do Internetu. Zdecydowanie wzrosła jednak rola komunikacji elektronicznej. W 2015 roku dwa na trzy przedsiębiorstwa prowadziły własną stronę internetową, podczas gdy w 2005 roku posiadała ją połowa przedsiębiorstw. Nową formą komunikacji stały się media społecznościowe, które w 2015 roku wykorzystywało ponad co piąte przedsiębiorstwo.

Wskazane cele korzystania z sieci internetowej można określić w większości jako przejawy rosnącej wirtualizacji konsumpcji. K. Włodarczyk na podstawie prowadzonych badań podjął próbę budowy profilu grup konsumentów najczęściej korzystających z określonych funkcji sieci. Osoby chętnie dokonujące zakupów przez Internet, według prowadzonych badań, to kon- 
sumenci w wieku do 34. roku życia oraz osoby przebywające na urlopach, w tym macierzyńskich i wychowawczych, najczęściej mieszkające w miastach o średniej wielkości (50-100 tys. mieszkańców). Popularność tej formy zakupów była większa wśród mieszkańców północnej Polski. Z prowadzonych badań wynika, że znacznie mniejszą popularnością od zakupu produktów przez Internet cieszył się zakup usług. Dokonywały go głównie osoby w wieku 25-34 lata, z wyższym wykształceniem i o wysokich miesięcznych dochodach. Z badań wynika, iż znaczna część użytkowników sieci pozytywnie odnosi się do poszukiwania informacji o towarach i usługach w Internecie (60,9\%). Głównie byli to: przedstawiciele wolnych zawodów, właściciele firm, mieszkańcy średniej wielkości miast oraz osoby pochodzące ze stołecznego regionu Polski (Włodarczyk 2015, s. 245). Ogółem można zauważyć, że poziom wirtualizacji konsumpcji jest znacznie wyższy wśród osób młodych, co oznacza, że wiek jest ważnym czynnikiem kształtowania nowych form konsumpcji w społeczeństwie.

Wśród obszarów, na które istnienie Internetu miało największy wpływ, najczęściej wymieniono sposób komunikowania się ze znajomymi i rodziną oraz wyszukiwanie informacji i poszerzanie wiedzy; często również szybsze załatwianie spraw finansowych. Internet przede wszystkim umożliwia niemal nieograniczony dostęp do informacji, to także niezwykle rozbudowana elektroniczna encyklopedia. Codziennie w Internecie, w mgnieniu oka, miliony użytkowników sieci znajdują odpowiedzi na różne pytania, począwszy od lokalizacji pobliskiego warsztatu, przez przepisy kulinarne, historię konkretnych wydarzeń, po informacje naukowe. W świecie bez Internetu zdobycie tych informacji zajęłoby wiele godzin, a może nawet dni lub miesięcy. Wymagałoby przeanalizowania zasobów bibliotek i zasięgnięcia opinii autorytetów. Dzięki rozwojowi innowacji - która w stosunku do konsumpcji posiada charakter pionierski - wystarczy zwykle jedno kliknięcie w celu zaspokajania potrzeb związanych z dostępem do informacji.

Jednocześnie w literaturze jest podnoszona kwestia przekształcania współczesnego konsumenta w e-konsumenta, bowiem internet służy już nie tylko zaspokajaniu potrzeb. Ma zarazem udział w procesie ich pobudzania i identyfikowania, zdobywania informacji o rynku, dzielenia się tą informacją, identyfikacji możliwych sposobów zaspokojenia potrzeb (Janoś-Kresło 2006, s. 16-20). Pojęcie e-konsumenta najczęściej odnosi się do osób młodych. Ta grupa - wykorzystujących sieć w wielu sferach życia - jest nazywana w literaturze pokoleniem sieci, pokoleniem Y, następną generacją. Badania prowadzone przez D. Tapscott wśród przedstawicieli tej grupy konsumentów w dwunastu krajach (w wieku 16-29 lat, w tym m.in. w: USA, Japonii, Indiach, Hiszpanii, Brazylii) wykazały duże podobieństwa członków tego pokolenia, 
niezależnie od kultury. Tym samym wirtualizację konsumpcji uznaje się za czynnik zdolny do unifikacji zachowań nabywczych. Konsumentów pokolenia Y wyróżnia: poszukiwanie wolności i niestandardowych produktów, nastawienie eksploracyjne, wewnętrzna spójność, chęć współdziałania, włączenie rozrywki w życie codzienne oraz szybkość działania (Tapscott 1999, za: Mróz 2013, s. 73-74).

Na interesujący aspekt wpływu Internetu na konsumpcję zwrócił uwagę K. Prandecki. Jego zdaniem - w wyniku tworzenia możliwości przepływu informacji i obrazów z jednego końca świata na drugi - konsumenci są narażeni, zwłaszcza w krajach rozwijających się, na frustrację związaną z brakiem możliwości posiadania określonych dóbr. To z kolei może prowadzić do stymulowania rozwoju potrzeb konsumpcyjnych, stąd Internet staje się czynnikiem prokonsumpcyjnym (Prandecki 2013).

Konsument XXI wieku w przestrzeni wirtualnej realizuje znaczną część swojej aktywności dotyczącej nabywania produktów. Wpływ ten można rozpatrywać na różnych etapach procesu decyzyjnego (tabela 6).

Tabela 6. Internet w poszczególnych fazach procesu decyzyjnego konsumenta

\begin{tabular}{|c|c|}
\hline $\begin{array}{l}\text { Faza procesu decyzyjnego } \\
\text { konsumenta }\end{array}$ & Rola Internetu \\
\hline Faza rozpoznania problemu & $\begin{array}{l}\text { - przepływ informacji pozwalających na uświadomienie potrzeb } \\
\text { konsumpcyjnych } \\
\text { - szerzenie nowych wzorów konsumpcji (przykładowo: poprzez } \\
\text { relacjonowanie życia celebrytów, obserwację trendsetterów) } \\
\text { - rozwój ekspansji twórczej użytkowników (blog,funpage) }\end{array}$ \\
\hline Faza poszukiwania rozwiązań & $\begin{array}{l}\text { - źródło informacji o możliwych sposobach zaspokojenia potrzeb } \\
\text { (blog, funpage, sklepy internetowe) }\end{array}$ \\
\hline Faza oceny alternatyw & $\begin{array}{l}\text { - wykorzystanie porównywarek internetowych } \\
\text { - poszukiwanie informacji wśród konsumentów, którzy wypróbowali } \\
\text { już dany produkt (fora internetowe, blogi) } \\
\text { - miejsce wypowiedzi liderów opinii }\end{array}$ \\
\hline Wybór alternatywy & - zakupy online \\
\hline Ocena pozakupowa & $\begin{array}{l}\text { - dzielenie się informacją o satysfakcji lub dyssatysfakcji związanej } \\
\text { z zakupem (media społecznościowe) } \\
\text { - nawiązywanie kontaktu z przedsiębiorstwem w celu wyrażenia } \\
\text { opinii na temat produktu } \\
\text { - składanie skarg i zażaleń }\end{array}$ \\
\hline
\end{tabular}

Źródło: opracowanie własne.

Internet prezentuje możliwe wzorce zachowań i stylów konsumpcji, w tym wyznacza kierunki mody, relacjonując życie celebrytów i innych grup 
trendsetterów. Jest również miejscem ekspansji twórczej indywidualnych użytkowników, dzięki wykorzystaniu blogów czy indywidualnych kanałów Youtube. W fazie poszukiwania rozwiązań Internet dostarcza przyjaznych, łatwych w obsłudze, gotowych porównań rozwiązań. Szczególną rolę odgrywają tu: blogi, funpage'e, a także asortyment sklepów internetowych. Konsument w ocenie alternatyw wyboru może posłużyć się gotowymi porównywarkami internetowymi, zestawiającymi cechy i ceny produktów (jak ceneo.pl). Za pomocą for internetowych także może poszukiwać opinii na temat produktu wśród konsumentów, którzy go wypróbowali (jak wizaz.pl). Istotną rolę w ocenie alternatyw odgrywają liderzy opinii, którzy za pomocą sieci docierają do szerszych grup odbiorców. W fazie wyboru konsument może zrealizować zakup produktu za pomocą sieci, dokonując przy tym płatności online, a nawet korzystając z gwarancji elektronicznych. W fazie oceny pozakupowej Internet pozwala na wyrażanie własnej opinii.

Internet sprawił więc, że konsument ma możliwość realizacji każdej $\mathrm{z}$ faz procesu zakupowego bez wychodzenia z domu.

Rozwój sieci internetowej sankcjonuje potrzebę dostrzegania roli zachowań konsumentów w zarządzaniu przedsiębiorstwem, w tym w działalności innowacyjnej. B. Mróz zauważył, że Internet wyposażył konsumentów w szczególne narzędzie szybkiej i sprawnej komunikacji. Jednocześnie dał szansę na skracanie dystansu między poszczególnymi konsumentami a przedsiębiorstwami. Rozwój sieci jest więc dla konsumentów źródłem siły, umożliwiając wpływanie na przedsiębiorców, co z kolei wymusza na przedsiębiorstwach zmianę podejścia do realizacji strategii biznesowych (Mróz 2013, s. 109).

Waga innowacji pionierskiej, jaką jest Internet, uzasadnia analiza jej oddziaływania na współczesne trendy zachowań konsumentów. W istocie okazuje się, że wiele z nich rozwija się na bazie tej właśnie innowacji. Oznacza to, że Internet, tworząc przestrzeń zachowań konsumentów, istotnie oddziałuje na nowe kierunki ich rozwoju. W tabeli 7. dokonano podziału wyodrębnionych trendów zachowań za względu na siłę wpływu sieci na ich rozwój. W pierwszej kolumnie ujęto te trendy zachowań konsumentów, które rozwijają się na bazie Internetu (ich rozwój nie byłby możliwy bez rozwoju sieci). W drugiej kolumnie wyróżniono te trendy zachowań konsumentów, którym sprzyja istnienie sieci. W dużej mierze ich ekspansja jest związana z rozwojem Internetu. Co ciekawe, nie zauważono występowania trendów, które byłyby całkowicie niezależne od rozwoju sieci internetowej. Wynika to z faktu, iż w istocie w każdym z obszarów Internet pełni funkcję nośnika informacji i kreowania wzorców nowych zachowań konsumentów. Jako środek komunikacji masowej odgrywa rolę w upowszechnianiu trendów, niezależnie od ich rodzaju. 
Tabela 7. Wpływ rozwoju sieci internetowej na współczesne trendy zachowań konsumentów

\begin{tabular}{|c|c|}
\hline $\begin{array}{l}\text { Wpływ bezpośredni (zasadniczy, } \\
\text { trendy rozwijające się na bazie sieci) }\end{array}$ & $\begin{array}{c}\text { Wpływ pośredni (sprzyjający, rozwój sieci } \\
\text { sprzyja rozwojowi trendów) }\end{array}$ \\
\hline $\begin{array}{l}\text { - trend samoleczenia } \\
\text { - technicyzacja konsumpcji } \\
\text { - cyfrowa absencja } \\
\text { - hiperpersonalizacja } \\
\text { - prosumpcja } \\
\text { - smart shopping } \\
\text { - kokonizacja } \\
\text { - konsumpcja wrażeń }\end{array}$ & $\begin{array}{l}\text { - mieszanie się ptci } \\
\text { - konsumpcja kolaboratywna } \\
\text { - natychmiastowa gratyfikacja } \\
\text { - juwenalizacja } \\
\text { - konsumpcja wygodna } \\
\text { - LOHOS i ekokonsumpcja } \\
\text { - trysumer } \\
\text { - demokratyzacja luksusu }\end{array}$ \\
\hline
\end{tabular}

Źródło: opracowanie własne.

Trend samoleczenia rozwija się pod wpływem łatwego i szybkiego dostępu do informacji dotyczącej stanu organizmu. Internet dostarcza wiedzy w zakresie rozpoznania i diagnozy stanu zdrowia w łatwej, przystępnej formie. Rozwój sieci jest źródłem postaw technocentrycznych, zwłaszcza wśród młodych konsumentów, co wiąże się z pozytywną oceną wszystkiego, co jest rezultatem najnowszej technologii (Patrzałek 2014, s. 266). Powszechność sieci powoduje dążenie do uzyskania - najczęściej chwilowej - cyfrowej absencji. Internet, dzięki znacznemu skróceniu kanałów komunikacji między przedsiębiorstwem a konsumentem, dał możliwość hiperpersonalizacji. Indywidualne dostosowanie produktów przez duże korporacje nie byłoby możliwe bez komunikacji elektronicznej. Co więcej, sieć sprzyja indywidualizacji odbioru treści kulturowych. Powoduje, że konsument może dowolnie wybierać treści przekazu, jak również stać się ich twórcą (Kowalska 2015, s. 66).

$\mathrm{Na}$ bazie sieci rozwija się również prosumpcja, Internet dostarcza bowiem narzędzi pozwalających na angażowanie konsumenta w procesy produkcyjne. To właśnie aktywność konsumentów w sieci prowadzi do stopniowego zacierania się granicy między producentami a konsumentami, a także włączania konsumentów w procesy produkcyjne. Stwarza on możliwość szybkiego pozyskiwania informacji i dzielenia się nią (Kowalska 2015, s. 66).

Bez rozwoju sieci internetowej byłby zarazem ograniczony rozwój smart shoppingu. To właśnie popularność Internetu, w tym głównie social media, umożliwia sprawne porównywanie ofert rynkowych, dzielenie się wiedzą, wyszukiwanie miejsc najbardziej korzystnego zakupu. G. Koniorczyk stwierdził: "Internet wraz z mobilnymi urządzeniami stanowią idealne narzędzia, dzięki którym sprytni konsumenci mogą sprawniej zorganizować oszczędne 
zakupy" (Koniorczyk 2014, s. 18-19). Ponadto, Internet pozwala na skierowanie kampanii (w tym w postaci bojkotów konsumenckich) przeciwko przedsiębiorstwom prowadzącym działalność społecznie nieodpowiedzialną, a nawet społecznie szkodliwą (Tkaczyk, Kołuda 2013, s. 37). Rozwój sieci odgrywa podstawową rolę w kształtowaniu kokonizacji konsumpcji. Wirtualizacja konsumpcji stała się źródłem przenoszenia szeregu aktywności w przestrzeń domową. Dzięki możliwości komunikacji elektronicznej dom może stać się: miejscem pracy, nauki, przestrzenią dokonywania zakupów, kontaktu z administracją, prywatą siłownią, miejscem odpoczynku czy spotkań towarzyskich (Kowalska 2015, s. 69-71).

Poza trendami, które bezpośrednio rozwijają się na bazie sieci internetowej można wskazać również takie, w stosunku do których wpływ ten jest pośredni. Internet przede wszystkim sprzyja rozwojowi trendu polegającego na poszukiwaniu wrażeń. Trend ten - jak wskazali S. Tkaczyk, J. Kołuda - jest związany z: rosnącym zainteresowaniem grami internetowymi, wszelkiego rodzaju symulacjami, programami typu reality show, telewizją interaktywną, parkami rozrywki (Tkaczyk, Kołuda 2013, s. 28). Rozwój sieci daje także techniczne szanse na rozwój konsumpcji kolaboratywnej. W tym celu są tworzone specjalne platformy internetowe, kojarzące osoby posiadające dobro z osobami chcącymi z niego skorzystać (przykładowo platformy wymiany książek). To z kolei - jak już wskazano - umożliwia obniżenie kosztów transakcyjnych wymiany. Ważną cechą Internetu jest funkcjonowanie w czasie rzeczywistym, co powoduje, że konsumenci otrzymują szybką gratyfikację, a to kształtuje oczekiwania względem konsumpcji. Co więcej, Internet tworzy warunki do rozwoju tzw. konsumpcji wygodnej. Pozwala na korzystanie z szeregu usług oraz nabywanie dóbr bez wysiłku, bez wychodzenia z domu. Wirtualizacja konsumpcji ma znaczenie w upowszechnianiu trendu mieszania: płci, juwenalizacji i ekokonsumpcji, dzięki monitorowaniu i relacjonowaniu zachowań trendsetterów, w tym głównie celebrytów, i szerzeniu poglądów tzw. liderów opinii. Prowadzi to do wykreowania mody na określone zachowania.

Biorąc pod uwagę zaprezentowany wpływ innowacji technologicznych na zmiany zachowań konsumentów, można zastanowić się, kto w istocie jest kreatorem nowych trendów. Jak stwierdził U. Grzega: „Głównymi kreatorami (...) są reklamodawcy i reklamy, którzy na indywidualne potrzeby wyrażania 'siebie' odpowiadają gotowymi do wykorzystania pakietami konsumpcyjnymi. Bardzo duże znaczenie w tych procesach ma doświadczenie zapośredniczone - z zasadniczą rolą środków masowego przekazu (...). Udzielają [one - przypis autorek] wskazówek dotyczących nie tylko ubioru, sposobu odżywiania się czy obyczajów, lecz także wzorców związanych z podstawowymi 
rolami i obszarami życia. Pokazują np. jak powinien wyglądać wspaniały ślub, jak być nowoczesną mamą, jak funkcjonować w pracy, po pracy i w ogóle jak żyć. W takim właśnie zniekształconym przez konsumpcję kontekście działalność indywidualnych podmiotów konsumpcji zaczyna skupiać się na idei 'mieć'. Nie ma przy tym znaczenia, czy wykreowane potrzeby są 'prawdziwe' czy 'sztuczne' i 'fałszywe'." (Grzega 2015, s. 17).

Należy stwierdzić, że wpływ innowacji na zmiany zachowań konsumentów jest zróżnicowany. Podejście konsumentów w zakresie zmian swoich dotychczasowych decyzji związanych z konsumpcją wielu produktów jest indywidualne. Nowy produkt, jego zakup i użytkowanie przez konsumentów zmienia zarówno preferencje konsumentów, postawy w stosunku do towarów, zwyczaje zakupowe, jak i style stosowania. Można wyodrębnić istotne elementy w stosunku do poszczególnych etapów procesu zakupu nowego produktu. Stanowią one jednocześnie zbiór najważniejszych elementów, które oddziałują na zachowania konsumentów na danym rynku.

Zachowania na rynku w znacznym stopniu są uwarunkowane z jednej strony przez wskazane wcześniej czynniki, z drugiej przez strategie marketingowe realizowane przez przedsiębiorców. Mimo że wiedza i doświadczenie konsumenta kształtują długookresową świadomość konsumentów, to działania marketingowe przedsiębiorstw w dużym stopniu są odpowiedzialne za zachowania spontaniczne, niejednokrotnie zmieniające przyjęty wzorzec i tendencje. Duże zróżnicowanie procesów adaptacji innowacyjnych produktów stanowi istotne wskazówki dla przedsiębiorstw funkcjonujących na rynku. Konserwatyzm w przyjmowaniu innowacji wymaga maksymalnego dostosowania działań marketingowych do rozpoznanych reakcji konsumentów (Gałązka 2015, s. 120).

Wiedza o zachowaniach konsumentów i uwarunkowaniach tych zachowań na rynku jest niezbędna do budowania strategii marketingowej przedsiębiorstwa funkcjonującego na rynku, jak również do opracowania metod aktywnego oddziaływania i kształtowania zachowań wybranej grupy odbiorców. Sprowadza się to do podejmowania działań operacyjnych, realizowanych w ramach skonstruowanej strategii. Zaproponowana strategia kształtowania zachowań konsumentów powinna polegać na bardzo elastycznym dostosowywaniu się do zmian otoczenia i wpływaniu na rynek.

Ważnym elementem wyływania na zachowania konsumentów są działania podejmowane przez producentów, które mają na celu poszerzenie dotychczasowego asortymentu. Uzupełnianie oferty rynkowej o dodatkowe rodzaje, formy i funkcje pozwala docierać do różnych segmentów konsumentów, różniących się upodobaniami i wymaganiami dotyczącymi produktu. 
Elementem, który w zasadniczy sposób może wpływać na zachowania konsumentów i w dużej mierze zależy od wyborów menedżerów przedsiębiorstw, jest dystrybucja. Nowoczesne podejście do dystrybucji postrzega ten instrument oddziaływania na rynek jako komfort zapewniony konsumentowi. W tym kontekście możliwość wpływu na zachowania konsumentów ujawnia się w postaci zapewniania warunków prezentacji produktu w sposób pożądany przez konsumenta. Ponadto, współczesny konsument funkcjonuje w coraz większym chaosie komunikacyjnym. Codziennie dociera do niego kilkadziesiąt różnych komunikatów, z których większość pozostaje niezauważona. Wymaga to poszukiwania oryginalnych sposobów zarządzania i kształtowania uwagi konsumenta. Tradycyjne narzędzia promocji okazują się coraz bardziej zawodne - dlatego też, w celu zwiększenia skuteczności kształtowania zachowań konsumentów, należy ograniczać tradycyjne sposoby komunikowania na rzecz nowych rozwiązań (Bylok 2013, s. 113-115).

Ciekawe możliwości wpływu na zmiany zachowań konsumentów na rynku stwarza koncepcja zarządzania autentycznością i oryginalnością. Zarządzanie autentycznością to świadome wykorzystywanie dostępu do unikalnych produktów i uświadamianie tego otoczeniu rynkowemu - kierowanie ofertą rynkową tak, aby ten unikalny produkt spożytkować. W koncepcji zarządzania autentycznością celem jest: całościowe wykreowanie wizerunku autentycznego produktu, eksponowanie promocyjne argumentu niepowtarzalności, a także określenie przewagi konkurencyjnej opartej na unikalności. Realizacja tych celów dzięki odpowiedniej strategii marketingowej jest możliwa i może przyczynić się do zmiany postrzegania oferty produktowej na badanym rynku przez konsumentów. Jednak nie jest to nic innego, jak produkt innowacyjny, nazywany oryginalnym lub niepowtarzalnym.

Fundamentalnym instrumentem oddziaływania na zachowania konsumentów jest innowacyjny produkt zintegrowany, który zyska akceptację konsumentów. Produkt ten posiada takie atrybuty, jak: kompatybilność, złożoność, możliwość wypróbowania, możliwość obserwacji i przekazywalność, postrzegalność ryzyka, co w konsekwencji wpływa na przyspieszenie procesu dyfuzji. 


\section{Zakończenie}

Wnioski z rozważań nad zależnościami między zachowaniami konsumentów a działalnością innowacyjną przedsiębiorstw można sformułować w poniższy sposób.

\section{Przebieg procesu akceptacji innowacji przez konsumentów obejmuje} fazę poznawczą, afektywną oraz behawioralną i różni się w zależności od indywidualnych cech konsumentów.

Zarówno spektakularne sukcesy rynkowe, jak i porażki innowacyjnych produktów dowodzą, że proces akceptacji danego produktu przez konsumentów jest jednym z wyznaczników efektywności działalności innowacyjnej przedsiębiorstw. Proces akceptacji innowacji przez konsumentów składa się z trzech podstawowych faz. Pierwszą z nich jest faza poznawcza, w której może dojść do odrzucenia pasywnego, bez zapoznania się konsumentów z ofertą. W drugiej fazie (afektywnej) konsumenci kształtują oczekiwania w stosunku do nowego produktu i wykazują zainteresowanie jego nabyciem. W fazie behawioralnej podejmują decyzję o nabyciu produktu lub zaniechaniu kupna (odrzucenie aktywne). Podstawowymi warunki akceptacji nowego produktu są pozytywne postawy wobec nowości oraz dysponowanie odpowiednim poziomem dochodów rozporządzalnych.

\section{Szczególną rolę $w$ procesie akceptacji rynkowej innowacji odgrywają} konsumenci-innowatorzy.

Innowacyjność konsumentów określa ich stosunek do nowości rynkowych. W literaturze pojawiło się kilka propozycji klasyfikacji konsumentów pod względem postaw wobec nowości rynkowych. Większość z nich wyróżnia grupę konsumentów-innowatorów oraz grupę konsumentów niechętnie przyjmujących nowe produkty (zwanych często "maruderami"). Konsumenciinnowatorzy oddziałują na akceptację nowych produktów wśród innych grup konsumentów na dwa sposoby. Pierwszym jest szerzenie pozytywnych opinii na temat nowych produktów, a tym samym ograniczanie niepewności związanej $\mathrm{z}$ ich nabyciem. Drugi zaś to demonstracja określonych wzorców zachowań. Oznacza to, że konsumenci-innowatorzy tworzą rynek zbytu dla nowych produktów, początkowo przez manifestowanie ich użytkowania, 
a następnie dzięki popularyzowaniu pozytywnego nastawienia do nich. Są to jednostki wymagające, świadome swoich potrzeb, jednocześnie kierujące się dążeniem do zdobywania i utrzymania prestiżu społecznego. Produkt innowacyjny, który w lepszy nich dotychczas sposób zaspokaja potrzeby odbiorców, a co za tym idzie, spełnia ich wymagania, ma szanse zostać zaakceptowany, a pozytywna opinia o nim zostanie przekazana na rynek. Badania wykazują, że wśród polskich konsumentów jedynie niewielka część przejawia innowacyjne zachowania. Zazwyczaj są to ludzie młodzi, mieszkańcy miast.

\section{Poziom akceptacji innowacji rynkowych przez konsumentów może być rozpatrywany zarówno w ujęciu makro-, jak i mikroekonomicznym.}

Wysoka skłonność konsumentów do akceptacji innowacji sprzyja przede wszystkim szybkości adaptacji rynkowej nowych produktów. Jest czynnikiem motywującym przedsiębiorstwa do wdrażania zmian, co w konsekwencji stymuluje rozwój innowacyjności. Jednak wysoka skłonność do akceptacji niepewności wśród konsumentów jest dla nich szansą na lepsze zaspokojenie potrzeb. W wymiarze społecznym zachowania konsumentów-innowatorów pozwalają na ograniczenie tej niepewności dzięki dostarczaniu opinii na temat cech produktów.

\section{Innowacyjność konsumentów jest złożonym zjawiskiem determinowanym} przez szereg czynników, wśród których istotną rolę odgrywają w równej mierze cechy indywidualne, jak i cechy charakterystyczne dla całych społeczności.

Na innowacyjność konsumentów wpływ wywiera szereg czynników. W celu ich usystematyzowania dokonano podziału na uwarunkowania: psychologiczne, demograficzne, społeczne, kulturowe (często ujmowane łącznie jako determinanty społeczno-kulturowe), ekonomiczne i marketingowe. Wśród czynników psychologicznych istotne są cechy osobowościowe konsumentów, takie jak: skłonność do ryzyka, wiara w siebie, niezależność, a także rodzaj potrzeb zaspokajanych przez innowacyjny produkt. Wyniki badań wtórnych wykazały, że innowacyjność konsumentów jest również warunkowana czynnikami demograficznymi, takimi jak: płeć, wiek czy pochodzenie. Jednocześnie są istotne wpływy społeczne, w tym wpływ trendsetterów i cykl życia, w jakim znajduje się rodzina. Poziom akceptacji nowego produktu wśród konsumentów jest związany zarazem z panującą modą i normami przyjętymi w społeczeństwie. 


\section{Konsumenci powinni być postrzegani jako jeden z zasobów organizacji wdrażających innowacje rynkowe.}

Współcześnie można dostrzec, że zachowania konsumentów są uwzględniane w wielu modelach innowacyjności, w tym w modelach proponowanych przez: P.F. Druckera, D. Smitha czy W.M. Cohena i D.A. Lewinthala. W większości z nich konsumenci nie są ujmowani jako pasywni odbiorcy działań przedsiębiorstw, lecz jako współkreatorzy innowacji. Realizacja idei innowacyjnej gospodarki opartej na wiedzy wymaga takiego właśnie ich postrzegania. Oznacza to, że obok gromadzenia, przetwarzania i wykorzystania informacji o konsumentach, również ważne staje się angażowanie ich w procesy produkcyjne oraz wykorzystywanie ich kreatywności i twórczości, co staje się możliwe dzięki rozwojowi sieci internetowej. Konsumenci, dzięki nowoczesnym technologiom (Internet, smartfon), stają się aktywnymi partnerami przedsiębiorców, tzn. współtworzą produkty, a następnie je nabywają. To właśnie Internet jest innowacją, która ma podstawowy wpływ na zachowania konsumentów i ich decyzje na rynku. Producenci zmuszeni są zatem do obserwacji wszelkich zmian w trendach konsumenckich i dynamicznego reagowania na nie. Polega to nie tylko na wykorzystywaniu informacji o zachowaniach konsumentów, ale także angażowaniu ich w procesy produkcyjne.

\section{Przedsiębiorstwa mogą wykorzystać wiedzę o nowych trendach zachowań konsumentów w procesie kreowania innowacji.}

Zaprezentowane w monografii trendy w zachowaniu konsumentów, takie jak: dbałość o zdrowie i dobrą kondycję, homogenizacja, ekokonsumpcja, prosumpcja czy heterogenizacja, wyraźnie pokazują, że obecnie konsumpcja nabiera zupełnie innego znaczenia. Potrzeby konsumentów ewoluują pod wpływem szeregu czynników, w tym związanych z: rozwojem gospodarczym, przemianami kulturowymi, globalizacją. Przedsiębiorstwo, w wyniku analizy tych zmian zyskuje szansę na kreowanie produktów w większym stopniu dostosowanych do potrzeb konsumentów.

\section{Równolegle z wpływem konsumentów na innowacje uwidacznia się wpływ innowacji na zmiany zachowań konsumentów.}

We współczesnej gospodarce zależność między zachowaniami konsumentów a innowacjami ma charakter zwrotny. Z jednej strony konsumenci wywołują zmiany w działalności innowacyjnej przedsiębiorstw, z drugiej - innowacje zmieniają zachowania konsumentów. Wiele współcześnie diagnozowanych trendów wykształciło się za sprawą rozwoju sieci internetowej. Wśród nich można wymienić trend: samoleczenia, technicyzacji konsumpcji, cyfrowej absencji, hiperpersonalizacji, prosumpcji, smart shopping, kokonizacji i konsumpcji wrażeń. 
Podsumowując, wciąż zmieniające się warunki funkcjonowania gospodarki wymagają podejmowania rozwiązań innowacyjnych przez poszczególne podmioty. Najistotniejszym zjawiskiem jest innowacyjność przedsiębiorstw, których pozycja rynkowa jest uzależniona z jednej strony od wprowadzania innowacyjnych produktów odpowiadających potrzebom konsumentów, z drugiej od kontaktu z odbiorcami. Chodzi tu mianowicie o postrzeganie tych ostatnich nie tyle jako odbiorców, co jako kreatorów innowacji, to natomiast przyczynia się do wygenerowania bądź zwiększenia popytu na określone produkty. 


\section{Literatura}

1. Abernathy W.J., Utterback J.M. (1978), Patterns of industrial innovation, "Technology Review", vol. 80, no. 7.

2. Badowska S. (2016), Innowacyjność konsumentów seniorów w świetle badań własnych, "Zarządzanie i Finanse. Journal of Management and Finance", vol. 1.

3. Balsano T.J., Goodrich N.E., Lee R.K., Miley J.W., Morse T.F., Roberts D.A. (2008), Identify your innovation Enablers and Inhibitors, "Reasearch Technology Management", no. 51 (6).

4. Barczak B., Walas-Trębacz J. (2007), System informacyjny w procesie innowacyjnym, Wydawnictwo Akademii Ekonomicznej w Krakowie, Kraków.

5. Baruk J. (2002), Co utrudnia działalność innowacyjna w małych i średnich przedsiębiorstwach?, [w:] Komputerowo zintegrowane zarzqdzanie, R. Knosala (red.), Wydawnictwo Naukowo-Techniczne, Warszawa.

6. Baruk J. (2005), Co pobudza przedsiębiorstwa do wprowadzania innowacji, "Przegląd Organizacji", nr 7-8.

7. Baruk J. (2006), Zarzq̨dzanie wiedzq i innowacjami, Wydawnictwo Adam Marszałek, Toruń.

8. Bauman Z. (2004), Życia na przemiał, Wydawnictwo Literackie, Warszawa.

9. Beaudoin P., Lachance M.J., Robitaille J. (2003), Fashion Innovativeness, Fashion Diffusion and Brand Sensitivity among Adolescents, "Journal of Fashion Marketing and Management", vol. 7, no. 1.

10. Begg D., Fischer S., Dornbusch R. (2007), Ekonomia. Mikroekonomia. Tom 1, Polskie Wydawnictwo Ekonomiczne, Warszawa.

11. Białoń L. (2010), Zręby teorii innowacji. Firma innowacyjna, [w:] Zarządzanie działalnościa innowacyjna, L. Białoń (red.), Agencja Wydawnicza „Placet", Warszawa.

12. Bierfeleder W. (1981), Enstehung Und Ausbreitung von technischen Neurungen, [w:] Von den Bereitschaft zum technischen Wandel, E. Hofmeister, M. Ulbricht (rd.), Siemens Aktiengessellschaft, Berlin und Munchen.

13. Bocian A.F. (2009), Globalizacja i regionalizacja jako wyzwanie dla polityki gospodarczej, "Optimum. Studia Ekonomiczne", nr 4(44).

14. Bogdanienko J. (2004a), Innowacje jako czynnik przewagi konkurencyjnej, [w:] Innowacyjność przedsiębiorstw, J. Bogdanienko, M. Haffer, W. Popławski (red.), Wydawnictwo Uniwersytetu Mikołaja Kopernika, Torun.

15. Bogdanienko J. (2004b), Innowacyjność przedsiębiorstw, Wydawnictwo Uniwersytetu Mikołaja Kopernika, Toruń. 
16. Bombol M. (2006), Potrzeby konsumenta, [w:] Konsument i konsumpcja we współczesnej gospodarce rynkowej, M. Janoś-Kresło (red.), Oficyna Wydawnicza Szkoły Głównej Handlowej w Warszawie, Warszawa.

17. Botsman R., Rogers R. (2012), What's mine is yours: The Rise of Collaborative Consumption, Harper Collins, New York.

18. Bratnicki M. (1998), Transformacja przedsiębiorstwa, Wydawnictwo Akademii Ekonomicznej w Katowicach, Katowice.

19. Burgiel A. (2014), Społeczne zjawiska w zachowaniach polskich konsumentów. Oddziaływania społeczne, naśladownictwo, ostentacja i snobizm, Wydawnictwo Uniwersytetu Ekonomicznego w Katowicach, Katowice.

20. Burszta J. (2008), Świat jako więzienie kultury, Państwowy Instytut Wydawniczy, Warszawa.

21. Bylok F. (2002), The Influence of Globalization Processes on Direction of Development for Enterprises, [in:] Economic Aspects of Industrial Reconversation, M. Nowicka-Skowron, R. Lescroart (eds.), Book Review Editors, Virton.

22. Bylok F. (2005), Konsumpcja w Polsce i jej przemiany w okresie transformacji, Wydawnictwo Politechniki Częstochowskiej, Częstochowa.

23. Bylok F. (2013), Konsumpcja, konsument i społeczeństwo konsumpcyjne we współczesnym świecie, Wydawnictwo Politechniki Częstochowskiej, Częstochowa.

24. Bylok F. (2015), Prosumpcja jako forma innowacji na współczesnym rynku, [w:] Konsumpcja i innowacje, A. Olejniczuk-Merta (red.), Marketing i Rynek, Warszawa.

25. Bywalec Cz., Rudnicki L. (1999), Podstawy ekonomiki konsumpcji, Wydawnictwo Akademii Ekonomicznej w Krakowie, Kraków.

26. Bywalec Cz., Rudnicki L. (2002), Konsumpcja, Polskie Wydawnictwo Ekonomiczne, Warszawa.

27. Ciborowski R. (2012), Modele rozwoju innowacyjnego, [w:] Ekonomika i zarzqdzanie innowacjami w warunkach zrównoważonego rozwoju, A.H. Jasiński, R. Ciborowski (red.), Wydawnictwo Uniwersytetu w Białymstoku, Białystok.

28. Ciborowski R. (2004), Wpływ zmian w polityce ekonomicnej i globalizacji na postęp techniczny i konkurencyjność gospodarki Wielkiej Brytanii, Wydawnictwo Uniwersytetu w Białymstoku, Białystok.

29. Chesbrough H.W. (2003), Open Innovation. The New Imperative for Creating and Profiting from Technology, Harvard Business School Press, Boston.

30. Chesbrough H.W. (2002), Graceful Exits and Foregone Opportunities: Xerox's Management of its Technology Spin-off Companies, "Business History Review", no. 4.

31. Cohen W.M., Lewinthal D.A. (1990), Absorptive capacity: A new perspective on learning and innovation, "Administrative Science Quarterly", vol. 35. 
32. Corbellini E., Saviolo S. (2009), Managing Fashion and Luxury Companies, ETAS, Milano.

33. Cotte J., Wood S.L. (2004), Families and Innovative Consumer Behavior: A Triadic Analysis of Sibling and Paternal Influence, "Journal of Consumer Research", vol. 31, no. 1.

34. Dąbrowska A., Bylok F., Janoś-Kresło M., Kiełczewski D., Ozimek I. (2015), Kompetencje konsumentów. Innowacyjne zachowania. Zrównoważona konsumpcja, Polskie Wydawnictwo Ekonomiczne, Warszawa.

35. Dąbrowski J., Koładkiewicz I. (1998), Praktyki innowacyjne polskich przedsiębiorstw, Wydawnictwo WSPiZ, Warszawa.

36. Domurat A., Zieliński T. (2013), Niepewność i niejasność jako uwarunkowania decyzji ekonomicznych, "Decyzje”, nr 20.

37. Drucker P.F. (1992), Innowacje i przedsiębiorczość. Praktyka i zasady, Polskie Wydawnictwo Ekonomiczne, Warszawa.

38. Drucker P. F. (2004), Dyscyplina w podejściu do innowacji, „Harvard Busines Review Polska", nr 1.

39. Działalność innowacyjna przedsiębiorstw w latach 2013-2015, (2016), GUS Warszawa.

40. Ellsberg, D. (1961), Risk, ambiguity, and the Savage axioms, "Quarterly Journal of Economics", no. 75(4).

41. Engel J.F., Blackwell R.D., Miniard P.W. (1993), Consumer Behavior, The Dryden Press, Chicago.

42. Escher I., Petrykowska J. (2014), Zachowania młodych polskich konsumentów na rynku żywności ekologicznej, "Zeszyty Naukowe Uniwersytetu Szczecińskiego. Problemy Zarządzania, Finansów i Marketingu", nr 36.

43. Evans F.B. (1959), Psychological and objective factors in the prediction of brand choice, "Journal of Business", no. 32.

44. Falkowski A., Tyszka T. (2006), Psychologia zachowań konsumenckich, Gdańskie Wydawnictwo Psychologiczne, Gdańsk.

45. Falkowski A., Tyszka T. (2009), Psychologia zachowań konsumenckich, Gdańskie Wydawnictwo Psychologiczne, Gdańsk.

46. Fisk P. (2009), Geniusz konsumenta. Prowadzenie firmy skoncentrowanej na oczekiwaniach nabywców, Oficyna a Wolters Kluwer Business, Warszawa.

47. Foxall G. (1984), Corporate Innovation: Marketing and Strategy, St. Martin's Press, New York.

48. Foxall G.R., Goldsmith R.E. (1998), Psychologia konsumencka dla menedżera marketingu, Wydawnictwo Naukowe PWN, Warszawa.

49. Francik A., Pocztowski A. (1991), Procesy innowacyjne, Wydawnictwo Akademii Ekonomicznej w Krakowie, Kraków.

50. Freeman Ch. (1986), The Role of Technical Change in National Economic Development, [w:] Technological Change, A. Amin, J. Goddard (eds.), Industrial Restructuring and Regional Development, Allen\&Unwin, London. 
51. Friedman T.L. (2006), Świat jest płaski. Krótka historia XXI wieku, Rebis, Poznań.

52. Fuller J., Bartl M., Ernst H., Muhlbacher H. (2006), Community based innovation: How to integrate members of virtual communities into new product development, "Electron Commerce Research", no. 6.

53. Galbraith J.K. (1973), Społeczeństwo dobrobytu. Państwo przemysłowe, Państwowy Instytut Wydawniczy, Warszawa.

54. Gałązka M. (2015), Ekonomiczne i społeczne determinanty wydatków na żywność w Polsce, Wydawnictwo Kujawsko-Pomorskiej Szkoły Wyższej, Bydgoszcz.

55. Garbarski L. (1998), Zachowania nabywców, Polskie Wydawnictwo Ekonomiczne, Warszawa.

56. Gardocka-Jałowiec A. (2015a), Gospodarowanie środkami konsumpcji a zdolność kreowania działalności innowacyjnej w gospodarce, [w:] Konsumpcja i innowacje, A. Olejniczuk-Merta (red.), Marketing i Rynek, Warszawa.

57. Gardocka-Jałowiec A. (2015b), Rola konsumpcji w kreowaniu innowacji, "Konsumpcja i rozwój", nr 3(12).

58. Gardocka-Jałowiec A. (2015c), Zmiany w konsumpcji a kreowanie innowacji, Wydawnictwo Uniwersytetu w Białymstoku, Białystok.

59. Gloet, M., Samson, D. (2013), Knowledge Management to Support Systematic Innovation Capability, http://www.hicss.hawaii.edu/hicss_46/bp46/ks4. pdf (data wejścia: 22.03.2017).

60. Gonet D. (2015), Innowacyjność na przykładzie kobiet i mężczyzn prowadzq̨cych gospodarstwa rolne z gminy Bojanowo, "Roczniki Naukowe Stowarzyszenia Ekonomistów Rolnictwa i Agrobiznesu", t. 17, z. 5.

61. Gopalakrishnan S. (2000), Unraveling the Links Between Dimensions of Innovation and Organizational Performance, "The Journal of High Technology Management Research", vol. 11(1).

62. Griffin R.W. (1996), Podstawy zarządzania organizacjami, Wydawnictwo Naukowe PWN, Warszawa.

63. Griffin R.W. (2001), Podstawy zarzqdzania organizacjami, Wydawnictwo Naukowe PWN, Warszawa.

64. Grudzewski W., Hejduk I. (2001), Projektowanie systemów zarzq̨dzania, Wydawnictwo Difin, Warszawa.

65. Gruszewska E. (2013), Instytucje nieformalne w Polsce. Krajobraz po transformacji, "Studia Ekonomiczne. Uniwersytet Ekonomiczny w Katowicach", nr 129.

66. Grzega U. (2015), Unowocześnianie konsumpcji gospodarstw domowych, [w:] Zachowania konsumentów. Procesy unowocześniania konsumpcji, E. Kieżel, S. Smyczek (red.), Oficyna a Wolters Kluwer Business, Warszawa.

67. Gutkowska K. (2011), Innowacyjność konsumentów wobec produktów żywnościowych jako warunek rozwoju rynku żywności, "Konsumpcja i Rozwój", nr 1. 
68. Gutkowska K., Kowalczuk I., Sajdakowska M., Żakowska-Biemans S., Kozłowska A., Olewnik-Mikołajewska A. (2014), Postawy konsumentów wobec innowacji na rynku żywności, „Handel Wewnętrzny”, nr 4.

69. Gutkowska K., Żakowska-Biemans S., Dajdakowska M. (2009), Preferencje konsumentów w zakresie możliwych do zastosowania innowacji w produktach tradycyjnych, "Żywność. Nauka. Technologia. Jakość", nr 3(64).

70. Hansen F. (1972), Consumer Choice Behavior. A Cognitive Theory, The Free Press, New York.

71. Hurley R.F., Hult G.T.M. (1998), Innovation, Market Orientation and Organizational Learning: An Integration and Empirical Examination, "Journal of Marketing", vol. 62(3).

72. Innowacyjność przedsiębiorstw - koncepcje, uwarunkowania i pomiar (2014), Kraśnicka T., Ingram T. (red.), Wydawnictwo Uniwersytetu Ekonomicznego w Katowicach, Katowice.

73. Jachnis A., Terelak J.F. (1998), Psychologia konsumenta i reklamy, Oficyna Wydawnicza Branta, Bydgoszcz.

74. Janasz W. (2003), Innowacje i ich miejsce $w$ działalności przedsiębiorstw, [w:] Innowacje w modelach działalności przedsiębiorstw, W. Janasz (red.), „Rozprawy i Studia. Uniwersytet Szczeciński", t. 466.

75. Janasz K. (2009), Kapitał a decyzje innowacyjne w przedsiębiorstwie, "Przegląd Organizacji", nr 10.

76. Janasz W., Kozioł K. (2007), Determinanty działalności innowacyjnej przedsiębiorstw, Polskie Wydawnictwo Ekonomiczne, Warszawa.

77. Janoś-Kresło M. (2006), Konsumpcja jako proces zaspokajania potrzeb; Cechy konsumentów i gospodarstw domowych jako podmiotów konsumpcji; Konsument i konsumpcja we wspólczesnej gospodarce rynkowej, [w:] Konsument i konsumpcja we współczesnej gospodarce rynkowej, M. Janoś-Kresło (red.), Oficyna Wydawnicza Szkoły Głównej Handlowej w Warszawie, Warszawa.

78. Jasiński A.H. (1997), Innowacje i polityka innowacyjna, Wydawnictwo Uniwersytetu w Białymstoku, Białystok.

79. Jasiński A.H. (2000), Innowacje i transfer techniki w gospodarce polskiej, Wydawnictwo Uniwersytetu w Białymstoku, Białystok.

80. Jasiński A.H. (2006), Innowacje i transfer techniki w procesie transformacji, Wydawnictwo Difin, Warszawa.

81. Jaśkowski P. (2009), Neuronauka poznawcza. Jak mózg tworzy umysł, Vizja Press\&IT, Warszawa.

82. Jasiński A.H. (2012), Innowacja, firma innowacyjna, scena innowacji, [w:] Ekonomika i zarzq̨dzanie innowacjami w warunkach zrównoważonego rozwoju, A.H. Jasiński, R. Ciborowski (red.), Wydawnictwo Uniwersytetu w Białymstoku, Białystok.

83. Jodłowska L. (2010), Bariery działalności innowacyjnej MŚP w Niemczech, [w:] Mikrofirma: strategie zarządzania mikro i małymi przedsiębiorstwami, 
"Zeszyty Naukowe" nr 585, Wydawnictwo Uniwersytetu Szczecińskiego, Szczecin.

84. Kalinowski B. (2010), System zarzq̨dzania wspierajacy innowacje, „Ekonomika i Organizacja Przedsiębiorstwa", nr 7.

85. Kalisiak J. (1975), Nowy produkt. Planowanie i organizacja, Państwowe Wydawnictwo Naukowe, Warszawa.

86. Kang J., Park-Poaps H. (2010), Hedonic and Utilitarian Shopping Motivations of Fashion Leadership, "Journal of Fashion Marketing and Management", vol. 14, no. 2 .

87. Kempny M. (2005), Wprowadzenie - Konsumpcja wyzwaniem dla socjologii współczesnej, [w:] Konsumpcja - istotny wymiar globalizacji kulturowej, Wydawnictwo IFiS PAN, A. Jawłowska, M. Kempny (red.), Warszawa.

88. Kiełczewski D. (2012), Różnorodność stylów życia jako czynnik rozwoju zrównoważonego, "Ekonomia i Środowisko", nr 3 (43).

89. Kiełczewski D. (2008), Sektor publiczny w kształtowaniu wzorców trwałej konsumpcji, "Optimum. Studia Ekonomiczne", nr 4.

90. Kiełczewski D. (2005), Style konsumpcji jako przejaw zróżnicowania poziomu życia, "Gospodarka Narodowa", nr 5-6.

91. Kiełczewski D. (2015), Wpływ ekologizacji konsumpcji na zmiany w zarzadzaniu organizacjami, "Handel Wewnętrzny", nr 6.

92. Kieżel E. (2000), Zachowania konsumpcyjne konsumentów i gospodarstw domowych, [w:] Rynkowe zachowania konsumentów, E. Kieżel (red.), Wydawnictwo Akademii Ekonomicznej w Katowicach, Katowice.

93. Kimberly J.R., Evanisko M.J. (1981), Organizational Innovation: The Influence of Individual, Organizational and Contextual Factors on Hospital Adoption of Technological and administrative Innovations, "Academy of Management Journal", vol. 24(4).

94. Kitchell S. (1995), Corporate Culture Environmental Adaptation, and Innovation Adoption: A Qualitative/Quantitative Approach, "Journal of the Academy of Marketing Science", vol. 23(3).

95. Kline S., Rosenberg N. (1986), An overview on Innovation, [w:] The Positive Sum Strategy: Harnessing Technology for Economic Growth, R. Landau, N. Rosenberg (eds.), National Academy Press, Washington.

96. Knap-Stefaniuk A. (2007), Innowacje a konkurencyjność przedsiębiorstw, "Zarządzanie Zmianami", nr 2.

97. Koniorczyk G. (2014), Smart shopping a zachowania zakupowe polskich konsumentów, „Handel Wewnętrzny”, nr 3.

98. Kościelniak H., Brendzel-Skowera K. (2014), Crowdsourcing w zarządzaniu organizacjami, „Zeszyty Naukowe Wyższej Szkoły Humanitas. Zarządzanie", nr 2.

99. Kotarba W. (1987), Organizacja i wynalazczość w przedsiębiorstwie, Zrzeszenie Wojewódzkich Klubów Techniki i Racjonalizacji, Warszawa. 
100. Kotler Ph. (1994), Marketing. Analiza, planowanie, wdrażanie i kontrola, Gebethner i Ska, Warszawa.

101. Kotler Ph. (2005), Marketing, Dom Wydawniczy Rebis, Poznań.

102. Kowalska M. (2015), Wpływ wirtualizacji zachowań konsumenckich na rozwój domocentryzmu, "Handel Wewnętrzny", nr 6 (359).

103. Kozłowska K. (2016), Ocena wybranych aspektów innowacyjności polskich przedsiębiorstw, [w:] Ekonomia i zarządzanie w teorii i praktyce. Ekonomia i nauki o zarządzaniu o warunkach integracji gospodarczej, t. 9, P. Urbanek, E. Wlaińska (red.), Wydawnictwo Uniwersytetu Łódzkiego, Łódź.

104. Krajewski M. (2005), Co dziś konsumujemy? Socjologia przedmiotów, [w:] Konsumpcja. Istotny wymiar globalizacji kulturowej, A. Jawłowska, M. Kempny (red.), Wydawnictwo IFiS PAN, Warszawa.

105. Kramer T. (2004), Podstawy marketingu, Polskie Wydawnictwo Ekonomiczne, Warszawa.

106. Krzykała F. (1975), Wprowadzenie do socjologii przedsiębiorstwa przemysłowego, Polskie Wydawnictwo Ekonomiczne, Warszawa.

107. Kucharska B. (2014), Trendy w zachowaniach konsumentów jako uwarunkowanie innowacji w handlu zagranicznym, "Zeszyty Naukowe Uniwersytetu Ekonomicznego w Katowicach. Studia Ekonomiczne", nr 187.

108. Kwieciński L., Moszkowicz K., Sroka J. (2007), Innowacyjność i internacjonalizacja dolnoślaskich małych i średnich przedsiębiorstw, Wydawnictwo Adam Marszałek, Toruń.

109. Laukkanen T., Sinkkonen S., Kivijärvi M., Laukkanen P. (2007), Innovation Resistance among Mature Consumers, "Journal of Consumer Marketing", vol. 24, No. 7.

110. Lumpkin G.T., Dess G.G. (1996), Clarifying the Entrepreneurial Orientation, Construct and Linking It to Perfermance, "Academy of Management Review", vol. 21(1).

111. Łukasik P. (2008), Marketing w handlu detalicznym produktów spożywczych. Wybrane aspekty zachowań nabywców, Wydawnictwo Uniwersytetu Marii Curie Skłodowskiej, Lublin.

112. Maciejewski G. (2015), Konsument wobec innowacji produktowych, "Logistyka", nr 2.

113. Mały Rocznik Statystyczny (2015), Wydawnictwo GUS, Warszawa.

114. Markiewicz J. (2007), Innowacje, [w:] Innowacyjność w działalności przedsiębiorstw. Kompendium wiedzy, P. Niedzielski, J. Markiewicz, K. Rychlik, T. Rzewuski (red.), Wydawnictwo Uniwersytetu Szczecińskiego, Szczecin.

115. Martinez E., Polo Y., Flavián C. (1998), The Acceptance and Diffusion of New Consumer Durables: Differences between First and Last Adopters, "Journal of Consumer Marketing", vol. 15, no. 4.

116. Maslow A.H. (1990), Motywacji i osobowość, Instytut Wydawniczy PAX, Warszawa. 
117. Matel A. (2015), Konsumpcja umiaru a współczesne trendy zachowań konsumenckich, "Zarządzanie. Teoria i praktyka", nr 3(13).

118. Matel A. (2016), Przesłanki ekologizacji konsumpcji z perspektywy zachowań konsumenckich, "Zarządzanie. Teoria i praktyka", nr 2(16).

119. Matel A., Poskrobko T. (2016), Contingent valuation Method in terms of behavioral economics, "Ekonomia i Środowisko", nr 1(56).

120. Mazurek-Łopacińska K. (2003), Zachowania nabywców i ich konsekwencje marketingowe, Polskie Wydawnictwo Ekonomiczne, Warszawa.

121. Mazurek-Łopacińska K. (2015), Rola kodów kulturowych i zachowań konsumentów w kreowaniu innowacji, "Marketing i Rynek", t. XXII, nr 2, A. Olejniczuk-Merta (red.), Konsumpcja i innowacje.

122. Mierzejewska B. (2008), Open Innovation - nowe podejście w procesach innowacji, „E-mentor", nr 2.

123. Mirow C., Hoelzle K., Gemuenden G. (2008), The Ambidextrous Organization in Practice: Barriers to Innovation within Research and Development, referat z konferencji Academy of Management, Anaheim.

124. Mizgajska H. (2002), Aktywność innowacyjna polskich małych i średnich przedsiębiorstw w procesie integracji z Uniq Europejska, Wydawnictwo Akademii Ekonomicznej w Poznaniu, Prace habilitacyjne nr 4, Poznań.

125. Mróz B. (2013), Konsument w globalnej gospodarce. Trzy perspektywy, Oficyna Wydawnicza Szkoły Głównej Handlowej, Warszawa.

126. Muth J.F. (1961), Rational Expectations and the Theory of Price Movements, "Econometrica", vol. 29, no. 3.

127. Niedzielski P., Rychlik K. (2006), Innowacje i kreatywność, Wydawnictwo Uniwersytetu Szczecińskiego, Szczecin.

128. Nordström K., Biaström M. (2002), Emergence of dominant design in probiotic functional food development, "British Food Journal" vol. 104, no. 9.

129. Nowak L. (1995), Pozaekonomiczne determinanty zachowań nabywców, Wydawnictwo Akademii Ekonomicznej w Poznaniu, Poznań.

130. Osęka M., Wypijewski J. (1985), Innowacyjność przedsiębiorstw. Ekonomiczne i organizacyjne determinanty, Państwowe Wydawnictwo Naukowe, Warszawa.

131. Oslo Manual (2005a), OECD, Paris.

132. Oslo Manual (2005b), Pomiar działalności naukowej i technicznej. Zasady gromadzenia i interpretacji danych dotyczacych innowacji, Wspólna publikacja OECD i Eurostatu, Organizacja Współpracy Gospodarczej i Rozwoju. Urząd Statystyczny Wspólnot Europejskich.

133. Oslo Manual (2008), Pomiar działalności naukowej i technicznej. Zasady gromadzenia i interpretacji danych dotyczacych innowacji, Wspólna publikacja OECD i Eurostatu, Organizacja Współpracy Gospodarczej i Rozwoju, Urząd Statystyczny Wspólnot Europejskich 2005, Wydanie trzecie, polskie: Ministerstwo Nauki i Szkolnictwa Wyższego. Departament Strategii i Rozwoju Nauki, Warszawa. 
134. Patrzałek W. (2014), Konsument wobec wyzwań współczesnych megatrendów, "Handel Wewnętrzny", nr 4(351).

135. Penc J. (1995), Strategie zarzadzania, Agencja Wydawnicza „Placet", Warszawa.

136. Penc J. (1999), Innowacje i zmiany w firmie. Transformacja i sterowanie rozwojem przedsiębiorstwa. Zasady działania. Warunki sukcesu, Agencja Wydawnicza "Placet", Warszawa.

137. Pomykalski A. (2001), Zarządzanie innowacjami. Globalizacja, konkurencja, technologia informacyjna, Wydawnictwo Naukowe PWN, Warszawa-Łódź.

138. Poskrobko B. (2011), Wiedza i gospodarka oparta na wiedzy, [w:] Gospodarka oparta na wiedzy. Materiały do studiowania, B. Poskrobko (red.), Wydawnictwo Wyższej Szkoły Ekonomicznej, Białystok.

139. Poskrobko T., Zielińska A. (2015), Innowacje w krajach rozwijających się a zrównoważony rozwój, "Prace Naukowe Uniwersytetu Ekonomicznego we Wrocławiu", nr 409.

140. Poznańska K. (1998), Uwarunkowania innowacji w małych i średnich przedsiębiorstwach, Dom Wydawniczy ABC, Warszawa.

141. Prandecki K. (2013), Długookresowe zmiany konsumpcji a zrównoważony rozwój, "Handel Wewnętrzny", nr 6A, t. 2.

142. Przewoźna-Skowrońska A. (2015), Innowacyjność konsumentów na rynku dań gotowych wymogiem rozwoju rynku żywności, „Logistyka" nr 2.

143. Raaij van F., Konsumpcja postmodernistyczna, [w:] Zachowanie konsumenta. Koncepcja i badania europejskie, M. Lambkin, G. Foxall, F. Van Raaij, B. Heilbrunn (red.), Wydawnictwo Naukowe PWN, Warszawa 2001.

144. Raport o stanie sektora małych i średnich przedsiębiorstw w Polsce w latach 1998-1999, (2000), Dzierżanowski W., Sztetyłło A. (red.), Polska Fundacja Promocji i Rozwoju Małych i Średnich Przedsiębiorstw, Warszawa.

145. Reinstaller A., Sanditov B. (2005), Social structure and consumption: on the diffusion of consumer good innovation, "Journal of Evolutionary Economics", No. 15.

146. Ritzer G. (2005), Makdonalizacja społeczeństwa, Wydawnictwo MUZA S.A., Warszawa.

147. Rocznik Statystyczny Rzeczpospolitej Polskiej (2006, 2007, 2008, 2009, 2010, 2011, 2012, 2013, 2014, 2015), Wydawnictwo Głównego Urzędu Statystycznego, Warszawa.

148. Rogers E.M. (2003), Diffusion of Innovation, The Free Press, New York.

149. Rogers E.M., Shoemaker F.F. (1971), Communication of Innovations: A Cross-Cultural Approach, Free Press, New York.,

150. Rogoda B. (2005), Przedsiębiorczość i innowacje, Wydawnictwo Akademii Ekonomicznej w Krakowie, Kraków. 
151. Romanowski R. (2013), Ewolucja trendów konsumenckich w XXI wieku w kontekście tworzenia gospodarki opartej na wiedzy, "Handel Wewnętrzny", nr styczeń-luty.

152. Rothwell R. (1994), Towards the Fifth-generation Innovation Process, "International Marketing Review", vol. 11, no. 1.

153. Rudnicki L. (2004), Zachowania rynkowe nabywców. Mechanizmy i uwarunkowania, Wydawnictwo Akademii Ekonomicznej w Krakowie, Kraków.

154. Rudnicki L. (2012), Zachowania konsumentów na rynku, Polskie Wydawnictwo Ekonomiczne, Warszawa.

155. Rychlik K. (2007), Uwarunkowania działalności innowacyjnej, [w:] Innowacyjność w działalności przedsiębiorstw. Kompendium wiedzy, P. Niedzielski i in., Wydawnictwo Uniwersytetu Szczecińskiego, Szczecin.

156. Saviotti P.P., Pyka A. (2016), Innovation, structural change and demand evolution: does demand saturate?, "Journal of Evolutionary Economics", vol. 26.

157. Schumpeter J. (1960), Teoria wzrostu gospodarczego, Państwowe Wydawnictwo Naukowe, Warszawa.

158. Schiffman L.G., Kanuk L.L. (2010), Consumer Behaviour. Global Edition, Pearson Higher Education, London.

159. Sharot T. (2009), Dopamine Enhances Expectation of Pleasure in Humans, "Current Biology", vol. 19, Iss. 24.

160. Shaw F. (2009), Uncertenity and the new consumer, "Foresight", vol. 4.

161. Szwartz B. (2004), Paradox of Choice. Why More Is Less, HarperCollins Publishers, New York.

162. Sitkiewicz K. (2009), Stan pragnienia. Oblicza mac(k)donaldyzacji, Wydawnictwo CeDeWu, Warszawa.

163. Smith D. (2006), Exploring Innovation, The McGrew-Hill Companies, New York.

164. Smoleń T. (2012), Produkt, [w:] Podstawy marketingu, P.A. Czubała (red.), Polskie Wydawnictwo Ekonomiczne, Warszawa.

165. Spruch W. (1976), Strategia postępu technicznego, Państwowe Wydawnictwo Naukowe, Warszawa.

166. Stalk G., Evans P., Shulamnan L.E. (1992), Competing on Capabilities: The New Rules of Corporate Strategy, "Harvard Business Review", vol. 70(3).

167. Strużycki M., Bojewska B. (2011), Rola państwa i rzqdu w kształtowaniu innowacyjnej gospodarki, [w:] Innowacje w rozwijaniu konkurencyjności firm. Znaczenie, wsparcie, przykłady zastosowań, J. Perenc, J. Hołub-Iwan (red.), Wydawnictwo C.H. Beck, Warszawa.

168. Szatkowski K. (2001), Istota i rodzaje innowacji, [w:] Zarządzanie innowacjami technicznymi i organizacyjnymi, M. Brzeziński (red.), Wydawnictwo Difin, Warszawa. 
169. Szczepański J. (1981), Konsumpcja a rozwój człowieka. Wstęp do antropologicznej teorii konsumpcji, Polskie Wydawnictwo Ekonomiczne, Warszawa.

170. Szul E. (2016), Konsumenci wobec innowacyjnych produktów , „Nierówności Społeczne a Wzrost Gospodarczy", nr 46 (2).

171. Światowy G. (2006), Zachowania konsumentów: determinanty oraz metody poznania i kształtowania, Polskie Wydawnictwo Ekonomiczne, Warszawa.

172. Tapscott D. (1999), Growing up Digital: The Rise of the Net Generation, McGrew-Hill, New York.

173. Tidd, J., Bessant, J., Pavitt, K. (2002), Managing Innovation: Integrating Technological, Market and Organizational Change, John Wiley \& Sons, New York.

174. Tkaczyk S., Kołuda J. (2013), Nowe trendy konsumenckie a sukces organizacji, „Zeszyty Naukowe Uniwersytetu Przyrodniczo-Humanistycznego w Siedlcach", seria: Administracja i Zarządzanie, nr 97.

175. Tomczyk A. (2014a), Czynniki wzrostu gospodarczego Polski w latach 20032013 w ujęciu endogenicznych modeli wzrostu, [w:] Ekonomia w ujęciu globalnym, regionalnym i lokalnym, A. Krzysztofek, A. Przybyłka (red.), AT Wydawnictwo, Kraków.

176. Tomczyk A. (2014b), Znaczenie czynników instytucjonalnych dla poziomu przedsiębiorczości w Polsce, [w:] Przedsiębiorczość gospodarcza w Polsce szanse i ograniczenia w dobie wychodzenia z kryzysu, A. Sadowski, A. Wyszkowski (red.), Polskie Towarzystwo Ekonomiczne Oddział w Białymstoku, Białystok.

177. Tyszka T. (2004), Zachowania konsumenckie, [w:] Psychologia ekonomiczna, Gdańskie, T. Tyszka (red.), Wydawnictwo Psychologiczne, Gdańsk.

178. Ustawa z dnia 23 kwietnia 1964 roku. Kodeks cywilny (Dz. U. z 2016 roku, poz. 380 tekst jedn. ze zm.).

179. Ustawa z dnia 2 lipca 2004 roku o swobodzie działalności gospodarczej (Dz. U. z 2004 roku, Nr 173, poz. 1807).

180. Ustawa z dnia 15 stycznia 2015 roku o zmianie ustawy o zasadach finansowania nauki oraz niektórych innych ustaw (Dz. U. z 2014 roku, poz. 1620).

181. Vejlgaard H. (2008), Anatomia trendu, Oficyna a Wolters Kluwer Business, Kraków.

182. Wasilik K. (2014), Trendy w zachowaniach współczesnych konsumentów - konsumpcjonizm a konsumpcja zrównoważona, „Konsumpcja i Rozwój”, nr 1.

183. Weresa M.A. (2014), Polityka innowacyjna, Wydawnictwo Naukowe PWN, Warszawa.

184. Wildowicz-Giegiel A. (2009), Etyczny wymiar konsumpcji w świetle wyzwań XXI wieku, „Optimum. Studia Ekonomiczne", nr 1.

185. Włodarczyk J. (2007), Działalność innowacyjna i jej ograniczenia w polskiej gospodarce, [w:] Innowacje w rozwoju gospodarki i przedsiębiorstw: siły 
motoryczne i bariery, E. Okoń-Horodyńska, A. Zachorowska-Mazurkiewicz (red.), Instytut Wiedzy i Innowacji, Warszawa.

186. Włodarczyk K. (2015), Wirtualizacja konsumpcji polskiego społeczeństwa, „Prace Naukowe Uniwersytetu Ekonomicznego we Wrocławiu", nr 414.

187. Zalega T. (2013), Nowe trendy i makrotrendy w zachowaniach konsumenckich gospodarstw domowych w XXI wieku, „Konsumpcja i Rozwój", nr 2(5).

188. Zalega T. (2015), Innowacje a konsumpcja i zachowania konsumpcyjne - wybrane zagadnienia, "Marketing i Rynek", t. XXII, nr 2, A. OlejniczukMerta (red.), Konsumpcja i innowacje.

189. Zalejski J., Faszczewska K. (2012), Zachowania polskich konsumentów wobec produktów ekologicznych, "Economy and Management", no 3.

190. Założenia polityki proinnowacyjnej państw (1994), Komitet Badań Naukowych, Warszawa.

191. Zastempowski M. (2010), Uwarunkowania budowy potencjału innowacyjnego polskich małych i średnich przedsiębiorstw, Wydawnictwo Uniwersytetu Mikołaja Kopernika, Toruń.

192. Żołnierski, A. (2005), Potencjał innowacyjny polskich małych i średniej wielkości przedsiębiorstw, Polska Agencja Rozwoju Przedsiębiorczości, Warszawa. 


\section{Spis tabel}

Tabela 1. Popytowa i podażowa koncepcja innowacji......................................23

Tabela 2. Podział czynników wpływających na aktywność innowacyjną

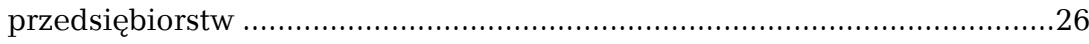

Tabela 3. Bariery wpływające na działalność innowacyjną przedsiębiorstw..............33

Tabela 4. Funkcje innowacyjności konsumentów ...................................................57

Tabela 5. Podstawowe źródła wiedzy o konsumentach w procesie kreowania

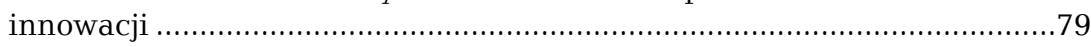

Tabela 6. Internet w poszczególnych fazach procesu decyzyjnego konsumenta.....106

Tabela 7. Wpływ rozwoju sieci internetowej na współczesne trendy zachowań

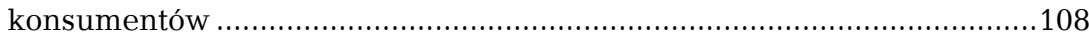




\section{Spis rysunków i wykresów}

Rysunek 1. Podział zewnętrznych źródeł innowacji ..............................................18

Rysunek 2. Podażowy model liniowy innowacji ("pchany przez naukę") ...................21

Rysunek 3. Popytowy model liniowy innowacji (",ciągnięty przez rynek")...................23

Rysunek 4. Model interaktywny procesów innowacyjnych.....................................24

Rysunek 5. Potrzeby wprowadzenia innowacji ..................................................27

Rysunek 6. Determinanty wewnętrzne procesów innowacyjnych

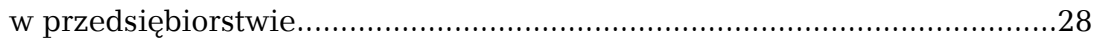

Rysunek 7. Fazy procesu decyzyjnego konsumenta..............................................

Rysunek 8. Proces przyjmowania innowacji przez konsumentów .................................55

Rysunek 9. Interakcje między popytem indywidualnych podmiotów konsumpcji

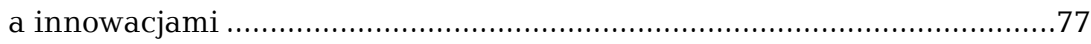

Wykres 1. Gospodarstwa domowe wyposażone w komputer osobisty, w tym z podłączeniem do Internetu w Polsce, w latach 2005-2015..........100

Wykres 2. Zmiana wyposażenia gospodarstw domowych w komputer osobisty w Polsce, w okresie 2005-2015 z podziałem na rodzaje gospodarstw domowych

Wykres 3. Zmiana wyposażenia gospodarstw domowych w komputer osobisty z dostępem do Internetu w Polsce, w okresie 2005-2015 z podziałem na rodzaje gospodarstw domowych.

Wykres 4. Cele prywatnego korzystania z Internetu osób w wieku 16-74 lata w Polsce, w 2015 roku (jako \% ogółu osób w wieku 16-74 lata) 103

Wykres 5. Przedsiębiorstwa wykorzystujące wybrane technologie informacyjnotelekomunikacyjne w Polsce w latach 2005 oraz 2016 104 